San Jose State University

SJSU ScholarWorks

Master's Theses

Master's Theses and Graduate Research

1992

\title{
A comparative study of mid-nineteenth century Chinese blue-and- white export ceramics from the Frolic shipwreck, Mendocino County, California
}

Patricia Hagen Jones

San Jose State University

Follow this and additional works at: https://scholarworks.sjsu.edu/etd_theses

\section{Recommended Citation}

Jones, Patricia Hagen, "A comparative study of mid-nineteenth century Chinese blue-and-white export ceramics from the Frolic shipwreck, Mendocino County, California" (1992). Master's Theses. 471. DOI: https://doi.org/10.31979/etd.263j-ertt

https://scholarworks.sjsu.edu/etd_theses/471

This Thesis is brought to you for free and open access by the Master's Theses and Graduate Research at SJSU ScholarWorks. It has been accepted for inclusion in Master's Theses by an authorized administrator of SJSU ScholarWorks. For more information, please contact scholarworks@sjsu.edu. 


\section{INFORMATION TO USERS}

This manuscript has been reproduced from the microfilm master. UMI films the text directly from the original or copy submitted. Thus, some thesis and dissertation copies are in typewriter face, while others may be from any type of computer printer.

The quality of this reproduction is dependent upon the quality of the copy submitted. Broken or indistinct print, colored or poor quality illustrations and photographs, print bleedthrough, substandard margins, and improper alignment can adversely affect reproduction.

In the unlikely event that the author did not send UMI a complete manuscript and there are missing pages, these will be noted. Also, if unauthorized copyright material had to be removed, a note will indicate the deletion.

Oversize materials (e.g., maps, drawings, charts) are reproduced by sectioning the original, beginning at the upper left-hand corner and continuing from left to right in equal sections with small overlaps. Each original is also photographed in one exposure and is included in reduced form at the back of the book.

Photographs included in the original manuscript have been reproduced xerographically in this copy. Higher quality $6 "$ " 9 9" black and white photographic prints are available for any photographs or illustrations appearing in this copy for an additional charge. Contact UMI directly to order.

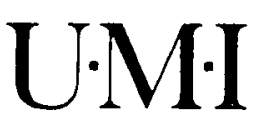

University Microfilms International

A Bell \& Howell information Company 
- 
A comparative study of mid-nineteenth century Chinese blue-and-white export ceramics from the Frolic shipwreck, Mendocino County, California

Jones, Patricia Hagen, M.A.

San Jose State University, 1992 
- - Hemen 


\title{
A COMPARATIVE STUDY OF MID-NINETEENTH CENTURY CHINESE BLUE-AND-WHITE EXPORT CERAMICS FROM THE FROLIC SHIPWRECK, MENDOCINO COUNTY, CALIFORNIA
}

\author{
A Thesis \\ Presented to \\ The Office of Graduate Studies and Research \\ San Jose State University
}

In Partial Fulfillment

of the Requirements for the Degree

Master of Arts

By

Patricia Hagen Jones

December 1992 


\section{APPROVED FOR THE OFFICE OF GRADUATE STUDIES}

Thomes U. Rayton

Dr. Thomas N. Layton, Department of Anthropology

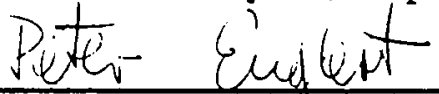

Dr. Peter A. J. Englent, Nuclear Science Facility

a. Seatuk-zuenke

BF. J. A. EnglisbfLueck, Department of Anthropology

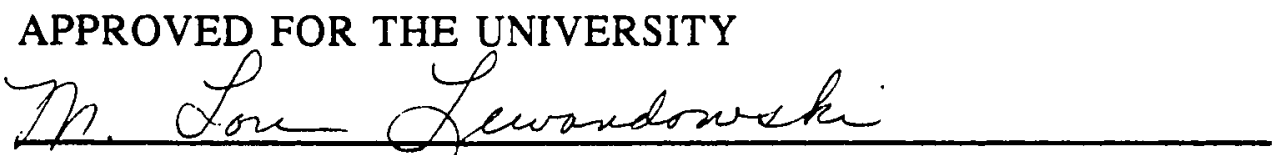




\title{
ABSTRACT \\ A COMPARATIVE STUDY OF MID-NINETEENTH CENTURY CHINESE BLUE-AND-WHITE EXPORT CERAMICS \\ FROM THE FROLIC SHIPWRECK, MENDOCINO COUNTY, CALIFORNIA
}

\author{
by Patricia Hagen Jones
}

The brig Frolic, a former opium runner, sailed from Canton on June 16, 1850 carrying a cargo of Chinese trade goods to California. On this, her only west-to-east trans-Pacific sailing, she ran aground on the Mendocino County coast. Her cargo, including a shipment of Chinese blue-and-white ceramics, thus became part of the archaeological record.

Recovery and acquisition of a large assemblage of the Frolic ceramics has allowed study of stylistic variations among patterns and painters, determination of differences in manufacturing technology, and establishment of a typology. Inquiries through correspondence with archaeologists and scholars around the Pacific Rim and the western United States has yielded information about Chinese ceramics from excavated sites throughout those areas. That information, in combination with examination and analysis of the Frolic ceramics, has made possible the relative dating of similar midnineteenth century Chinese export ceramics and determination of their geographical distribution. 


\section{ACKNOWLEDGEMENTS}

At the beginning I would like to thank my husband, Robert. This thesis could not have been realized without the years of sustained encouragement he has given to me.

Beyond that, a long-time affinity for clay and its properties led propitiously to this endeavor and I thank Dr. Thomas Layton for the timely opportunity to explore a new and challenging aspect of ceramic study. His generosity with his time and resources, and his continued support throughout this undertaking, has made completion of this project possible.

The ceramic samples in this study were gathered by Dr. Layton from ten private collections. It would have been impossible to arrive at a reliable typology without them, and I appreciate the cooperation of all who ultimately donated their collections to this project: David Buller, Steven Buller, Cliff Craft, Louis Fratis, Pat Gibson, Dale Hartesveldt, James Kennon, Patrick Philpot, Larry Pierson, and Paul Selchau.

To the California archaeologists who shared with me their site collections, manuscripts, publications, notes, and knowledge, I am most grateful: Peter Schulz and Larry Felton of the Department of Parks and Recreation in Sacramento; Robert Cartier and Glory Laffey in San Jose; William Roop and Katherine Flynn in Petaluma; and Paul Chace in Escondido.

My particular thanks to those in the Northwest who so generously shared with me their time and resources: Harvey Steele of the United States Customs Service in Portland for spending many, many hours acquainting me 
with Chinese ceramic history; Dr. Daniel Scheans, recently retired from the Anthropology Department of Portland State University, for allowing me to see his extensive collection of Southeast Asian and Chinese ceramics; and Shirley Ganse in Seattle for allowing me to view her slide library and personal ceramic collection.

I am grateful also to Wing $\mathbf{K}$. Leong, Portland artist and master calligrapher, who gave me added insight into the art of Chinese painting. My thanks to Priscilla Wegars for providing me with up-to-date information from the Asian Comparative Collection at the University of Idaho in Moscow, Idaho.

I appreciate the time given to me by the faculty members of San Jose State University: Dr. K. C. Leung, Dr. Stephen Kwan, Dr. Arthur Kao, and Dr. Narae Mochizuki. Their interpretations of Chinese iconography were immensely helpful.

To each of the wonderful people in Australia, New Zealand, the Philippines, Malaysia and elsewhere around the world who answered my inquiries, I am deeply indebted. We are all indeed members of a global village, and I was often overwhelmed at the generosity of spirit that came through in letters from total strangers. My special thanks to Fr. Jesus Antolinez, Peter Bell, R. K. Bhattacharya, Gabriel S. Casal, Ian Crawford, Mark Elvin, Jimmy Foo, John Guy, Annette Hamilton, Chuimei Ho, David Holm, G. M. Jacobs, Wei Ming Jia, Tuton Kaboy, Fiona Leibrick, Alfonz Lengyel, Campbell Macknight, Jack McIlroy, Justin McCarthy, Roxanna 
Ngerntongdee, Barrie Reynolds, Dick Richards, Neville Ritchie, Claire Roberts and Othman Yatim.

My appreciation to Anna Wei for her gracious tutelage in the mysteries of the Chinese language, and to Harvey Steele, Peter Schulz, Thomas Layton and Mary Ann Cook for their editing assistance and recommendations.

Personal thanks to my daughter, Lisa, and good friend, Craig Willson, for guiding me through the perplexities of computerland. Their unfailing patience, technical expertise, and willing good humor were always available throughout my struggle with modern technology to write this document. Finally, thank you to Marcia Morton for her tireless efforts toward putting this document into its final form. 


\section{EPIGRAPH}

And bird-like poise on balanced wing

Above the town of King-te-tching,

A burning town, or seeming so, -

Three thousand furnaces that glow

Incessantly, and fill the air

With smoke uprising, gyre on gyre,

And painted by the lurid glare,

Of jets and flashes of red fire.

Turn, turn, my wheel! What is begun

At daybreak must at dark be done, To-morrow will be another day;

To-morrow the hot furnace flame

Will search the heart and try the frame, And stamp with honor or with shame These vessels made of clay.

Longfellow, Kéramos 


\title{
TABLE OF CONTENTS
}

\begin{abstract}
Page ACKNOWLEDGEMENTS .................... iv TABLE OF CONTENTS $\ldots \ldots \ldots \ldots \ldots \ldots \ldots \ldots \ldots$ viii CHAPTER
\end{abstract}

I. INTRODUCTION $\ldots \ldots \ldots \ldots \ldots \ldots \ldots \ldots \ldots \ldots$

Opening Statement $\ldots \ldots \ldots \ldots \ldots \ldots \ldots \ldots \ldots$

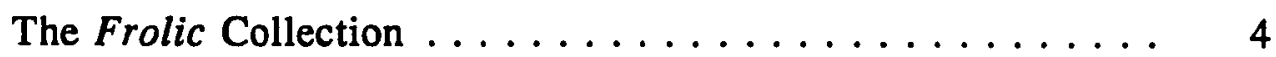

Research Goals ................... 4

II. HISTORICAL PERSPECTIVE: CHINESE CERAMIC HISTORY . . . . . . . . . . . . . . . 9

III. DESCRIPTION AND ANALYSIS $\ldots \ldots \ldots \ldots \ldots \ldots$

Methodology ....................... 15

Production Technology . . . . . . . . . . . . . . . 19

Typology ......................... 21

IV. REVIEW OF SITE COMPARISONS $\ldots \ldots \ldots \ldots \ldots \ldots$

Pacific Rim Historical Sites . . . . . . . . . . . . . 57

Discussion ....................... 66

Selected Western United States Historical Sites ... . . . . 67

Discussion .................... 81

V. CONCLUSION .................. 83

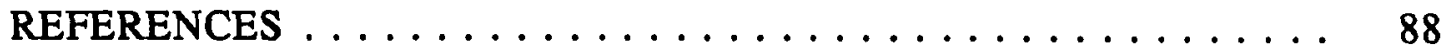

TABLES .......................... 100

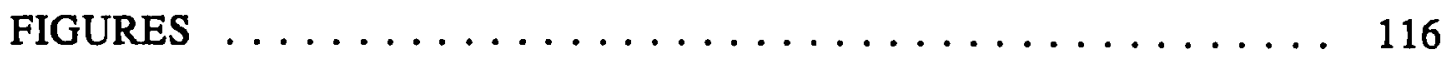

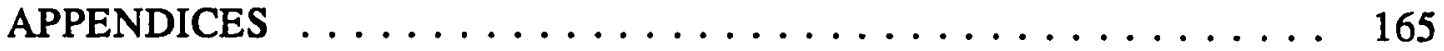

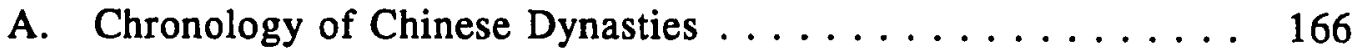

B. Glossary . . . . . . . . . . . . . . . . . . . 167

C. Catalog of Frolic Collection Ceramics . . . . . . . . . 169

viii 


\section{Chapter I \\ INTRODUCTION}

\section{Opening Statement}

On July 26, 1850 the brig Frolic, en route from Canton (Guangzhou) to San Francisco, made a navigational miscalculation and was swept against offshore rocks just north of Point Cabrillo on the Mendocino County coast of California. Her captain and officers reached San Francisco, where an account of their misfortune was published in the Daily Alta California on August 5, 1850 .

When she ran aground, the Frolic took with her a cargo of goods which her captain valued at $\$ 150,000$ (San Francisco prices), including 676 nested stacks and 20 cases of Chinese export ceramics. Some of those ceramics subsequently became a source of raw material from which local Mitom Pomo Indians fashioned beads and tools. Those fragments in turn became part of the archaeological assemblage found approximately 125 years later during excavations at Three Chop Village, a Mendocino County site situated on a ridge linking Mitom home territory (near Willits) with the coast (Layton (1990:177-178). At Three Chop Village (MEN-790), 50 sherds of Chinese porcelaneous stoneware "beilieved to have been salvaged by the Mitom Pomo from the ... Frolic" (Layton 1990:183) were excavated in 1984. The discovery of those Chinese ceramic sherds was the catalyst for the development of a series of linked projects under the direction of Thomas Layton, of which this research is a part. 
By the late 1880s the exact location of the Frolic and her name were forgotten and she had entered the folklore of the coast. However, subsequent to the Three Chop Village excavation, informants revealed that in the 1960s, sport divers rediscovered the remains of the Frolic and, during the 1960s and 1970s, recovered portions of her cargo. At least ten individuals have recovered material from her cargo during these intervening years. Those remains, including the ceramics for this research, have been donated by the divers and are currently stored at San Jose State University where further study of the Frolic cargo is ongoing. Upon completion of that research, all but one of the collections will be placed in the Frolic Shipwreck Repository at the Mendocino County Museum. The remaining collection will be placed at the Kelley House Museum in Mendocino. Oral histories of the divers and their activities relative to the Frolic, together with a full description of the balance of the Frolic's diverse cargo of China trade goods, will be the subject of a future monograph by Layton. That monograph will offer historians a comprehensive picture of the contents of a mid-nineteenth century cargo ship carrying goods from China to America.

In his forthcoming book, Drug Runner, Thomas Layton presents a view into the life of the Frolic, a nineteenth-century brig built in 1844 in Baltimore for the China trade. Her extraordinary speed made her a successful vessel in the fleet of opium clippers plying the waters between India and China prior to her ill-fated trans-Pacific voyage (Layton, pers. comm.).

The Frolic ceramic cargo was intended for the Euro-American and Hispanic population in California prior to the arrival of thousands of Chinese workers during the 1850s. Notices in the June 28 and August 4, 1849 
editions of The Daily Alta California report a shipment of chinaware in the summer of 1849 aboard the ship, Rhone, and in 1850 another shipment of porcelain arrived in San Francisco aboard the brig Eagle from the American China trade firm of Russell and Company (Mudge 1986:190,287).

Table 1 lists by collection catalog number the individuals who donated ceramics for this research, the total number of sherds donated per individual, and the percentage of that number to the total. Since completing this research, three additional collections of Frolic ceramics have been donated, as follows: Larry Pierson, 48 sherds; Vilho Kosonen, 163 sherds; and Kenneth Prewit, 43 sherds. Although these 254 sherds were not included in this research, the typology established prior to their donation remains valid. Additional sherds will likely be recovered when underwater mapping and surface collection is undertaken in the near future.

The Frolic ceramics studied for this research, over 700 sherds of porcelaneous stoneware, have become an important reference collection representing a single commercial event at an instant in time. Furthermore, the collection represents an important benchmark for distinguishing pre-1850 Chinese export ware in California from ceramics subsequently imported for use by Chinese workers after 1850. Because the exact date of the Frolic shipment is known, the comparative cross-dating of other mid-nineteenth century blue-and-white Chinese export ware of the same types, recovered from locations around the Pacific Rim, can be established. 
The Frolic Collection

The Chinese blue-and-white ceramics in the Frolic collection include five abundantly represented types herein referred to as Rocks \& Orchid, Bamboo, Peach \& Fungus, Fu, and Snail (Figures 1, 9, 20, 23, 26, and 29). In addition, five varieties of the Snail type (Figures 32 through 36 ), one unique saucer-plate referred to as Six Treasures (Figure 37), and a blue-andwhite Ginger Jar (Figure 39) are represented. Other less abundant types in the assemblage include relatively small numbers of sherds of brown-glazed earthenware from food storage containers, and several sherds of unknown blue-and-white types (Table 2). Also included in the collection, but not described here, is an assemblage of English Staffordshire transferware sherds, most likely from tableware used by the ship's captain and officers.

Of the 725 specimens of ceramics recovered in association with the Frolic, a total of 656 were determined to belong to five of the seven dominant types. Of that number, 174 or $27 \%$ were vessel bases and were counted as whole vessels or Minimum Number of Vessels (MNV) (Table 2 and 3).

\section{Research Goals}

The focus of this project was to discover where around the Pacific Rim, including the United States West Coast, these same ceramic forms and design motifs were recovered, and to establish the international distribution and chronological placement of these forms.

In order to determine the geographical distribution of these ceramics, contacts were made with museums, archaeological societies and universities in Australia, New Zealand, Malaysia, India, the Philippines, Chile and Peru. 
To accomplish this, letters of inquiry with accompanying photographs of Peach \& Fungus, Bamboo, Rocks \& Orchid, Snail, Fu, and Six Treasures types were sent to curators and directors of museums, professors of archaeology, field archaeologists, private collectors, and recognized experts on Chinese ceramics and archaeology. These individuals were asked to identify those sites in their geographical regions where Chinese blue-andwhite export ceramics, such those in the photographs, had been found. Respondents often forwarded the inquiries to other sources or suggested additional contacts. Informants indicated that there were isolated occurrences of similarity between ceramic types found in Pacific Rim collections and those found in the Frolic collection, often without specific site information. Details of these findings are described in Chapter IV, "Review of Site Comparisons."

Examination of ceramic collections from sites in California and elsewhere in the western United States revealed that although these assemblages are often uniformly homogeneous from site to site, they have little in common with Frolic ware. Indeed, Stenger (1992:5) states that "despite the thousands of nautical miles that separate some of these sites" examination of the ceramic assemblages shows them to be "nearly identical." Further, it is Stenger's observation that the homogeneity of ceramic ware types from "labor intensive ... and primarily male occupied" sites where the dominant occupational activities were railroad construction, mining, agriculture, and canning, may be explained by one of two hypotheses. The first suggests that the Hong system would have "accommodated" those 
leaving China, meaning perhaps that future immigrant workers would have been outfitted with necessities including bowls for eating.

The second hypothesis proposes that shipping company requirements may have included a condition that workers have, in hand, their own eating dishes and "most travelers, not anticipating this mandate, would need to obtain these materials just before boarding . . . . Hence, dock-based sellers of such items would provide a consistent source of supply ...." This consistent supply (of ceramics) could have been ordered from a particular supplier or group of suppliers and could explain the sameness of the assemblages around the Pacific Rim, including the western United States.

Certainly this same argument could be applied to the Frolic ceramic shipment. Is it probable that the shipping company had a contract with a particular ceramic supplier or its Chinese compradore, thus accounting for the types of wares in the assemblage? Almost without exception western United States sites contained examples of Chinese ceramic types known as Double Happiness, Celadon, Four Seasons, and Bamboo, plus smaller quantities of white undecorated earthenware, English transferware, and brown-glazed stoneware. Yet in those same sites, few sherds of Peach \& Fungus or Rocks \& Orchid were recovered, fewer sherds of Fu were seen, and no sherds of Snail were recovered.

A second project goal was the establishment of a typology with a standard nomenclature for the ceramics to facilitate the cross-dating and identification of existing and future collections. For California, the Frolic assemblage is an excellent marker for the end of a style era in Chinese blue- 
and-white export ceramics, representing the last of a pre-Gold Rush genre prior to a change in preferences by new immigrants.

Establishing a typology began with examination of Chinese ceramic decorative types in archaeological assemblages recovered from mid-to-late nineteenth century contexts in the western United States. Analysis of these assemblages revealed that the Frolic collection is different. It includes two decorative types which are only occasionally seen elsewhere (Peach \& Fungus and Rocks \& Orchid), one type which is rarely seen (Fu), and one clearly identifiable type which appears to be unique to the Frolic (Snail). Because these four types are in abundance in the collection, the focus of the research reported here was limited to those types plus Bamboo, which has scant representation in the Frolic collection but is frequently seen elsewhere, both in the western United States and in locations around the Pacific Rim.

Most of the Frolic ware can be identified by the ordinariness of its manufacture. With the exception of Rocks \& Orchid, these ceramics have little in common with their stylistic predecessors. They are relatively coarsely potted and hastily painted and glazed. Underglaze designs are simple, occasionally devolved themes patterned from Ming (1368-1644) and early Qing (1644-1911) motifs. A full discussion of design elements will be presented in in Chapter III, under the section devoted to "Typology."

Commonly used terms to define ceramics similar to the Frolic ceramics include "Overseas Chinese ceramics," "Kitchen Ch'ing [Qing]," "Chinese export ware," "trade pottery," and "Canton or Swatow ware." The designation, "Kitchen Ch'ing," has become a recognized standard due primarily to its use in the definitive publication Nonya Ware and Kitchen 
Ch'ing (Willetts and Lim 1981). That volume, better than any other, sets forth and defines the types and varieties of ordinary Chinese export ware of the late Qing period. (Although literature references cite "Willetts and Poh," the correct attribution is "Willetts and Lim." In keeping with the Asian custom of placing surnames first, the author's full name is Lim Suan Poh [Schulz, pers. comm.].)

As a preface to investigation of the research goals stated above, an overview of Chinese ceramic history will be presented in Chapter II. In Chapter III, a discussion of the methodology used to study the Frolic ceramics is offered, followed by a brief description of traditional ceramic production methods, and a detailed typology. A review of historical sites in both the western United States and the South Pacific is presented in Chapter IV, and a Glossary to assist in clarifying unfamiliar terms is presented in Appendix B.

A note about the use "Canton" rather than its modern name, "Guangzhou." As a place name, Canton is historically familiar, and as a ceramic-ware description, Canton is a common designation, therefore, Canton is used throughout this paper.

In many instances where Chinese terms appear, the older Wade-Giles form is used. These terms are followed, where possible, by the Pinyin form of the word.

Finally, throughout this paper, in order to distinguish the names of the dominant types of Frolic ware from other well-known but non-Frolic ceramics, Frolic types appear in bold face. These are: Rocks \& Orchid, Bamboo, Peach \& Fungus, Fu, Snail, Six Treasures, and Ginger Jar. 


\section{Chapter II \\ HISTORICAL PERSPECTIVE: CHINESE CERAMIC HISTORY}

Chinese tradition holds that blue-and-white porcelain was first developed during the Song dynasty (960-1279) using imported cobalt ore, believed to be from Persia, for the underglaze blue (Yeo and Martin 1978:20; Mudge 1986:17). Centuries of experimentation and refinement led to expanded and sophisticated application of the blue-and-white technology in the Yuan dynasty (1280-1368) until the eventual florescence of the genre in the early Ming dynasty. According to the Chinese writer, Shen Te-fu, potters of that era "were inspired by Heaven to produce works of subtle meaning and supreme artistry" (Burling and Burling 1953:153).

Western historians, while acknowledging that some blue-and-white ceramics do occur prior to the Yuan dynasty, are of the opinion that the technique of applying cobalt directly onto the unfired body of a vessel, rather than onto the glaze, began in the early years of the Yuan dynasty (Mudge 1986:16; Yeo and Martin 1978:24).

Variations in the intensity and richness of the blue underglaze from period to period have made identification of ceramics by period a simpler task (Yeo and Martin 1978:18). During the Chenghua period (1465-1487) of the Ming dynasty, imported cobalt became scarce and therefore expensive. Consequently, local Chinese cobalt was used and mixed with the intensely hued imported cobalt to achieve a softer, more muted blue. Later, during the Jiajing period (1522-1566), imported cobalt known as "Mohammedan blue" 
became available and was used to achieve a deeper and richer blue. After 1566 , local cobalt was again used.

During the Yuan dynasty and throughout the Ming dynasty, the influences of foreign trade created a diverse vocabulary of form and design. It was during this period that the ceramic industry reached its peak and Jingdezhen (Figure 2) became the premier center for the production of not only imperial ware but domestic and export ware as well. Prior to this time, ceramic production was decentralized with location determined by the availability of suitable clay (Yeo and Martin 1978:16). Jingdezhen had a history of ceramic production dating to the Song dynasty and was appreciated as an excellent location because of its proximity to water for transportation, a reliable deposit of clay in local hills, and a plentiful source of wood from nearby forests for firing the kilns (Ganse 1984:6).

Imperial, or "official," porcelain was that category of ceramics made expressly for the reigning emperor and his court. Official porcelain was expected to be "state-of-the-art perfect" (Mudge 1986:14) while domestic and some export ware was allowed to be somewhat less than perfect. Although reign marks did appear earlier, it was not until the Xuande period (14261435 ) of the Ming dynasty that ceramics produced in imperial kilns routinely carried reign marks, and until the reign of Wanli (1573-1620), perhaps only $10 \%$ of those wares actually carried these marks (Steele, pers. comm.). Reign marks generally included the name of the ruling dynasty, the reign title adopted by the emperor, and dates which stated that the piece was made during that reign (Kerr 1986:43; Schulz, pers. comm.). Vessels made in civilian, or private, kilns frequently lacked reign marks. Those destined for 
export were typically without reign marks, though often a reign mark of a prior period might be used, presumably to increase the value of an export product. Prior to the late nineteenth century, with the exception of the Kangxi period (1662-1722), reign marks were usually found enclosed in a double underglaze ring within the foot ring (Kerr 1986:44).

Domestic, or "popular," ware was made primarily for the local market, although this category of porcelain was occasionally exported. Popular ware was produced in private, commercial kilns separate from the imperial kilns, and was generally of good quality, though not of the excellence required for official porcelain. A third category of porcelain, export ware, was produced almost exclusively for foreign clients, often by special order.

Quality and craftsmanship deteriorated toward the end of the Ming dynasty, during the reign of Wanli (Yeo and Martin 1978:32). Guangdong and Fujian provinces south of Jingdezhen became important centers for production, and Amoy (Xiamen) and Swatow (Shantou) became the primary ports of export for those two provinces. "Swatow ware" became synonymous with the roughly potted, inferior ware exported from that port to Japan, India and Southeast Asia (Neave-Hill 1975:151). Much of what is seen in archaeological assemblages from Chinese mining sites is often categorized as "Swatow ware."

Following the reign of Wanli, considered by many to be the "last important period of the Ming dynasty" (Hobson 1976:38), a period of unrest occurred. This interval of turmoil gave rise to the Transitional period (16201683), an era which covers the late Ming and early Qing dynasties. 
The term 'Transitional' thus refers to the period in Chinese ceramic history that witnessed the fall of the Ming dynasty to the Manchus and the consolidation of Manchu control over China under the Qing dynasty. Although politically and socially one of the most chaotic times in Chinese history, it was a period of remarkable achievements in literature, painting, wood-block printing, jade and bamboo carving and ceramics. (Little 1983:1)

Prior to the Transitional period, designs were established by court artists and collected into pattern books for other artists to copy (Fischell 1987:9). However, because these traditional Chinese religious and folk symbols were virtually meaningless to foreigners, potters turned away from the old artistic conventions and adopted new pictorial idioms (Fischell 1987:25).

During the Transitional period, ruling emperors were so preoccupied with warfare that imperial kilns were neglected and court patronage declined (Fischell 1987:25). As a result, potters were free from the rigid style restrictions imposed upon them by the imperial rulers and they soon developed a new iconography to satisfy a growing international market for their wares. This dual source of freedom--court neglect and an increase in European demand--created an environment in which traditional potters could exercise creative artistic expression. Using woodblock illustrated books as inspiration, painters applied narrative themes from Chinese history, mythology, drama and poetry as ceramic decoration (Little 1990:22).

Following the Transitional period, experimentation in new forms and artistic expressions ended and there was a return to traditional pictorial motifs, particularly Ming patterns and designs. During the Kangxi period, elegance of design and beauty of decorative motifs joined to make this another exceptional period in the history of Chinese porcelain (Kerr 1986:58). 
Indeed, "the last great era in the history of Chinese ceramics" occurred during the Qing dynasty and "the zenith of this last period was reached in the eighteenth century" (Medley 1976:240).

During the Yongzheng (1723-1735) and Qianlong (1736-1795) periods the use of reign marks on commercial porcelain was prohibited. As an alternative, eighteenth and nineteenth century clients of wealth had their porcelain marked with artemisia leaves, twin fishes, sprigs of fungus, or pictorial designs, all symbols of good fortune. In addition, commendation marks, potters' signatures, and place marks were used. The latter, place marks, were status symbols referring to specific important rooms in the homes of the well-to-do and aristocracy (Kerr 1986:47). "A great variety of symbols and emblematical devices appear in the porcelain decoration of all periods" including those known as Eight Precious Objects, Eight Immortals (Taoist symbols), The Hundred Antiques, and Eight Buddhist Objects (Hobson 1976:297). These symbols can include musical instruments such as a flute or lyre, a shell, a book, an artemisia leaf, or a sword, to name just a few among a vast variety of symbols, each with its own significance.

Subsequent to the reign of Qianlong, another turbulent period in Chinese political and economic history occurred and the quality of Chinese porcelain once again declined (Yeo and Martin 1978:36). During the early decades of the nineteenth century, as European nations built colonial empires, trade between China and the Western world occurred exclusively through the port of Canton. In 1842, following the end of the Opium War, the Treaty of Nanking granted to Britain the island of Hong Kong as a colony and opened the additional ports of Amoy (Xiamen), Foochow (Fuzhou), Ningpo (Ningbo), 
and Shanghai to Britain. In 1844 , the Treaty of Wanghia formally granted trading rights to the United States. As a consequence of the 1850 Taiping rebellion the kilns at Jingdezhen were destroyed in 1853 (Yeo and Martin 1978:36) and not rebuilt until a decade later (Kerr 1986:123).

This period of conflict between the Manchu rulers of China and the Western colonial powers is reflected in the declining quality of the export ware seen in the Frolic collection and other coeval collections studied for this thesis. 


\section{Chapter III}

\section{DESCRIPTION AND ANALYSIS}

\section{Methodology \\ Type designations used for some Frolic ceramics are from the}

literature. Peach \& Fungus and Fu are well-established names. Bamboo, used here in preference to other familiar designations (Three Circles and Dragonfly, Three Circles and Longevity, Swatow, and Three Friends), is the name traditionally used by the Chinese for this type, and it has become the preferred name in the literature. Ginger Jar, of course, is generic.

Other Frolic types bear unfamiliar names. Rocks \& Orchid is used here in place of the more widely known Rocks \& Bamboo because the central foliage motif has been identified by Chinese informants (A. Wei; Leong; $\mathrm{M}$. Wei; Kao; et al, pers. comm.) as representative of the orchid rather than bamboo. The type designated as Snail is unknown outside this collection. The name is based upon the resemblance of the principal design element to a snail, as confirmed by the above informants. Six Treasures is a temporary designation until future specimens have been recovered and identified.

Prior to determining their types, all ceramics from the Frolic were given a soak in diluted hydrochloric acid to remove calcareous marine growths, followed by a neutralizing soak in a solution of baking soda and water. Each sherd was then cataloged by a primary reference number assigned to each donor, and a specimen number. The ceramics were then segregated according to appearance, with blue-and-white specimens, the focus 
of this study, isolated from all others. Once the sherds had been separated according to types, an attempt was made to assemble complete vessels. This was achieved in only a few instances. A detailed description of the methodology used to determine types and varieties is presented under "Typology."

Of the total 725 ceramic specimens, 503 were assigned to five of the dominant blue-and-white types: Rocks \& Orchid, Bamboo, Peach \& Fungus, Fu, and Snail (Table 3). An additional 153 sherds belonged to those five major types (based upon glaze color and body fabric), but they lacked requisite attributes for specific designation. Of the remaining blue-and-white ceramics, six specimens belonged to two minor types, Six Treasures (a single complete vessel) and Ginger Jar (5 sherds). Eight unique, miscellaneous blue-and-white sherds were set aside and given only cursory study since the primary focus of the research was the principal types referred to above. All of the blue-and-white ceramics will be discussed in detail under "Typology."

Eleven sherds of brown-glazed stoneware were too small for accurate vessel identification or reconstruction. One was possibly a doorknob fragment and six of the remaining sherds were, in all likelihood, storage jar or cooking pot fragments. Those, too, were put aside without further analysis. The four remaining fragments appear to be knops (Figure 3a). These molded forms, also known as knop-handles, appear as ornamental handles on vases and covered vessels and are closely related to ornamental finials which appear on earlier Qing ceramics (Figure 3b). These decorative elements can be traced to the fifteenth century and are known as the "Dog of Fo," a Buddhist guardian lion, or lion-dog (Willetts and Lim 1981:25). 
Thirty-one pieces of English Staffordshire transferware were segregated from the Chinese ware and sorted according to underglaze color and pattern. These sherds were matched for joining, and in two instances large portions of vessels resulted, creating a net count of twenty-eight pieces of Staffordshire ware. Ultimately, the transferware was set aside for future examination because it was not a Chinese export cargo item and therefore not a primary. concern for the present study.

Sixteen ceramic specimens remained to be categorized, and of these, only three could be identified: a finial, a teapot spout, and a small lid.

Vessel measurements (Figure 4) were taken with a standard metric ruler and a caliper. Wherever possible, measurements of specific attributes were taken in at least three locations. Vessel diameters were measured from outside-to-outside of rim edge, and wall thickness measurements were taken $2.0 \mathrm{~cm}$ below the rim (see Table 4 for exceptions). Some vessels, included in the MNV (Minimum Number of Vessels) count, could not be measured because only footrings remained and those were often too abraded for accurate measurement.

Attributes of glaze color, thickness, consistency, and smoothness were considered for each type. Those differences can occur as a result of a number of conditions: inaccurate or inconsistent composition of glaze constituents, poor application technique, variations in firing time and temperature, or the location of the vessel in the kiln during firing.

The intensity of underglaze blue can be affected by the amount and source of cobalt ore used. The smallest amount of cobalt will produce a vivid blue under most conditions. However, the quality of the cobalt, or a 
chemical reaction of cobalt with constituents in the glaze, can alter the color. The blue underglaze on the Rocks \& Orchid and Peach \& Fungus types is a deep, rich blue whereas the blue on the Fu, Snail and Bamboo types is a softer, grayer blue (see Table 5 for color values of underglaze). These differences aided identification of the types.

Body fabric is less important in Chinese ceramics than in the West, where porcelain is generally defined as being vitreous, white, and translucent, and consistency of these attributes is generally associated with quality. Chinese potters, on the other hand, are less interested in translucency or clay color and more concerned with the creativity and craftsmanship of the potter as criteria of quality (Ganse 1984:7).

A uniform clay composition does not appear to exist among the types in this collection. The clay body of Rocks \& Orchid is finer than other types in the collection, and only Peach \& Fungus is as white (Table 5). This attribute aided in identification of the types. The clay bodies of both $\mathbf{F u}$ and Snail are somewhat gray and coarse, although they do not appear to contain as much temper as Peach \& Fungus.

The Peach \& Fungus clay body is neither very fine, nor coarse. There are a number of iron inclusions in the glaze, as well as pit marks resulting from poor glazing technique and bubbling of the glaze during firing. These body fabric and glaze characteristics, in combination with the thin everted rim and contrasting thickly potted base, facilitated identification and isolation of Peach \& Fungus sherds.

There are two major styles of Chinese painting. The first style, Kung$p i$ (Gong bi), meaning "work-brush," emphasizes execution and is historically 
the older method in which forms are "built up of fine brush strokes [and] the work is executed slowly in great detail." Visually, it is a clear, representational style (Leong 1947:7).

The second style, I-pi (Yi-bi), ("idea-brush"), is a newer method called the "free-hand style, or non-outline method. The brush strokes are free, swift, and spontaneous." This style allows for "subtlety, ambiguity, and deep expression" and is consistent with the Chinese preference for depicting the idea or meaning of a subject, rather than emphasizing the form or shape as in Western painting (Leong 1947:7).

The Frolic ceramics were produced during a period of political and social turbulence. That, in combination with the free-flowing style of their design elements, suggests they belong to the $I-p i$ (Yi-bi) method of painting.

\section{Production Technology}

As of 1850 , Chinese domestic pottery production methods had undergone little change since before the Song dynasty. As recently as 1920, the same methods of production that had been used for seventeen centuries were still employed (Lenz 1920:395). In this tradition, a single vessel could pass through as many as seventy hands before it was fired (Neave-Hill 1975:132; Kerr 1986:37; Burling and Burling 1953:153), with each successive step in the process done by one man who did only one specific and specialized task. In a further degree of specialization, factories were often classified according to the shape of the piece they produced. Furthermore, factories could be classified by guild systems wherein one family worked in one factory, or one group of workers formed a guild according to the kind of work they did (Lenz 1920:403-405). 
At the beginning of the process, boats delivered bricks of raw clay (kaolin) to the potteries where the clay was cleaned, sifted and levigated prior to kneading or wedging, in preparation for throwing (Lenz 1920:401-402). One man could repeatedly throw the same type vessel with precise, nearmechanized skill, with little or no deviation in size or shape. Variations in vessel dimensions were often less than five millimeters.

The next stages in the process, painting and glazing, were done with extraordinary precision. Each task in the decorative process was done by an individual artist, and separate components of one design element were often executed by different individuals. Sketching, embossing or engraving, carving, tracing features such as flowers, drawing lines, and painting discrete bits of decorative elements were each separate and specific jobs assigned to a specialist (Kerr 1986:38; Neave-Hill 1975:132; Yeo and Martin 1978:18). Glazing involved yet another craftsman who would either dip each piece, or apply the glaze by blowing it through a bamboo tube (Fischell 1987:8; Lenz 1920:399).

The final step in the process, firing the vessels, was done either in climbing kilns, used by small workshops, or in bee-hive kilns used by large manufacturers. Climbing kilns (Figure 5a), still in use today, have several chambers built up the side of a hill and utilize a principle of heat transfer. The heat travels from the bottom of the kiln to the top by way of a natural draft until the heat is deflected to a flue at the uppermost end of the kiln. The bee-hive kiln (Figure 5b), resembling half a large sphere, has a firebox just inside a sunken front opening, and a chimney at its opposite side. Heat is transferred from the firebox and pulled toward the chimney by draft. A 
similarly shaped kiln, called an egg-shaped kiln, more closely resembles half an egg lying lengthwise on its flat side. This type utilizes the same technology of heat transfer, from a firebox in a large front chamber toward a low rear chamber and tall chimney (Ganse 1984:6-7; Nelson 1966:229; Kerr 1986:39-41).

\section{Typology}

The taxonomic system of analysis used to classify the ceramics in this research was based upon the type-variety-mode system set forth by Smith, Willey and Gifford:

When dealing with the pottery from a single site ... one must first sort the material into ceramic units that are distinct from one another only because each represents a combination of attributes which, when observed together, is separable from some other combination of ceramic attributes....

... The basic working units of analysis are "types," "varieties," and "modes," any one of which may be described in terms of the attributes it embodies....

... A type represents an aggregate of visually distinct ceramic attributes already objectified within one or (generally) several varieties that, when taken as a whole, are indicative of a particular class of pottery produced during a specific time interval within a specific region....

... the ceramic variety [is] the basic unit of analysis, which in due course ... either becomes the type (as the established variety) or one of a number of varieties within the type ....

... mode by our definition is an attribute or cluster of attributes that displays significance in its own right. Modes ... [indicate] their individual behavior in cross-cutting varieties and types through time and space. (Smith, Willey and Gifford 1960:331-335) 
These established criteria were the basis for determining types and varieties for Frolic ware. Fifteen types of blue-and-white Chinese export ware were clearly defined, including five major types represented by numerous individual specimens. Those five types, as previously mentioned, include Rocks \& Orchid, Bamboo, Peach \& Fungus, Fu, and Snail. The Snail type was subdivided into five varieties: A, B, C, D and E (Table 6). Two minor types were identified as Six Treasures and Ginger Jar. The remaining eight sherds were each unique and would have the status of "type" if they were identifiable. They may yet achieve that status in the future.

Type identification began with the initial separation of the blue-andwhite sherds into units with similar attributes of underglaze elements and color. Those groupings were subdivided, as follows, according to:

- design elements, including fragments of flowers, plants and calligraphic symbols

- body fabric, which ranged from fine to coarse porcelaneous stoneware

- base and footring form and depth

- wall thickness

- rim thickness and form.

Ultimately sherds of like underglaze design, and vessel form and size, were isolated and placed into the seven types studied.

Six of the types, Rocks \& Orchid, Bamboo, Peach \& Fungus, Fu, Six Treasures, and Ginger Jar have only a single variety. The seventh, Snail, has five varieties (A, B, C, D, and E), determined by such attributes as body thickness, clay texture, underglaze design, footring form, width of 
bisque band in the well, and size and glaze color of the central medallion in the well.

Modal distinctions in the Frolic collection were not apparent except for the common attribute of color: all types and varieties are blue-and-white. All of the seven types mentioned above are discussed in detail in the following section.

The design motif of one of the eight miscellaneous blue-and-white specimens, a small sherd of Cantonware with the "rain and cloud" border pattern (Figure 6a), can be seen again and again in other collections as a rim design for every conceivable vessel form including jam pots, soup tureens, serving platters, cache pots, bulb trays, tea pots and umbrella stands. Another sherd depicting a cloud pattern (Figure 6b) and a third sherd depicting waves (Figure 6c) are also isolated fragments.

Two blue-and-white sherds, each with a fish motif, are unrelated to any other fragment or type in the collection. One is a carp design (Figure 6d) and the other is a partial catfish design (Figure 6e). The carp, a common element in Chinese painting, has scales whereas catfish are generally depicted with whiskers (S. Kwan, pers. comm.).

An unusual blue-and-white sherd, depicting dragon feet, appears to be a portion of a large plate or platter (Figure 7). In Chinese art, the dragon carries great symbolism and represents "the productive force of moisture" that symbolizes spring and the renewal of nature (Williams 1988:132). Stephen Kwan (pers. comm.) states that the dragon "always flies in clouds and produces rain." In dragon iconography there are many permutations of the creature, and among them are: 
three chief species of dragons; the lung [long], which is the most powerful and inhabits the sky; the $l i[l i]$, which is hornless and lives in the ocean; and the chiao [jiao], which is scaly and resides in marshes and dens in the mountains. (Williams 1988:132)

Vessel counts were achieved by first separating sherds from each vessel type into three categories: basal sherds, body sherds, and rim sherds. If more than $50 \%$ of a base was present, that sherd was counted as a whole vessel. All remaining basal sherds were separated according to whether a depression (created while throwing the vessel) existed in the center of the well or a "nipple" (the small bulge in the center of the base, created during trimming) occurred at the center of the base. Basal sherds with either of these features present also counted as whole vessels. Basal sherds which included rims were counted as basal sherds rather than rim sherds. Rim sherds were those fragments with portions of a rim present, but no base. Body sherds were those fragments which had no part of a base or rim present.

MNV was determined by counting those bases which fit the parameters for whole vessels stated above. True vessel counts for the Snail type and varieties were not possible because defining design elements often were missing from fragmentary rim and body sherds. In addition, badly abraded and fragmentary footrings on the Snail type bases often lacked defining characteristics necessary to establish a variety.

Following is an analysis of the seven major blue-and-white types: Rocks \& Orchid, Bamboo, Peach \& Fungus, Fu, and Snail, plus five Snail varieties. Although the single saucer-plate, Six Treasures, and the fragmentary Ginger Jar are included in this analysis, they are not a primary focus of research at this time. Cross-sections of a vessel, and its named components, plus rim and footring forms are shown in Figure 8. 
Type: ROCKS \& ORCHID (Figure 9)

Total sherd count: 71

Minimum Number of Vessels (MNV): 24

Clay: porcelaneous stoneware

Glaze color: pale, blue-green to blue; transparent (Table 5)

Underglaze color: deep blue (Table 5)

Surface texture: smooth

Form: shallow saucer-dish

Rim: rolled rim (Figure 8)

Footring: rounded (Figure 8)

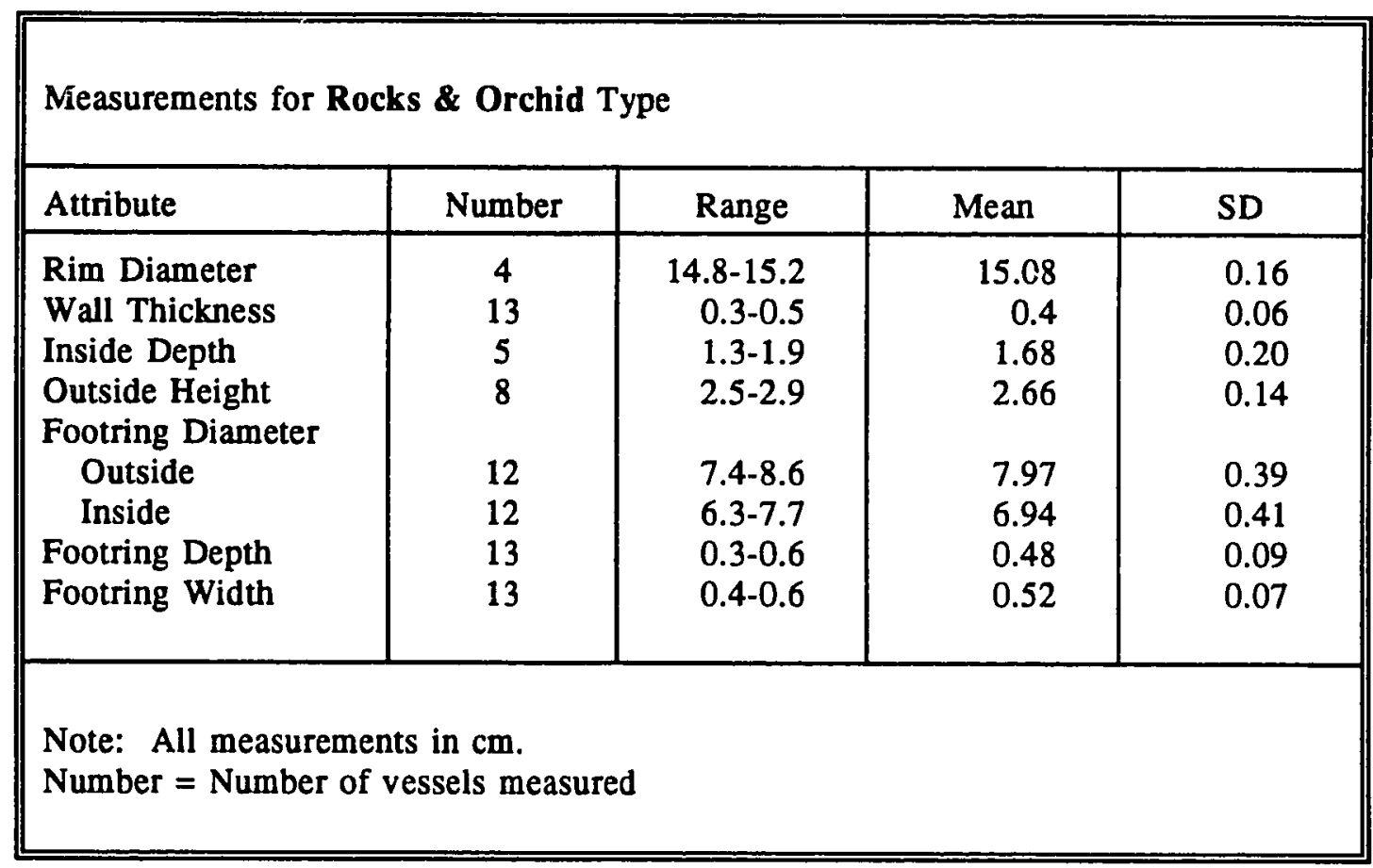

\section{Discussion of Attributes:}

The Rocks \& Orchid design has a long ancestry dating to the Yuan dynasty (Figure 10). It has been produced, with some alteration and devolution, over a period of nearly five hundred years, continuing into the Guangxu reign (1875-1908) of the Qing dynasty and serving "as a striking example of the strength of Chinese tradition" (Garner 1970:52). 
[Saucer-dishes of this type] were made in enormous quantities during the 19th century, and of several grade sizes. The design, highly cryptic, highly condensed, hardly varies. The central element, shaped like a lower-case ' $h$ ' joined to a shorter parallel vertical on its left, could be interpreted as twin trees, as an animal seen in three-quarter view, or as rocaille. (Willetts and Lim 1981:10)

These design elements, along with others which include prunus, pine trees, bamboo, rocks, and tree roots, are the sources from which the Frolic Rocks \& Orchid derives its theme. The entire design of the vessel is devolved from the traditional "Three Friends" trilogy of pine, prunus and rock with bamboo sprouting from it (Figure 11).

Looking at the Rocks \& Orchid saucer-plate, to the left of the central element are two plum or prunus blossoms. Examples of the traditional representation of plum blossoms can be seen in Figure 12a (Leong 1974:55), and on an early Qing ginger jar in Figure 12b (Yeo and Martin 1978:244).

The plum, peony, lotus, and chrysanthemum are symbolical of the four seasons, [with] the plum being the emblem of winter .... It is commonly regarded as a symbol of long life. (Williams 1988:331)

Because it is a hardy plant which blooms in the winter in Northern China, the plum is a symbol of physical strength and strength of character. In keeping with this symbolism, Chinese cultural mythology teaches that the Chinese personality or character developed in Northern China and migrated south (A. Wei, pers. comm.).

The central element of the motif is a rock, or group of rocks, with foliage sprouting from it. This foliage, as executed in the Frolic examples, has the same characteristics as the traditional Chinese representation of orchid, "the emblem of love and beauty, and stands for fragrance and 
refinement . .." (Williams 1988:301). Most informants (Leong; A. Wei; Kao; et al) identified the Frolic Rocks \& Orchid foliage as orchid, rather than the more traditional bamboo. These representations of orchid and bamboo (Figure 13a,b) illustrate the difference between the two motifs and emphasize the rationale for naming this type Rocks \& Orchid.

To the right of the central element is a stylized chrysanthemum, also known as the China aster. "The [chrysanthemum] flower is an emblem of mid-autumn and a symbol of joviality" (Williams 1988:69). This design on export ware to the Middle East and Europe is often called the "aster pattern" (Kerr 1986:62).

The clear glaze has a pale blue-green tinge and the deep, rich blue underglaze appears almost black on some vessels. A narrow band of blue encloses the central design motif at the juncture of the cavetto and the well, and a second band occurs just inside the rim edge. Study and analysis of the design motifs found on the well and cavetto show that although they appear to be uniform, variations occur in the execution of the individual design elements. Figures 14 through 17 illustrate variations of the orchid, chrysanthemum, plum or prunus, and rock, respectively. The numbers accompanying these illustrations represent the catalog numbers of the vessels on which the designs appear. A further discussion of these elements can be found in Table 7.

On the reverse, another narrow band of blue surrounds the rolled rim. Below that band are three equidistant figures which appear to be small boats. Figure 18 illustrates variations of this design detail. Two narrow bands of blue surround the juncture of the footring and the shoulder, and within the 
footring is another narrow blue band. Table 8 offers additional commentary on the exterior wall and base of this vessel.

Centered within the underglaze band within the footring of each vessel is a Chinese character. The significance of these characters is unclear. They represent either the names of kilns (factories) where the vessels were produced or the names of shops where the painting and glazing was done or perhaps the names of family guilds. Figure 19 offers a chart of such characters. The corresponding numbers refer to the catalog numbers of the vessels on which the characters appear. Chinese informants who could read and interpret these characters agreed on their general meaning, however, the underlying subtleties of the Chinese language caused slight variations in translation, all of which are presented in Table 9.

The way of Chinese painting, the Tao, involves an ancient convention and tradition about painting. "Training in brushwork and knowledge of the symbolism" were essential elements in the education of Chinese painters, coupled with an understanding of "the close relationship between painting and calligraphy ..." (Sze 1959:5-6).

The concept of Tao, the ideal of conduct and thought expressive of Tao [was of] fundamental importance, governing technique, theory, and the attitude of the painter....

In Chinese, a single character or combination of two or more characters to form a word depicts an object, act, or thought with a vividness possible only in pictographic writing. Associated ideas contribute overtones of meaning and greatly enlarge the import of the words. (Sze 1959:8) 
In spite of these clear conventions and attitudes toward painting, the "associated ideas [which] contribute overtones of meaning" could very well be the underlying cause of difficulty in trying to interpret with precision the meanings of characters and ideograms on the reverse of Rocks \& Orchid type vessels. 
Type: BAMBOO (Figures 20 and 21)

Total sherd count: 35

Minimum Number of Vessels (MNV): 10

Clay: porcelaneous stoneware

Glaze color: clear, gray-blue (Table 5)

Underglaze color: deep blue; black (Table 5)

Surface texture: uneven glazing; pitted glaze; protruding temper

Form: rice bowl

Rim: rolled (Figure 8)

Footring: deep and thin; rounded (Figure 8)

\begin{tabular}{|c|c|c|c|c|}
\hline \multicolumn{5}{|c|}{ Measurements for Bamboo Type } \\
\hline Attribute & Number & Range & Mean & SD \\
\hline $\begin{array}{l}\text { Rim Diameter } \\
\text { Wall Thickness } \\
\text { Inside Depth } \\
\text { Outside Height } \\
\text { Footring Diameter } \\
\text { Outside } \\
\text { Inside } \\
\text { Footring Depth } \\
\text { Footring Width }\end{array}$ & \begin{tabular}{c}
1 \\
8 \\
\hdashline 3 \\
\hdashline \\
9 \\
9 \\
11 \\
11
\end{tabular} & $\begin{array}{r}12.2^{*} \\
0.40 \\
--.- \\
5.7-6.0 \\
\\
5.6-6.1 \\
4.9-5.4 \\
1.0-1.3 \\
0.3-0.45\end{array}$ & $\begin{array}{r}0.40 \\
0 .- \\
5.87 \\
\\
5.93 \\
5.62 \\
1.10 \\
0.37\end{array}$ & $\begin{array}{r}-- \\
0 \\
\cdots .12 \\
0.16 \\
0.17 \\
0.10 \\
0.04\end{array}$ \\
\hline $\begin{array}{l}\text { Note: All measure } \\
\text { Number }=\text { Number } \\
\text { * Estimated measur }\end{array}$ & $\begin{array}{l}\text { in } \mathrm{cm} \text {. } \\
\text { isels meas }\end{array}$ & & & \\
\hline
\end{tabular}

\section{Discussion of Attributes:}

The design motifs seen on this rice bowl are frequently referred to in the literature as Three Circles and Dragonfly, Three Circles and Longevity, Swatow, and Three Friends. The Chinese themselves referred to this design in inventory lists as Bamboo (Sando and Felton 1987:14), a designation that 
is gradually being adopted as the type name, both in the United States and in the South Pacific. For this reason, Bamboo is used here.

Although there are no complete specimens of Bamboo in the Frolic collection, enough vestiges of the decorative elements of bamboo, dragonfly, three circles, and prunus are apparent for identification of this vessel type. Almost without exception, the patterns on bowls outside the Frolic collection contain at least one group of three circles as part of the design, along with an insect-like element which resembles a dragonfly. Chace (1976:523) describes the complete motif as having four parts: "three circles, the dragonfly character, a marsh with five big leaves, and a flowering plant with four wide leaves, in counter-clockwise order." In his research at Weaverville, Brott (1982b:46) refers to this pattern as including a "stylized marsh [and] what appears to be a flying insect ...." This supports Chace's description and A. Wei's speculation (pers. comm.) that this element may be a dragonfly.

Some researchers are of the opinion that the so-called dragonfly is calligraphy, and others that it is a mushroom. Brott (1982b:54) cites Praetzellis and Praetzellis as indicating that the dragonfly is a stylized ling zhih (ling zhi) or "divine fungus." Further, Brott writes:

While the author would happily support this notion, with the added theory that 'divine fungus' usually refers to a species of consciousness-altering mushroom ... [there] is nothing in the Moon Lee One collection to support any of this. The swamp pattern on the side of the bowls does look like stylized vegetation, and the three circles are usually just that, and the dragonfly resembles a large flying insect more convincingly than it does a mushroom or cursive calligraphy. (Brott 1982b:54)

Those vessels which contain enough of the well to hold a design element have, in keeping with the Chinese tradition of filling empty spaces, what 
appear to be hastily executed random dots, circles and dashes, most likely for the purpose of filling the void. The only other element on the inside of each vessel is a double band where the cavetto joins the well, usually 3.0 to 3.5 $\mathrm{cm}$ below the rim. A single band is just inside the edge of the rim.

Rims are sharply turned outward and uniformly thinner than the bodies of the vessels. All rim sherds have a single band of underglaze on both inside and outside surfaces of the edge, just at the curve of the rim.

On the outside, the bases have a double band of underglaze at the juncture of the foot and the shoulder. Four samples have a double band of underglaze at the shoulder and the remaining samples have but a single band at the shoulder.

The footrings are uniformly deep, usually 1.0 to $1.3 \mathrm{~cm}$ inside and out. This feature easily distinguishes this vessel from other types in the collection. With the exception of the Peach \& Fungus, no other vessel has as deep a footring.

Although the clear, transparent glaze is pale gray-blue, this type has been seen with a light green-blue color in the Ventura, California collection (Chace 1976:523). Variations in underglaze color range from a pale, washedout blue, to an intense blue, to nearly black. The latter is possibly the result of too heavy an application of cobalt or the addition of manganese oxide to the cobalt (Parmalee 1951:283).

The clay body appears more porous than that of other types in the collection. Many of the vessels show small air bubbles and fractures in the clay body, and some have considerable amounts of temper. 
Bamboo type bowls in the Frolic collection are larger than those seen in other site collections (ranging 6.0 to $6.6 \mathrm{~cm}$ rim diameter in Ventura; $6.8 \mathrm{~cm}$ rim diameter in Tucson, for example). Chace (1976:523) discusses two shapes for this type, one with "squared-off" shoulders and abruptly angled sides such as those recovered from the Riverside, California site (Mueller 1987:281) and the other with smooth, curved shoulders and a fluid, continuous line from base to rim. Vessels in the Frolic collection are examples of the latter curved-shoulder variety, found in early post- 1850 California sites. Pastron (1981:666) illustrates two rice bowls of this type in his monograph Behind the Seawall, in which he discusses the excavation of the San Francisco waterfront. Sixty-one vessels of the Bamboo type were recovered from the site, along with 22 rim sherds and 8 body sherds. The illustrated bowls carry the customary design elements of rock, dragonfly, bamboo, and three circles.

Chace describes vessels recovered from Chinese worker camps near Donner Pass, in the California Sierra Nevada mountains, as having "curved, unshouldered sides" (1976:523). A Walnut Grove bowl more closely resembles later post-1850 forms referred to by Chace as the "straight-sided, angular type" (Chace 1976:523). Both the curve-shouldered variety and the straight-sided variety occur in the Tucson collection (Lister and Lister 1989:49; Chace 1976:523). Twenty-five Bamboo bowls were found at Moon Lee One in Weaverville. The report illustrates both the straight-sided and curve-shouldered varieties (Brott 1982b:47).

Although specimens of Bamboo in the Frolic collection are fragmentary, it is possible to see that the bowls are well formed. Variations found at other 
sites may represent stylistic preferences based on individual potting techniques, different pottery manufacturing locations in China, or temporal evolutions in style.

Translations of calligraphic symbols within the bases of seven specimens (Figure 22) in the Frolic collection appear in Table 10. 
Type: PEACH \& FUNGUS (Figure 23)

Total sherd count: 145

Minimum Number of Vessels (MNV): 44

Clay: porcelaneous stoneware

Glaze color: clear; very pale blue (Table 5)

Underglaze color: deep blue (Table 5)

Surface texture: uneven glazing; pitted

Form: large rice bowl

Rim: everted (Figure 8)

Footring: thin walled and deep; rounded (Figure 8)

\begin{tabular}{|l|l|r|r|r||}
\hline \multicolumn{5}{||l||}{} \\
\hline Attribute & Number & Range & Mean & SD \\
\hline Rim Diameter & 1 & 15.5 & 15.5 & 0 \\
Wall Thickness & 4 & $0.3-0.4$ & 0.34 & 0.05 \\
Inside Depth & 2 & 5.7 & 5.7 & 0 \\
Outside Height & 4 & $7.2-7.7$ & 7.38 & 0.19 \\
Footring Diameter & 3 & $6.4-6.7$ & 6.6 & 0.14 \\
Outside & 3 & $5.9-6.2$ & 6.03 & 0.12 \\
Inside & 4 & $1.2-1.4$ & 1.73 & 0.07 \\
Footring Depth & 4 & 0.3 & 0.3 & 0 \\
Footring Width & & & \\
\hline \\
Note: All measurements in cm. \\
Number = Number of vessels measured
\end{tabular}

\section{Discussion of Attributes:}

The design motif of this large, well-shaped rice bowl is similar to both a Kangxi period bowl with a complex interlocking floral design (Figure 24a) and a late twentieth century bowl featuring devolved elements of the peach and fungus motif (Figure 24c). Two further examples of this nineteenth century pattern can be seen in Figure 24b. Referred to as "immortals' fungus birthday congratulations bowls" or simply "birthday bowls" by Willetts and 
Lim (1981:12), the two principal design elements are a stylized peach blossom (t'ao [tao]) and a fungus (ling zhih [ling zhi]). Two tiers of these alternating longevity symbols completely cover the outside of the bowl, with ten units or panels on the top tier, and eight units below. A single, narrow band separates the tiers and each design element is separated by an elongated "s"-shaped line. The peach blossom appears as an arrangement of four blue cotton-like puffs attached to a short, woody stem, and the fungus is a stylized set of blossoms attached to a wispy stem.

A narrow double band of blue surrounds the footring at the juncture of the footring and the base. The footring is small in diameter, narrow in wall thickness, and quite deep, giving this bowl an elegant appearance. Just inside the footring is another double band of blue surrounding a central calligraphic character (Figure 25) which appears to be either a stylized signature or a hallmark, though more likely the latter. The same mark appears on all the bases and basal sherds. It is a double-lined concave-sided square which frames a series of parallel hatch marks running from point to point within the square. Two to three shorter hatch marks appear at right angles to the parallel hatch marks, at opposite points of the square.

Examination of this vessel led one informant (Kai-Cheong Leung) to comment that the character on the base is simply a design used to fill the space. Arthur Kao, on the other hand, feels that these marks are trademarks, and Stephen Kwan indicates that the marks may be a logo for a shop or kiln. Since the same mark appears on all of the 69 Peach \& Fungus type bases and basal sherds in the collection, the latter opinion seems the most plausible. 
Just at the edge of the bowl rim, a single band of underglaze is placed so that during firing it bled slightly over both inside and outside surfaces. Inside the bowl, in the cavetto, a narrow double band of blue encircles the well.

A single stylized fungus is centered in the well (Figure 23). Informant Wing K. Leong, an artist and teacher of Chinese art and calligraphy, states that the figure could be a firefly. Informant Wei Ming Jia, on the other hand, calls both the outside basal mark and the inside well element "flowers and grass," yet asserts that the mark on the base is "not a Chinese mark." These observations serve to further illustrate the ambiguities in interpretation of Chinese art and calligraphy. 


\section{Type: FU (Figure 26)}

Total sherd count: 64

Minimum Number of Vessels (MNV): 14

Clay: fine-grained porcelaneous stoneware (Table 5)

Glaze color: clear; gray (Table 5)

Underglaze color: gray-green to gray-blue

Surface texture: smooth; pitted; iron inclusions

Form: large bowl

Rim: rounded (Figure 8)

Footring: wide and angled

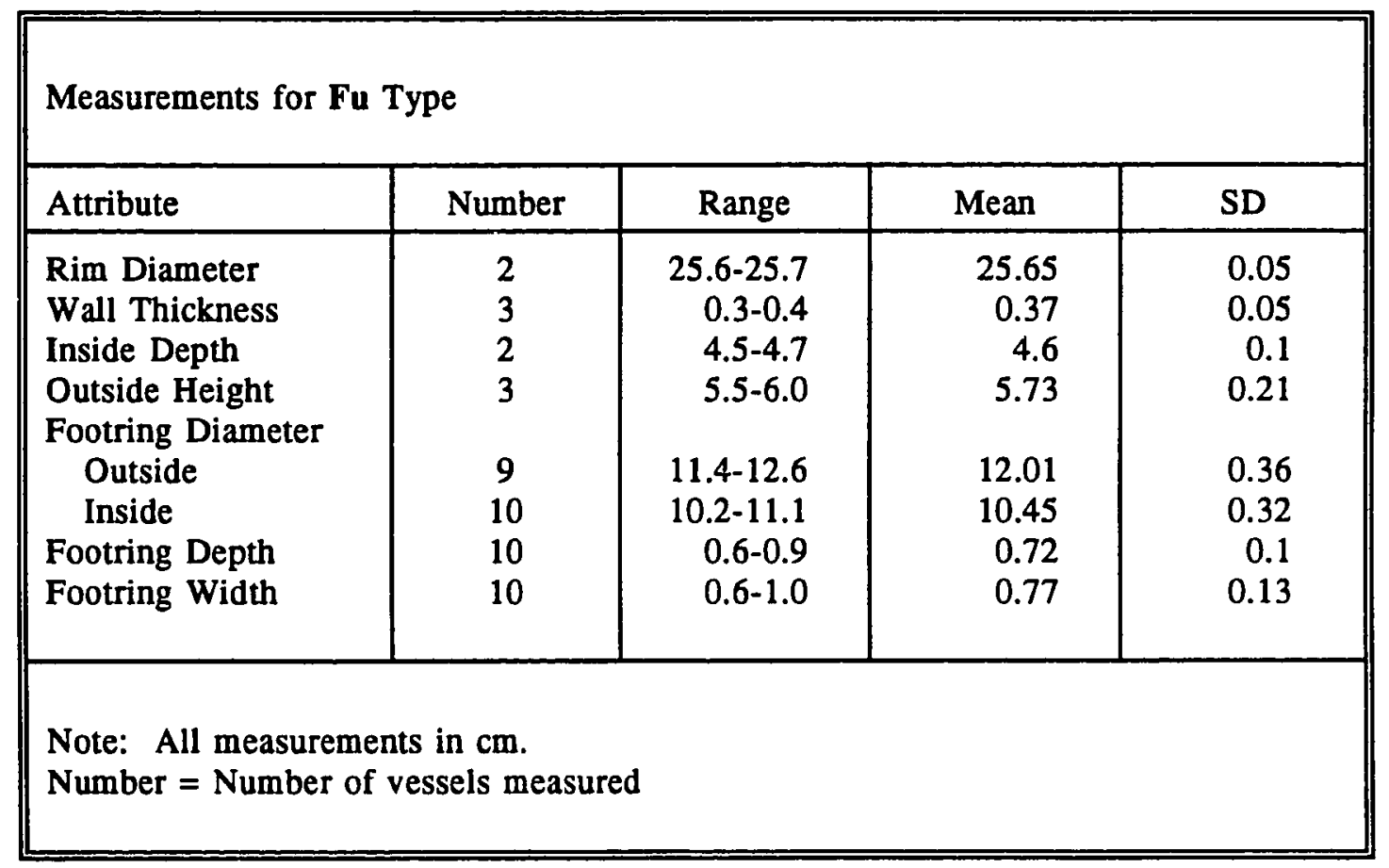

\section{Discussion of Attributes:}

The collection contains one nearly complete example of this type, a large bowl with a central medallion containing the Chinese $f u$ or happiness character. The vessel has two halves which are joined, and which appear to have weathered under two different underwater environments.

A wide bisque band $(1.6 \mathrm{~cm})$, or stacking ring, surrounds the central medallion. The inner portion of the stacking ring is white as a result of 
oxidation of that portion of the ring contained within the circle of the footring of the vessel resting on top during firing. (A unique feature of this particular vessel, but not of the type, is the coloring of the two halves of the bowl, which reflects the uneven weathering referred to previously. One-half of the bisque band is darker and contains multiple iron inclusions).

On the cavetto, a single band ( $0.2 \mathrm{~cm}$ wide) of gray-green underglaze is just below the edge of the rim. A double band of underglaze appears closer to the well, approximately $5.0 \mathrm{~cm}$ from rim edge. Within this space, on opposite walls, are two large, boldly executed, abstract design elements. Unfortunately, two large sections of the cavetto are missing, one from each side, with the same portion of design missing from each side. Similar design elements (Figure 27) can be seen in examples from the Southeast Asian Ceramic Society exhibition (Willetts and Lim 1981:82).

The $f u$ character, in blue-gray underglaze, is centered in the medallion of the well, encircled by a single band of blue-gray underglaze. The character is the same as that on all Fu sherds in the collection, although some are less well executed than others. Figure 28 illustrates examples of variations of this popular Chinese character seen on sherds found in the Frolic collection.

On the reverse, the underglaze banding is inconsistent. Only three samples have sufficient wall remaining to determine the banding pattern. The most complete, \#6-23, has three bands on the outside, as does \#10-66. The third, \#6-24, has only a single band at the rim and a single band at the footring. 
Type: SNAIL (Figure 29)

Total sherd count: 188

Minimum Number of Vessels (MNV): 82

Clay: porcelaneous stoneware

Underglaze color: blue (Table 5)

Surface texture: rough; partial bisque

Form: soup plate

Rim: fully rounded (Figure 8)

\section{Discussion of Attributes:}

The Snail type is subdivided into five varieties: A, B, C, D and E. The varieties are based on:

- placement and design of underglaze motifs on the cavettos

- arrangement of underglaze bands on the cavettos and outside walls

- footring treatment

- body thickness

- glaze application.

All varieties are approximately the size of a contemporary American soup plate, ranging from 17.2 to $18.0 \mathrm{~cm}$ in diameter. They are generally well formed, although hastily potted, as seen by the ridges of clay (created during the potting process) remaining in the bisque or stacking rings of the wells. On all varieties, rough residual rings of fired clay can be seen in these same bisque areas. These rings are a result of fusing, during firing, of nested vessels (which then must be pried loose from one another, thus leaving a ridge of fired clay adhering on the upper surface of the lower vessel). In addition, within this area two color variations often occur as the result of a reducing atmosphere within the footring of a nested pot. 
Significant variations in potting technique, and underglaze and glaze application, lead to the conclusion that several potters and painters were employed in the production of the Snail varieties. Although, at first glance, these vessels appear to be the same or similar, careful examination of the attributes permitted establishment of varieties.

Ten broken fragments of Snail bases have unusual marks on the inside surfaces, incised into the clay while it was still wet (Figure 30, Table 11). The marks are evident on Varieties A, B, and E, and were possibly used to tally stacks of vessels. In addition, two sherds of the Fu type carry these marks.

Othman Yatim of the National Museum in Kuala Lumpur wrote that the incised marks were possibly "a kind of signature or identification of the individual potters" (pers. comm.). While writing his letter, Mr. Yatim had an unscheduled visitor, Mr. Huang Hanjie, from the Fujian Historical Relics Appraisal Committee of China. Mr. Huang agreed with that opinion of the incised marks.

On the other hand, John Guy of the Victoria and Albert Museum in London wrote that he had conferred with Rose Kerr (author of Chinese Ceramics: Porcelain of the Qing Dynasty 1644-1911) about the marks, and she commented that they probably refer to the Chinese numbers "1," "2," and "5." This would agree with the characters as written by A. Wei in Figure 30, although her Chinese character for " 5 " is less devolved than that in the example (Figure 30c). Those seen in Figures 31a and 31b lend further support to the argument that these are numbers (Glathe 1932:4,9). The "5" in Figure $31 \mathrm{~b}$ is in Hua-Ma script, a simplified style used in accounting, 
merchandize inventories, and warehouse tallies (Schulz, pers. comm.) and essentially identical to the mark in Figure 30c.

These differing opinions are not necessarily contradictory. "The kilns were often owned and operated independently of various studios or factories that produced the ceramics. . . . In such circumstances, it would not be surprising to see some sort of identifying marks in use" (Schulz, pers. comm.).

The total number of sherds for the Snail type is 188 , including $82 \mathrm{MNV}$. A breakdown of the number of sherds for each of the five varieties has been established, but the accuracy is open to discussion because of a number of factors:

1. An additional two MNV may be Variety A. Although one base is covered with concretion material, the footring indicates it could be Variety A, $\mathrm{B}$ or $\mathrm{C}$. The other base is a fragment which contains a central depression and "nipple," but the variety cannot be determined. Both of these bases must be included in the MNV for the Snail type but cannot be assigned to a specific variety.

2. To arrive at the total sherd count for the Snail type, 19 of the $\mathbf{5 6}$ basal sherds may be Variety A, and the balance (37) of the basal sherds may be either Variety B or C. These fragments are too water-worn or abraded to identify with accuracy.

3. Of the 11 body sherds, 10 may be Variety $A$, and one is an unknown variety. The body sherds are either too small or have insufficient design elements present to identify with accuracy. 
4. Of the 39 rim sherds, 17 are Variety A. The variety of the remaining 22 cannot be identified with accuracy.

Because of the multiple combinations of attributes among the Snail varieties, each variety is discussed individually. 
Snail, Variety A (Figure 32)

Total Sherd Count: 28

Minimum Number of Vessels (MNV): 11

Glaze Color: semi-opaque; very pale blue (Table 5)

Footring: clean, sharp, and well-trimmed; shallow depth (Figure 8)

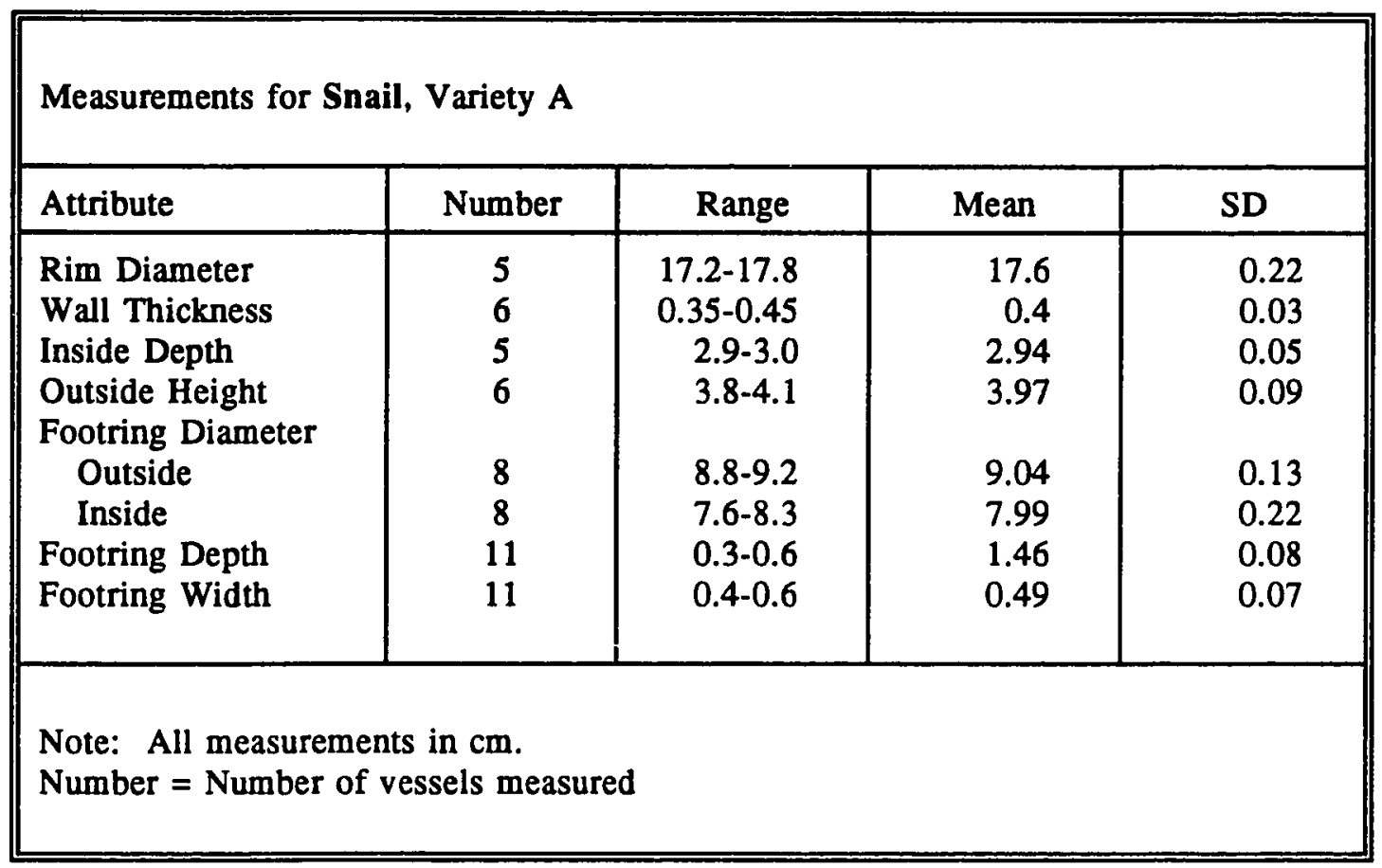

\section{Discussion of Attributes:}

The interior surface of Variety A has four sharp, well-executed design elements on the cavetto: two stylized snails on opposing sides of the cavetto, alternating with two abstract elements. Leong (pers. comm.) states that these latter elements could represent snail tracks.

The center of the well holds a small ring of underglaze averaging $0.6 \mathrm{~cm}$ width. The outside diameter of that ring is $2.9 \mathrm{~cm}$, and it is, in turn, covered with a large circle of glaze. Surrounding that glazed center is a wide band of bisque, left unglazed to allow stacking during firing. A ridge of clay at the 
outer edge of the well is consistent with a feature created while widening the well during potting. A single band of blue underglaze encircles the well just at the juncture of the well and the cavetto, and a second band appears just inside the rim at the top of the cavetto.

The central glazed circle appears to have been hastily applied, as though with a single twist of a brush in a circular movement, and the glaze on the cavetto appears to have been applied by dipping. The glaze stops short of covering the underglaze band of the cavetto and, on some vessels, fails to cover a portion of the design element. Those portions of underglaze left unglazed are dark brown as a result of oxidation during firing.

On the reverse a single band of blue underglaze encircles the vessel just below the rim, and a second, narrower band rings the juncture of the wall and footring. 
Snail, Variety B (Figure 33)

Total Sherd Count: 10

Minimum Number of Vessels (MNV): 10

Glaze: pale blue-green (Table 5)

Footring: clean, sharp, and well-trimmed; shallow depth (Figure 8)

\begin{tabular}{|c|c|c|c|c|}
\hline \multicolumn{5}{|c|}{ Measurements for Snail, Variety B } \\
\hline Attribute & Number & Range & Mean & SD \\
\hline $\begin{array}{l}\text { Rim Diameter } \\
\text { Wall Thickness } \\
\text { Inside Depth } \\
\text { Outside Height } \\
\text { Footring Diameter } \\
\text { Outside } \\
\text { Inside } \\
\text { Footring Depth } \\
\text { Footring Width }\end{array}$ & $\begin{array}{c}-. \\
\cdots \\
\cdots- \\
-- \\
5 \\
5 \\
10 \\
10\end{array}$ & $\begin{array}{r}\cdots-. \\
\cdots-. \\
\cdots-. \\
--. \\
8.5-8.7 \\
7.2-7.7 \\
0.4-0.6 \\
0.4-0.6\end{array}$ & $\begin{array}{l}\cdots-. \\
\cdots-. \\
\cdots-. \\
\cdots \\
8.6 \\
7.5 \\
0.5 \\
0.5\end{array}$ & $\begin{array}{l}\cdots-- \\
--- \\
--- \\
\cdots \\
0.09 \\
0.17 \\
0.07 \\
0.07\end{array}$ \\
\hline $\begin{array}{l}\text { Note: All measur } \\
\text { Number }=\text { Numbe }\end{array}$ & $\begin{array}{l}\mathrm{cm} . \\
\mathrm{s} \mathrm{me}\end{array}$ & & & \\
\hline
\end{tabular}

\section{Discussion of Attributes:}

Variety B is distinguished by a depressed circle $(2.9 \mathrm{~cm}$ dia. average) in the center of the well, created by additional pressure during the throwing process. The width of the central underglaze ring is greater $(1.1 \mathrm{~cm})$ than that in the center of Variety A. All other characteristics of this variety are consistent with Variety A. 
Snail, Variety C (Figure 34)

Total Sherd Count: 9

Minimum Number of Vessels (MNV): 9

Glaze: opaque and nearly white (Table 5)

Footring: clean, sharp and well-trimmed; shallow depth (Figure 8)

Measurements for Snail, Variety C

\begin{tabular}{||l|c|c|c|c||}
\hline Attribute & Number & Range & Mean & SD \\
\hline Rim Diameter & $\cdots-.-$ & --- &.-- & --- \\
Wall Thickness & 1 & 0.3 & 0.3 & 0 \\
Inside Depth & 1 & 2.9 & 2.9 & 0 \\
Outside Height & 1 & 4.0 & 4.0 & 0 \\
Footring Diameter & & & & \\
$\quad$ Outside & 6 & $9.0-9.4$ & 9.2 & 0.12 \\
Inside & 6 & $7.9-8.1$ & 8.0 & 0.06 \\
Footring Depth & 8 & $0.4-0.5$ & 0.5 & 0.04 \\
Footring Width & 8 & $0.5-0.6$ & 0.5 & 0.05 \\
& & & & \\
\hline
\end{tabular}

Note: All measurements in $\mathrm{cm}$.

Number $=$ Number of vessels measured

\section{Discussion of Attributes:}

The clay body of Variety $\mathrm{C}$ is whiter and more dense than that of

Variety A or Variety B. The diameter of the central underglaze ring averages

$2.4 \mathrm{~cm}$, and the average width of that ring is $1.0 \mathrm{~cm}$, making it almost twice as wide as the central ring in Variety A and comparable to Variety B. Although the fragments of this variety show little of the characteristic snail design element, there is enough to identify this as a separate variety. 
Snail, Variety D (Figure 35)

Total Sherd Count: 15

Minimum Number of Vessels (MNV): 10

Glaze: semi-opaque, blue-gray (Table 5)

Footring: wide at base, angled at corners and somewhat pointed at apex (Figure 8)

\begin{tabular}{||l|c|r|r|r||}
\hline \multicolumn{5}{|c|}{ Measurements for Snail, Variety D } \\
\hline Attribute & Number & Range & Mean & SD \\
\hline Rim Diameter & 2 & $17.8-18.0$ & 17.9 & 0.1 \\
Wall Thickness & 4 & 0.4 & 0.4 & 0 \\
Inside Depth & 3 & 2.9 & 2.9 & 0 \\
Outside Height & 3 & $4.0-4.1$ & 4.05 & 0.05 \\
Footring Diameter & & & & 0.51 \\
Outside & 8 & $7.6-9.4$ & 8.78 & 0.51 \\
Inside & 9 & $7.0-8.9$ & 7.73 & 0.07 \\
Footring Depth & 10 & $0.5-0.7$ & 0.54 & 0.11 \\
Footring Width & 10 & $0.5-0.8$ & 0.64 & \\
\hline \\
Note: All measurements in cm. \\
Number = Number of vessels measured
\end{tabular}

\section{Discussion of Attributes:}

The diameter of the central ring, averaging $3.0 \mathrm{~cm}$, is considerably larger on Variety D than on Varieties A, B or C and the width of that ring, at $0.4 \mathrm{~cm}$, is narrower.

The arrangement of design elements on this variety are similar to those on Varieties A, B and C, but the elements themselves are greatly devolved with a cursive quality to them. The presence of multiple iron inclusions in the clay body is also a distinctive attribute of this variety. None of the other varieties has iron spots to this extent, which suggests that the clay for this 
variety may have originated from a different source. In addition, the clay is coarse and poorly integrated.

One anomaly of this variety is noteworthy. A single sherd has a glazed well, whereas all other sherds of this and the other varieties have a bisque stacking ring. Was this vessel at the top of the stack in the kiln, and is this an example of glaze drift onto the bisque area during firing? 
SNAIL, Variety E (Figure 36)

Total Sherd Count: 71

Minimum Number of Vessels (MNV): 40

Glaze: semi-opaque, blue-gray (Table 5)

Footring: angled, somewhat triangular and flattened at apex (Figure 8)

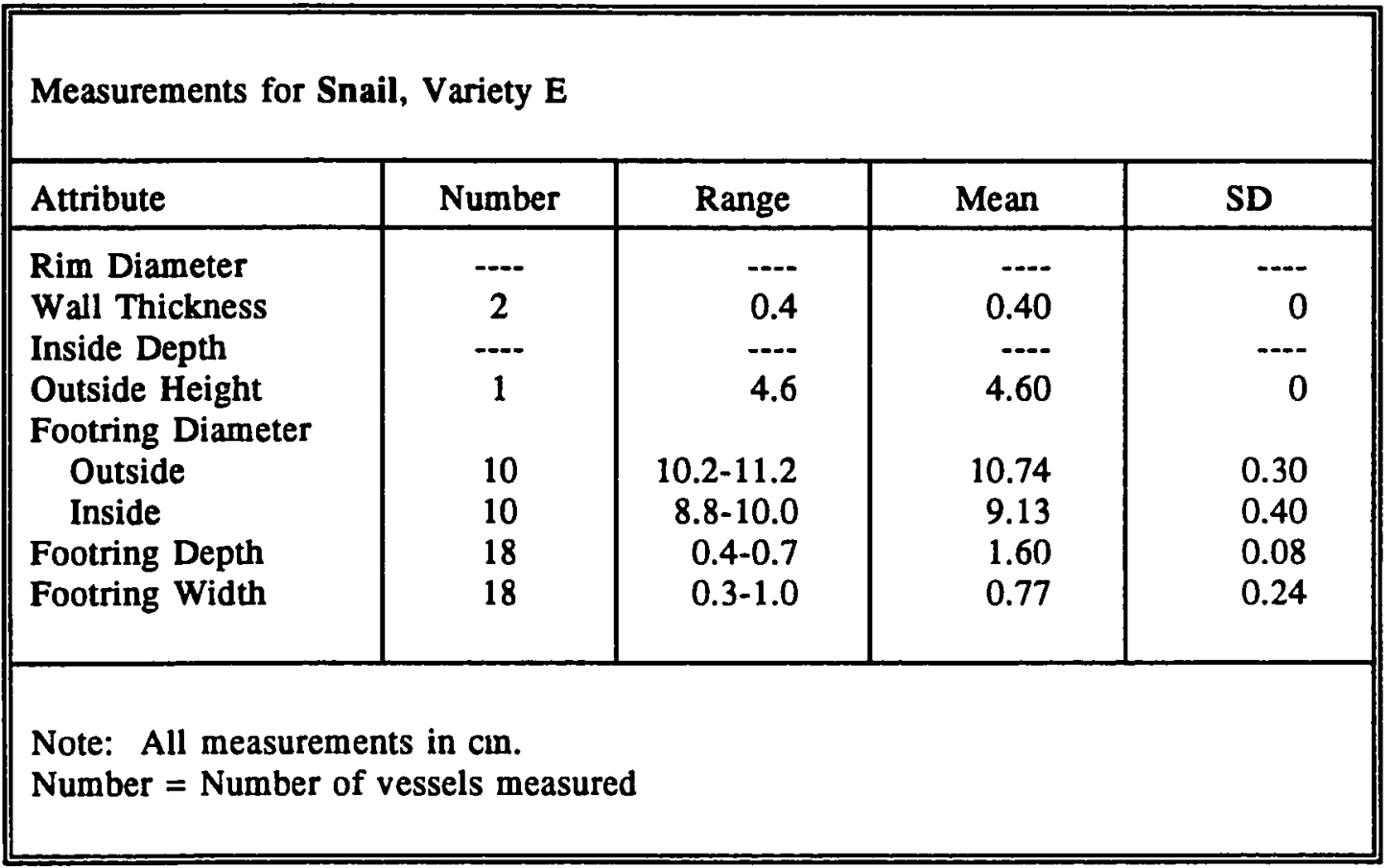

\section{Discussion of Attributes:}

Variety $\mathrm{E}$ is a larger, heavier vessel than any of the other varieties. Although the glaze color is the same as Variety D, the central ring of underglaze is larger in diameter $(4.3 \mathrm{~cm}$ average) than that of the other varieties.

The most distinctive feature of Variety $\mathrm{E}$, aside from its size, is the arrangement of the underglaze bands on both interior and reverse surfaces. Unlike the others, this variety has two bands of underglaze encircling the juncture of the cavetto and the well. On the reverse, a line has been deeply 
incised at the juncture of the footring and shoulder, then overlaid with a band of underglaze. Two additional, closely-spaced bands lie approximately 1.0 $\mathrm{cm}$ above that band. The deep incising to delineate the footring, plus the trimming technique of the footring, are unique to this variety. Although this variety has some of the elements of the Variety A design motif, it is not possible to accurately identify the design element on the cavetto. 
Type: Six Treasures (Figure 37)

Total Sherd Count: 1

Minimum Number of Vessels (MNV): 1

Clay: porcelain

Glaze color: clear; gray; hints of rose color on the reverse

Underglaze color: dark gray-green to black

Surface texture: smooth

Form: shallow saucer-plate

Rim: rounded edge (Figure 8)

Footring: narrow; rounded (Figure 8)

Measurements for Six Treasures Type

\begin{tabular}{|l|c|c|}
\hline Attribute & Number & Measurements \\
\hline Rim Diameter & 1 & 16.5 \\
Wall Thickness & 1 & 0.4 \\
Inside Depth & 1 & 1.4 \\
Outside Height & 1 & 2.7 \\
Footring Diameter & 1 & 10.0 \\
$\quad$ Outside & 1 & 9.1 \\
$\quad$ Inside & 1 & 0.4 \\
Footring Depth & 1 & 0.4 \\
Footring Width & & \\
\hline
\end{tabular}

Note: All measurements in $\mathrm{cm}$.

Number $=$ Number of vessels measured.

\section{Discussion of Attributes:}

Only one specimen of this type was recovered from the Frolic.

Although it is not strictly blue-and-white in color, the type merits consideration as one of the seven predominant Frolic types because it is a whole vessel.

Viewing the plate, clockwise from the top as illustrated in Figure 37, design elements on the cavetto and in the well of the vessel represent a harp 
or rhinoceros horn (Foo, pers. comm.), an unknown item, a peach, a gourd, another unknown, and a sword. Two butterflies are portrayed in the well. According to Maust (1973):

[The Chinese long ago] adopted an inclusive name for their groups of decorative symbolic units, $\mathrm{Po} K u$, which may be translated Hundred Antiques, although these decorative units are by no means limited in number to one hundred .... .

These symbols are depicted in many forms but they are always accompanied by fillets, which represent the bits of red cloth the Oriental ties to prized objects. In Chinese art, the fillet is an aura emanating from the symbol much as the nimbus above a saint or a god. $(16,41)$

The decorative symbols on this plate seem to be loosely connected by just such fillets as those described above.

Groups of symbols may include as few as five units within a group, determined by whatever number the artist requires, and may be either Buddhist or Taoist, or even unconnected to any particular religion. In this instance, the "sword, gourd and rhinoceros horn are Buddhist Symbols which have been simplified during the late Qing period" (Foo, pers. comm.).

The hint of rose color on the reverse of the vessel could be due to:

1. a thin or uneven application of the glaze allowing clay impurities to bleed through;

2. uneven mixing of glaze constituents; or,

3. discoloration due to location of the vessel in the kiln during firing. Although one informant (Kao, pers. comm.) indicated that the character on the reverse was Mandarin (Figure 38), not all informants agreed with that opinion. Alfonz Lengyel (pers. comm.) wrote that the character is not Chinese and that the plate was possibly an early nineteenth century vessel 
used in a ship's kitchen. Fr. Jesus Antolinez of the University of Santo Tomas, Manila, suggests that the design indicates Annamese ware (pers. comm.). No consensus has been reached about the origin of this saucer-plate, the meaning of the character on the reverse, or the design elements on the cavetto. Since no other vessel of this type was recovered from the Frolic, it may be the only surviving example of the ship's kitchenware or perhaps a unique and single example of a ship's officer's private collection, acquired elsewhere than in Canton. 
Type: Ginger Jar (Figure 39)

Total Sherd Count: 5

Minimum Number of Vessels (MNV): 1

Clay: porcelain

Glaze color: clear

Underglaze color: dark blue

Surface texture: smooth

Form: Ginger jar

\begin{tabular}{|c|c|c|}
\hline \multicolumn{3}{|c|}{ Measurements for Ginger Jar Type } \\
\hline Attribute & Number & Measurements \\
\hline $\begin{array}{l}\text { Rim Diameter } \\
\text { Wall Thickness } \\
\text { Inside Depth } \\
\text { Outside Height } \\
\text { Footring Diameter } \\
\text { Outside } \\
\text { Inside } \\
\text { Footring Depth } \\
\text { Footring Width }\end{array}$ & $\begin{array}{l}1 \\
1 \\
1 \\
1 \\
1 \\
1 \\
1 \\
1 \\
1\end{array}$ & \begin{tabular}{c}
$7.5^{*}$ \\
0.4 \\
15.6 \\
16.6 \\
\\
$15.0^{*}$ \\
\hdashline 0.5 \\
0.8
\end{tabular} \\
\hline \multicolumn{3}{|c|}{$\begin{array}{l}\text { Note: All measurements in } \mathrm{cm} \text {. } \\
\text { Number }=\text { Number of vessels measured } \\
{ }^{*} \text { Estimated measurement }\end{array}$} \\
\hline
\end{tabular}

\section{Discussion of Attributes:}

Two large blue-and-white Ginger Jar sherds were joined to render an estimation of the overall shape and size of the original vessel. This single example of a Ginger Jar is decorated with the blue-and-white Canton pattern, a nineteenth century design motif that usually includes houses, mountains, boats and a bridge. 
The Canton design, so-called because undecorated ware was shipped from kilns to Canton for painting, commonly had one of two principle border designs: a "straight-line" border, similar to that seen on this Ginger Jar, or a "rain and cloud" border, as seen on the miscellaneous blue-and-white sherd in Figure 6a (Schiffer 1975:17,20).

Ginger $\operatorname{Jar}(\mathrm{s})$, the term usually applied to ceramic vessels shaped in the form of this specimen, were generally used to hold ginger and other spices exported from China. 


\section{Chapter IV \\ REVIEW OF SITE COMPARISONS}

\section{Pacific Rim Historical Sites}

Campbell Macknight of the Australian National University in Canberra observes that "in general, not much is known about everyday Qing wares ... though everyone knows that there's a lot of the stuff about" (pers. comm.). This statement seems to sum up the view of most informants responding to inquiries for this research. Although Qing ware is distributed throughout the South Pacific, its presence is not necessarily a marker of overseas Chinese settlement sites. For example, Chinese bowl sherds have been found in eighteenth and nineteenth century campsites of Indonesians who were hunting bêche-de-mer (sea cucumber) in Australia (Macknight; Leibrick; Crawford; pers. comm.).

The following review, by region, is based on information generously shared by archaeologists and ceramic specialists in Australia, New Zealand, Southeast Asia, and the Philippines.

\section{Australia}

Archaeology in Australia incorporates sites in most of the coastal regions of the country (Figure 40). In the Western Australia community of Cossack, near Roebourne (approximately 1600 kilometers north of Perth), the disturbed site of an Asian settlement yielded rice bowl sherds with "pottery marks in old Chinese script" (McIlroy 1988:139). In addition, sherds of "Asian" transferware and brown-glazed stoneware were found. Although 
ceramics were frequently identified as "Asian," "Chinese" or "Japanese," none apparently were comparable to Frolic ware. Photographs included in the Cossack site report (Mcllroy 1988:158) showed one sherd of Double Happiness, a pattern seen often in California sites but not found in the Frolic collection.

In 1839, a storm destroyed the barque "Elizabeth" at the mouth of the Swan River near Fremantle, Western Australia. Fragments of Chinese ceramics recovered at that site included a sherd of Peach \& Fungus with a catherine wheel, or swirl, design in the center of the well (Henderson 1973:39).

"Chinese bowls" were in use in the 1840s at a Mission Bay site in Western Australia (Crawford, pers. comm.), but the specifics of bowl type were not available.

The Material Culture Unit of James Cook University in North Queensland holds ceramics recovered from a site in Atherton, North Queensland. Comparison of these ceramics with the Frolic ceramics revealed similarities, however, the design motifs were identified by different names, assigned by Wei Ming Jia, a visiting $\mathrm{Ph}$. $\mathrm{D}$. candidate in archaeology from China. He refers to Rocks \& Orchid, Bamboo, and Peach \& Fungus all as "flowers and grass," with Peach \& Fungus also being called "acanthus." $\mathbf{M}$. Wei is in agreement that the principal design element in the Frolic Snail type is, in fact, a snail and not a shrimp. He states there is nothing similar to the Frolic Snail type in the Material Culture Unit collection nor is there anything similar to the Frolic Fu type in that collection (M. Wei, pers. comm.). 
Campbell Macknight reports that he has purchased "antique" Peach \& Fungus in Jalan Surabaya in Jakarta, and has a Peach \& Fungus sherd from the Wobalinna Island site in Port Bradshaw south of Cape Arnhem in the Gulf of Carpentaria. As for the Rocks \& Orchid, Fu, and Snail types, Macknight is of the opinion that they are typical of "very similar material found all round the Pacific especially ... in areas of Chinese settlement." He further states:

My own work on the campsites of Indonesians cooking trepang (beche-de-mer, sea cucumber) on the coast of Arnhem Land between about 1720 and 1906 is another case where Chinese were not directly involved, but amidst a mass of Indonesian earthenware there are occasional sherds of Chinese bowls, spoons and the like.

Chinese ceramics occur at two major archaeological localities in the Northern Territory; both are post-1870 gold-mining sites (Leibrick, pers. comm.). A gold find at Pine Creek in 1870, during construction for telegraph lines, brought an influx of indentured Chinese laborers to the mines by 1874 (National Trust, n.d.). The Pine Creek site was investigated in 1985 and although a high level of surface scatter was evident, very few intact items were recovered. The ceramics catalog included in the site report lists 10 entries of porcelain sherds with cobalt underglaze (McCarthy 1986:22); however, "none of the patterns appear to correlate with those" of the Frolic (McCarthy, pers. comm.). Identification efforts concentrated on function rather than pattern analysis (Bell, pers. comm.).

Photographs of a surface scatter of artifacts in the vicinity of Pine Creek show at least one, and possibly two sherds which could be the Snail type. These sherds are quite small, perhaps no more than 5 to $6 \mathrm{~cm}$ in length and difficult to accurately assess by looking at a photograph. If they are 
Snail, they would be the first instance of that type to be reported in Australia. Otherwise, the Pine Creek site collection yielded few items which allowed type identification. Most of the fragments in the collection were apparently without pattern, and those that did have patterns were unlike the Frolic ware.

A second site, Ah Toy's Garden, a Chinese market garden on the Palmer River goldfield in North Queensland, was surveyed and excavated in 1982. Ceramic artifacts at the site included green-glazed ware, some small, unidentified ceramic sherds, and rice bowls (Jack, Holmes and Kerr 1984:5456). The total count of rice bowls was not listed, nor was there a type identification, however, drawings included in the report show that at least two rice bowl shapes were present. Since the Chinese did not arrive in the Palmer River area until the early 1870 s, these artifacts would post-date the Frolic ware by twenty years or more.

There were three "Chinese goldrush" shipwrecks in Guichen Bay, South Australia, but to date they have not been located (Bell, pers. comm.).

Over and over, informants from Australia generously offered information about goldfield sites which were worked by Chinese laborers, but information was often sketchy due to the absence of any extensive archaeological work at these sites.

\section{New Zealand}

New Zealand Regional Archaeologist, Neville Ritchie, is reputedly the most knowledgeable investigator of Chinese history in the South Pacific (Leibrick, pers. comm.). He states that to his knowledge no examples of Rocks \& Orchid, Peach \& Fungus, Fu, or Snail have been found in New Zealand sites although he does indicate that designs similar to those seen on 
Fu plates have been seen in Indonesia. The first Chinese arrived in New Zealand in 1866 , and possibly by then the Chinese export market had changed, or possibly Frolic type ceramics were not exported to New Zealand. The familiar Bamboo pattern is found in New Zealand, but it is not seen as often as Celadon or Four Seasons, two types frequently seen in California and other western United States sites (see Selected Western United States Historical Sites).

\section{The Republic of the Philippines}

Fr. Jesus Antolinez responds that the Rocks \& Orchid, Peach \& Fungus, Fu, and Snail vessels pictured give the impression that they are older than the nineteenth century. He further states that the design of Six Treasures indicates Annamese ware. The 1850 date of the Frolic ceramics is indisputable, however, it is probable that this particular plate was not part of the cargo, as mentioned earlier. In that case, it could very well be Annamese. The Six Treasures plate is the only vessel of its type in the collection and to date its identity is undetermined.

Gabriel Casal, Director of The National Museum in Manila, reports that the museum has plates that are commonly called "Singapore ware or English ware" which are "exactly like" Rocks \& Orchid, Fu, and Snail "but they differ only in design." This baffling contradiction can be explained by understanding that the National Museum vessels may be similar to Frolic vessels, but have vessel forms or design elements which vary. For example, a number of design elements similar to Rocks \& Orchid are traceable to late Ming and early Qing motifs, and although those vessels are similar to the Frolic Rocks \& Orchid, they are not the same. Without seeing the National 
Museum ceramics (photographs from the museum collection were not available), it would be speculation to conclude whether they are the same types as the Frolic vessels.

Casal further points out that "Ch'ing [Qing] pieces in the Philippines come in different sizes, shapes and design" and they "differ from those recovered in the Western Hemisphere in details and design." Rocks \& Orchid is described in the Philippines as "blue and white with rocks and peonies and a tree of life at the center" whereas Rocks \& Orchid from the Frolic has an orchid motif emanating from a central rock design. Casals states that "no porcelain of this age was found in excavations" with the exception of a few surface finds of sherds from the southern part of the island of Luzon (Figure 41). There were "two retrievals" from shipwrecks in the central part of the Philippines, but written reports covering these shipwrecks, citing these names, dates and locations, were not forthcoming.

Finally, Casal says that mid-nineteenth century Chinese export ceramics were used in Filipino homes as well as in Chinese homes.

\section{Southeast Asia, Malaysia and Indonesia}

In Malaysia, the Rocks \& Orchid, Fu, and Snail designs are apparently commonly found in archaeological sites in Sabah (Figure 41). These types also have been recovered from excavations in Melaka, Johore, Kelantan, Penang, Perak and Pahang in Malaya (Figure 42), but reports from these sites have not yet been published (Yatim, pers. comm.).

Jimmy Foo of the Sabah Museum writes that the Peach \& Fungus, Fu, and Snail appear to be typical of types produced in Guangdong Province, China and "are all dated to the second half of the nineteenth century." $\mathrm{He}$ 
further states that "dishes with an inner biscuited band and decorations in underglaze dark blue are commonly found in archaeological sites in Sabah and Southeast Asian Countries." Both Fu and Snail have an inner biscuited (bisque) band. About Peach \& Fungus, Foo writes that bowls with a devolved Peach \& Fungus design were still in production in 1990 in Guangdong Province.

Furthermore, Tuton Kaboy writes from the Sarawak Museum:

We have found plenty of ceramics of the same type [as Rocks \& Orchid, Bamboo, Peach \& Fungus, Fu, Snail and Six Treasures] .... still being used by the people in the interior . . . and dated 19th-20th century. (Kaboy, pers. comm.)

Willetts and Lim (1981:v) state that blue-and-white "Kitchen Ch'ing" can be found "in practically all Malaysian households, indeed throughout the whole of Southeast Asia."

A monograph published by the Southeast Asian Ceramic Society (Lam, Carswell, Russell et al 1985:134) illustrates sherds of "everyday ceramics" imported from China and found at Nipah on Tioman Island (Figure 42). The types illustrated are a Peach \& Fungus saucer-plate with a catherine wheel in the center of the well, a second fragment of a Peach \& Fungus bowl, and a Rocks \& Orchid saucer-plate.

Chinese ceramics have been found at Macassan fishing sites in south Sulawesi, Indonesia (Figure 41), but to date "there has been very little research done on these sites, and virtually nothing published" (Leibrick, pers. comm.).

In Vietnam, ceramics have been found in sites near Ho Chi Minh City and at Hoi An, approximately 16 kilometers southeast of DaNang (Figure 41), and "people there are waiting for scholars to come and tell them the dates of 
what they've found" (Ngerntongdee, pers. comm.). This informant also states that Fu patterned dishes are common in Southeast Asia, particularly in Indonesia, and that they were made in Guangdong province and in Hong Kong. She notes that Peach \& Fungus is commonly seen, although with flatter walls than the Frolic Peach \& Fungus type and with everted rims. She refers to the "landscape dish" (Rocks \& Orchid) as a common find in Southeast Asia.

Chuimei Ho of the Field Museum of Natural History in Chicago writes that "low quality late blue-and-white wares. . sometimes turn up in Thail and Indonesian archaeological sites." She thinks that the Frolic Fu and Snail bowls were both from kilns in Hong Kong. Peach \& Fungus bowls, referred to as "Minnan pattern," were produced at Minnan district sites in Anxi, Yongchun and Dehua prefectures of Fujian province and at Jingdezhen (Ho 1987:120; Ho 1988:82,158; Ho, pers. comm.). Blue-and-white wares were also produced at Dapu and Yaoping in Guangdong province, and at the Dapu kiln in Hong Kong (Figure 2) (Ho, pers. comm.; Kwan and Martin 1985:80).

Further support for Ho's opinion comes from the 1985 publication, $A$ Ceramic Legacy of Asia's Maritime Trade, which states in regard to Peach \& Fungus that "bowls and plates with this design have been found at a number of kilns at Dehua. It has been estimated that some 50 kilns used this design on their wares" (Lam, Carswell, Russell et al 1985:80). Minnan wares, according to Ho, "should be considered as one large regional entity," since they share similar potting, decorating, and firing techniques (Ho 1987:120). Furthermore, access to overseas markets was better from the coastal sites of Fujian thus the "coarse wares of utilitarian shapes familiar to Asians, and 
perhaps to overseas Chinese in particular" were easily exported (Ho 1987:132).

Photographs sent to the Victoria and Albert Museum in London were returned with the comment: "they are absolutely typical of the types of cheap export wares from South China kilns that were in wide circulation in the Southeast Asian-Pacific trade, certainly from the late 18th century and continuing into this century" (Guy, pers. comm.). Guy further comments that these are typical of wares which are prevalent in the Philippines, but he does not mention specific patterns and motifs which might be the same as those from the Frolic.

Kitchen Ch'ing (without a specific reference to type) has been seen at St. Helena off the west coast of Africa and at Nipah, Juara and Tekek, on Tioman Island off the east coast of Malaya (Figure 42) (Kwan and Martin 1985:80).

A recent look at a private collection belonging to Shirley Ganse in Seattle, Washington revealed sherds of Rocks \& Orchid and Peach \& Fungus which she picked up from a beach on P'enghu (Penghu) Island offshore from Taiwan (Ganse, pers. comm.). She had, as well, a Peach \& Fungus saucer-plate with a two-tiered pattern in the cavetto, larger by two centimeters in diameter than any of the large rice bowls in the Frolic collection. A smaller rice bowl of Peach \& Fungus, comparable in size to Frolic vessels with the Bamboo pattern, was also in the collection. On a recent trip to China, Ganse saw a drying rack "full of Peach \& Fungus" at Jingdezhen, confirming that this particular type is still being produced at that kiln site. 
Examination of the privately owned Scheans collection in Portland, Oregon revealed most of the Frolic collection types: Peach \& Fungus, Rocks \& Orchid, and Fu. Also included was a version of Snail, though it was dissimilar in enough elements to say that it is not the same as any of the Frolic Snail varieties. All of these antique pieces were obtained from Thailand, the Philippines and Malaysia during the mid-twentieth century. As recently as the 1960s the Fu type was being avidly sought by Philippine collectors (Scheans, pers. comm.).

\section{India}

The Anthropological Survey of India indicated that no ceramics of these types were in their collection (Bhattacharya, pers. comm.).

\section{Chile and Peru}

Inquiries were sent to the following museums in Chile: The Museo Arqueologico in La Serena, the Museo Historico Nacional in Santiago, and the Museo Antropologico in Iquique. None responded. Likewise, no response was received to an inquiry to the Museo Arqueologico Rafael Larco Herrera in Lima, Peru.

\section{Discussion}

A review of responses and collections from the above countries shows that there are some similarities between Frolic vessels and ceramics recovered from the South Pacific and Southeast Asia, with the most widespread frequency of occurrence in Australia and Malaysia (Table 12). It is apparent from the comments of informants, however, that site excavation has been limited and published reports are scarce. There is awareness that a substantial body of work remains to be done in the South Pacific, and a 
potential exists for the exploration of sites and recovery of material to

provide more data on nineteenth century Chinese export ceramics.

Selected Western United States Historical Sites

In 1848, gold was discovered in California and by 1849 , the Gold Rush had begun.

Shipmasters capitalized on the great excitement [of the discovery of gold] by distributing maps, placards, and pamphlets concerning the "Golden Hills" (Sandmeyer 1939:14). The political and economic depression of China coupled with the lure of Prosperity in America sent many Chinese flocking to the United States with high hopes. (Wlodarski 1976:442)

Although Chinese were recorded in Baltimore as early as 1785 (Chinn 1973:7), reports of the first Chinese on the West Coast are confusing. Chinese were reportedly seen as early as 1815 in Monterey, and in 1838 the brig Bolivar was said to have anchored at Yerba Buena (San Francisco) with a Chinese cabin boy on board. In February 1848, the ship Eagle arrived in San Francisco carrying two Chinese men and two Chinese women, and the San Francisco Star, in an editorial dated April 1, 1848, reported "two or three Celestials" in the city. A July 21, 1878 issue of the San Francisco Chronicle reported that a merchant named Chum Ming had arrived in San Francisco from Canton in 1847 (Chinn 1973:8-9). By February 1849 there were 54 Chinese in San Francisco, and eleven months later, there were 787 men and two women. By 1852 the Chinese population in California was estimated at 25,000 (Praetzellis and Praetzellis 1982:13).

At the time of the Frolic shipwreck in July 1850, Chinese in California were not sufficiently numerous to support a market for export ceramics. The 
ceramics trade was instead aimed at the Euro-American population and it was for this market that the Frolic shipment was intended. Mueller (1987) states:

Asian porcelain and porcelaneous stoneware [vessels], known collectively by Chinese artisans as $t z^{\prime} u$ (Medley 1976:13), have been recovered from every overseas Chinese archaeological site excavated in California. They also have appeared as components in many historical excavations in the western United States as well as Southeast Asia. (259)

Fragments of ceramic vessels similar to some of the Frolic ware have been recovered from almost every excavated mining camp, railroad campsite, and Chinese community in California. Chinese workers who arrived after 1850 often brought along their own personal food vessels. They commonly would have in their possession only one or perhaps two dishes which served double-duty, such as a combination rice-soup bowl, or in some instances, a rice-soup-tea bowl. The owners of these vessels sometimes chiseled or pecked their Chinese names in the wells of the bowls. Although personalized bowls of this sort have been found in sites throughout California, none were found in the Frolic shipment.

Because the Frolic shipwreck occurred on the northern California coast and the cargo was destined for San Francisco and a California market, this research has focused primarily on California archaeological sites. Regional studies and comparative collections in Oregon, Idaho, Arizona and Nevada have been looked at, but not as extensively as those in California. Figure 43 illustrates the sites discussed below.

\section{California}

The Ventura Chinatown was an established community by the 1870 s, however, the exact date of its establishment is unknown (Wlodarski 
1976:443). Excavation between 1974 and 1976 revealed two trash pits (Features 24 and 25) associated with the Chinese community. The ceramic wares from these two features are predominantly Chinese and include both domestic tableware pieces and food containers (Benté 1976:461).

Feature 24 was a well fill, located behind a Chinese laundry. One hundred fifty-four countable vessels of Chinese ceramics were recovered. Deposits in Feature 25, a trash pit, also located behind a laundry, included 65 vessels. "Most of the stoneware food containers were intact or almost completely reconstructible [sic], whereas almost all of the porcelain table wares present were broken and lacked major sections ...." (Chace 1976:512). Although there was some duplication of types and varieties found in both pits, sherds from the two features were incompatible for joining. The well fill contained transferware and "genre scenes" in patterns not found in the trash pit (Chace 1976:513). Types represented in both features were Bamboo, Celadon, and Four Seasons, plus brown-glazed stoneware food jars and a Ginger Jar. Double Happiness, a type commonly recovered at most other sites of this period, was not found here. The only type in the Ventura collection comparable to the Frolic ceramics is Bamboo.

Excavation of the late nineteenth century Chinese community of Wong Ho Leun, at Riverside, revealed a large assemblage of a "minimum of 2,767 vessels" of Chinese, Japanese and Southeast Asian manufacture. This community was "an essentially intact urban settlement .... including residents of Chinatown, rural Chinese workers, the Euroamerican economic sector, Euroamerican visitors, and the Japanese population" (Mueller 1987:259). Ceramic types from this site include "Pale Jade Green" (Celadon), 
"Shuang Hsi" (Double Happiness), "Three Friends" (Bamboo), "Four Seasons," and a miscellaneous assortment of additional types including polychrome ware, Rose Canton, some Japanese ware and "Southeast Asian" types.

Of the types which compare to the Frolic, Bamboo (identified by Mueller as "Three Friends") is described as an "Eating Bowl" and represents $17.2 \%$ (475 vessels) of the minimum number of vessels in the collection (Mueller 1987:264). A second type, termed "Southeast Asian" (Mueller 1987:289), is similar in potting and glaze application to Snail, however, unlike the Snail this vessel has a swirling, free-form design motif on the reverse of the cavetto (Figure 44a). It appears to be heavily potted, coarse, porcelaneous stoneware with a hastily and poorly applied glaze. A wide band of glaze covers the reverse except for the footring and base which are unglazed. One basal sherd of Rocks \& Orchid is illustrated but not identified (Mueller 1987:281).

The Tucson Urban Renewal Project site (Lister and Lister 1989:49) contains an example of a similar vessel which has a free-form design on the reverse (Figure 44b). The footring of this vessel is broad and shallow, with a slight sloping toward the interior of the base, whereas the Riverside vessel has a deep, narrow footring. The vessels from these two sites are close enough in appearance to suggest that they could be from the same kiln source. Since the cavetto and well designs were not available for either vessel, it would be speculation whether these are Snail look-alikes, or simply a separate type altogether. 
The Estrada Adobe in Monterey (CA-MNT-1243H) was part of a group of archaeological features found next to the existing Soberanes Adobe during excavation in 1983 (Laffey, Benté, Cartier et al 1985:1). The structure possibly dates from 1841-42 (Laffey and Benté 1985:88), during a period which saw a predominantly Hispanic and Mexican population in the Monterey community. Upon California's 1846 separation from Mexico, a significant occupation by the American military occurred (Laffey and Kimbro 1985:12,21). Throughout this period, Monterey was also an important port and trading center, welcoming "sailing ships with goods from the Orient, Mexico and Europe" (Benté 1985:46).

Of the 460 ceramic sherds recovered from the Estrada Adobe, a total of forty were determined to be Chinese (Benté 1985:49). The ceramic assemblage included "miscellaneous blue and white, brown-glazed stoneware, Canton, Nanking and Sino-Islamic" wares, and ten fragments of Fu plates. In addition, the published report shows one fragment which is unquestionably Peach \& Fungus. Examination of a portion of the collection revealed one basal sherd, two rim sherds and one body sherd of Peach \& Fungus. Also observed in the collection was a brown-glazed sherd similar in color and texture to the brownware in the Frolic collection.

A second Monterey adobe associated with Chinese ceramics, the Cooper-Molera Adobe, is an existing complex of structures owned by the National Trust for Historic Preservation and operated by the California Department of Parks and Recreation (Felton and Schulz 1983:1). The adobe house was built during the 1820 s or 1830 s by J. B. R. Cooper, and in 1833 the property, including a portion of the house, was subdivided. A portion of 
it then passed through a number of ownerships until 1845, when it was sold to a merchant, Manuel Diaz (Felton and Schulz 1983:3). Upon Diaz' death, the property again changed ownership but continued to be occupied by Diaz' widow until the late 1890s. In 1900 , the property was sold once again and eventually ownership passed to a member of the Molera family (who also happened to be a descendent of Cooper's). In 1968, the property was willed to the National Trust, and in 1973 the first of several excavations occurred at the site.

A ceramic assemblage of 118 complete and partial vessels was collected from "a mid-nineteenth century privy deposit associated with the Diaz family" (Felton and Schulz 1983:1). The assemblage included a partial bowl and a small wine cup with the Peach \& Fungus design, and sherds of ginger jars similar to those in the Frolic collection. In addition, British transferware, brown earthenware, a "low-fire nonwhite ceramic," and other "common pottery" types were recovered (Felton and Schulz 1983:27-28).

In San Jose, the San Antonio Plaza Redevelopment Area includes the section in downtown San Jose bordered by South First, San Fernando, Market, and San Antonio Streets. This is the approximate location of the mid-to-late nineteenth century San Jose Chinatown (c. 1852-1887), an area that was repeatedly destroyed by fire, as were many other Chinese communities of that period. The archaeological assemblage recovered during the 1985 excavation is currently housed at the San Jose Historical Museum. A report describing the collection has not been prepared. Examination of the ceramics in the assemblage revealed examples of two Frolic ware types: Rocks \& Orchid and Bamboo. One Rocks \& Orchid saucer-plate is the same size as those in 
the Frolic collection, although not as well crafted or painted. Another is larger, approximately $22.5 \mathrm{~cm}$ diameter. Although most of the ceramics recovered from this site are polychrome, examples of Four Seasons, Double Happiness, and Nanking ware are also present. An example of Peach \& Fungus is in the collection (Flynn and Roop, pers. comm.), but it was not seen.

In 1985, excavation at Sacramento and Battery Streets in San Francisco exposed the remains of the Hoff Store, once a San Francisco waterfront retail emporium that was destroyed by fire in May of 1851. A substantial collection of Chinese export porcelain was included in the material culture excavated from the site. Brown-glazed earthenware, toiletry sets, wash basins, water bottles, brush boxes, soap dishes, and chamber pots were among the ceramic artifacts recovered. These were described in the published report (Terrey and Pastron 1990:75) as "white, dense, slightly grainy hard-paste porcelain" with varying underglaze blue patterns of chrysanthemum and sweet pea. None of the specimens in the report matches ceramics in the Frolic collection, however, the design elements on an illustrated chamber pot appear to be the "Canton" pattern and are similar to those on the Frolic Ginger Jar (Terrey and Pastron 1990:79).

A second San Francisco site, China Camp, was known as an important shrimp fishing and processing location on San Francisco Bay. Although the camp was at its peak in the 1880 s and 1890 s, the recovered assemblage dates between 1870 and 1911. Twenty-seven Bamboo bowls and 262 Bamboo sherds were recovered (ii is noteworthy that none of these bowls contained marks within the footring). Peach \& Fungus was also present at this site. 
The inventory lists five shallow bowls and one bowl sherd, and two saucers and one saucer sherd. A serving bowl of the Fu type was listed, but it is a different variety from the Frolic Fu. Non-Frolic types recovered included Celadon and Double Happiness (Schulz, pers. comm.).

The Chinese community in Sacramento, known as Little China, was destroyed by fire in July 1854 and again in July just one year later (Praetzellis and Praetzellis 1982:16). Excavation of the site in 1981 yielded examples of Celadon, Double Happiness, Four Seasons, brown-glazed stoneware, "Canton Ware," and miscellaneous sherds of "blue handpainted" ware (Praetzellis and Praetzellis 1982:129-133). Examination of the ceramic artifacts from the site showed that this "blue handpainted" ware was unlike any of the types seen in the Frolic collection.

Thirty miles south of Sacramento, in the Delta community of Walnut Grove, the "historically documented Chinatown" contained 659 items of table ceramics (out of a total ceramic assembalge of 1106). The assemblage represented the period from the late nineteenth century to the early twentieth century (c.1880 to 1915)(Costello and Maniery 1987:16). Bamboo, Celadon, and Four Seasons were among the ceramics recovered, but only the Bamboo type is in the Frolic collection.

The Yolo County town of Woodland was created in 1855 with the establishment of a blacksmith shop and a general store (Felton, Lortie and Schulz 1984:5). By the 1860 s it was a settled community with a link to the transcontinental railroad. A "handful of Chinese" cooks and laborers were in Yolo county in 1860 , and by 1870 the Chinese laundry on Second Street was 
one of six Chinese laundries in Woodland. In 1880, there were "over a hundred Chinese living in" Woodland (Felton, Lortie and Schulz 1984:9,11). As a result of excavation in 1980, an assemblage of 240 Chinese ceramic sherds were recovered, including "nine sherds representing at least four rice bowls" of the familar Bamboo type. Also recovered were examples of Double Happiness, Four Flowers (Four Seasons) and Winter Green (Celadon), plus nine unidentified sherds (Felton, Lortie and Schulz 1984:40).

A general store named Kwong Tai Wo Company, believed to have been situated in Marysville (though this location is uncertain), operated during the last quarter of the nineteenth century. Business records preserved in the Bancroft Library at the University of California, Berkeley, contain shipping bills, inventories, sales bills and purchase orders which provide a record of the goods bought and sold by this company (Sando and Felton 1987:2-3). Translated store inventories of ceramic tableware list tea and wine cups, tea and wine pots, plates, and spoons in designs familiar to most California archaeological sites.

The particular value of these documents is that the sales and inventory records are written in Chinese, using ceramic type names that the Chinese themselves used, thus providing more authentic names for the various chinaware patterns and motifs of that period. A total of 5,253 vessels is included in the tableware inventories, with descriptions of types including "Winter Green," a name which is not usually associated with export ware of that period and which is thought to refer to the better-known Celadon (Sando and Felton 1987:7). Additional familiar types listed are Bamboo, Double Happiness, Four Seasons, and "Prosperity," more commonly known as Fu 
(Sando and Felton 1987:18). Of the types which compare to Frolic ware, 1,061 bowls or $20 \%$ of the total were of the Bamboo pattern (Sando and Felton 1987:14) and 132 were Fu vessels. Of these, ten had three $f u$ characters, 107 had two $f u$ characters, and the remaining fifteen were "large $f u$ character bowls" (Sando and Felton 1987:18).

As early as 1851 Chinese were living in the mining communities associated with the Igo and Piety Hill (CA-Sha-1512) placer mines in Shasta County southwest of Redding. The 1852 census indicates between 2,000 and 3,000 Chinese were in Shasta County, "although the number around Igo was probably small" (Ritter 1986:7). By the 1860 s the Chinese population in the Piety Hill vicinity was approximately 400 . Artifact remains associated with those communities include the usual ceramic assemblages seen elsewhere: Bamboo, Celadon (Winter Green), Four Seasons (also known as Four Flowers), brown-glazed stoneware, and miscellaneous sherds including EuroAmerican ceramics. "Sherds and bases of six and possibly seven Bamboo pattern" bowls were found (Ritter 1986:19). These Bamboo sherds were the only type comparable to Frolic ware.

In 1984 and 1985, thirteen sites in the Dutch Gulch Lake region of the Cottonwood Mining District were investigated. Between 1870 and 1880 these sites, situated mid-way between Red Bluff and Redding, saw a "six-fold" increase in Chinese population, from 50 to 328 (Tordoff 1987:iii). Ceramic assemblages excavated and surface collected from these sites reveal the presence of the same types seen at the Igo and Piety Hill sites, namely, Bamboo, Celadon, and Four Seasons, in addition to Double Happiness. Benté (1987:A-5) describes Bamboo rice bowls from this site as "Swatow style, 
utilizing a broad casual brush [resulting] in a readily recognizable motif with a relaxed quality." A total of 139 Bamboo bowl sherds are inventoried from nine of the Chinese sites covered in this study (Bente 1987:A-11).

By 1850 the Trinity County town of Weaverville was a trading and social center for miners, and by 1852 "the Chinese had become a visible ethnic group in that community" with houses for workers, "stores for imported Chinese goods," and an established Joss House (Dotta and Brott 1982:1-2). In April 1852, the Shasta Courier printed an article describing recently arrived Chinese men as follows:

An immense number of the uncouth visaged and picturesquely dressed sons of the Orient passed through this place during the week enroute for the Trinity mines. Each man had a long pole slung across his shoulder, pendant from either end of which was about 50 pounds weight in provisions, clothes or tools. (Hanover 1982:9)

Among the ceramic artifacts recovered during the excavation of Moon Lee One in Weaverville, the usual collection of types is included: "Three Circles and Dragonfly" (Bamboo), "Swirl" (Double Happiness), Celadon, and Four Seasons, along with blue handpainted ware, Canton ware and miscellaneous "utilitarian brownware" (Brott 1982a:87-112). Twenty-five (MNV) Bamboo vessels were excavated.

At Three Chop Village (MEN-790) in Mendocino County, 50 sherds of Chinese porcelaneous stoneware "believed to have been salvaged by the Mitom Pomo from the . . Frolic" (Layton 1990:183) were excavated in 1984. The two large Ginger Jar fragments in the Frolic collection exhibit the same design elements as those seen on many of the Three Chop Village sherds (Layton 1990:207). 


\section{Pacific Northwest}

Many Northwest sites associated with canneries, potteries, mines and railroads include Chinese cultural remains (Steele, pers. comm.). Chinese ceramic assemblages from sites researched for this study do not hold any material comparable to that recovered from the Frolic.

Near the Tillamook County, Oregon community of Netarts Bay (35-TI1), "127 fragments of Chinese porcelain" were recovered in an excavation which took place between 1956 and 1958 (Beals and Steele 1981:1). Initially these sherds were thought to date to the late Qianlong period (1736-1795) of the Qing dynasty, however, subsequent analysis attributes them to the period between the late Ming dynasty (c.1573) and the early Qing dynasty (c.1722). In any event, there are no similarities between these sherds and the Frolic ceramics.

The Asian Comparative Collection at the University of Idaho in Moscow holds one example of Rocks \& Orchid, one Peach \& Fungus bowl, two Peach \& Fungus sherds, and two Bamboo bowls, all donations with no provenience available. Photographs of the Peach \& Fungus sherds show that, in form, these are more closely related to saucer-plates than bowls. They have a single tier of alternating peach and fungus motifs on the reverse and two tiers of the same alternating motifs on the well and cavetto. One sherd has a catherine wheel in the well. The second sherd is not complete enough to determine what was in the well, however, since the designs on the cavetto appear to have the same arrangement as those on the first example, it is likely that it also possessed a catherine wheel. The only design motif on 
the interior surface of the Frolic Peach \& Fungus is a single ling zhih (fungus) in the well.

\section{Arizona}

Prior to the mid-1870s there were no Chinese documented in Tucson (Lister and Lister 1989:1), however, there is evidence that Chinese ceramics recovered elsewhere in Arizona pre-date that period. Excavation at the Franciscan mission of Awatovi in northeastern Arizona yielded examples of Chinese porcelain (Olsen 1978:8) which are thought to have been brought in by the Spanish who supplied the mission during its existence from 1630 to 1701. Chinese ceramics were also found during excavation of the Tubac Presidio in the south-central Arizona valley of the Santa Cruz River (Olsen 1978:9). Occupation of the Presidio occurred from its early eighteenth century beginnings (c. 1700-1750) until the latter nineteenth century (c. 1850), well before the influx of Chinese into the region. It is thought that these artifacts are trade wares from Mexico (Olsen 1978:9).

Under the Pueblo Center Redevelopment Program a vast urban renewal project was commenced in Tucson in 1968. Archaeological investigations reveal that a diverse ethnic mix over the previous two hundred years included Chinese, Spanish, Mexican, Euro-American, and Black populations (Lister and Lister 1989:ix). Chinese occupation occurred at various points throughout the town of Tucson during the 1870 s and 1880 s, and excavation of sites within the Tucson Urban Renewal Project found Chinese cultural remains consistent with the settlement pattern (Lister and Lister 1989:1-3).

The ceramic assemblage included brown-glazed stoneware food containers; various forms of tableware such as cups, bowls and saucer-plates 
in Four Seasons pattern; a peony-patterned wine pot; and sauce dishes and food containers of various sizes and designs. The most notable of these is a Ginger Jar with a hastily executed underglaze design in the "Canton" motif. In addition, the report illustrates two vessels which are also comparable to Frolic ware (Lister and Lister 1989:49). One is a well-preserved example of a Bamboo rice-soup bowl of which 12 were recovered.

The other, described as a late Qing saucer, appears to be a type resembling the Frolic Snail. As previously described for a similar Riverside vessel, an underglaze design is apparent on the reverse as seen in Figure 44b. (Information describing the underglaze design on the cavetto was not forthcoming). If this is a variety of the Snail type, it and the Riverside vessel would be the only examples found in western United States site collections researched for this study.

Nevada

Construction of Interstate 80 through Lovelock, Nevada brought about archaeological research beginning in 1975 (Hattori, Rusco and Tuohy 1979:1-2). The site began its history as a community in 1866 , but it was not until 1904 that Chinese occupation occurred (Rusco 1979:637). For this reason, the site is less pertinent for comparative purposes since the recovered ceramics are fifty years later than those recovered from the Frolic. Yet, it is interesting to note that types recovered from the Lovelock site are seen in other western assemblages, notably, Celadon, Four Seasons and Bamboo, along with brown-glazed stoneware, polychrome and others. Double Happiness is noticeably absent. 


\section{Discussion}

With the exception of Lovelock, Nevada, all of the western United States sites selected for this review show evidence of Chinese occupancy or trade during the nineteenth century (Figure 45). Among those sites, the first occurrence of Chinese ceramics was at the 1841-42 Estrada Adobe in Monterey, suggesting trade with China. (Monterey was well known at that time as a trading center.) From the mid-1850s in San Jose, Shasta County, Woodland, and Weaverville until the mid-1880's in Riverside, the Chinese were a distinctive presence in the mining and railroad camps and in the workaday activities of the towns in which they lived.

During the 1880 s, many Chinese communities began a decline as racism increased against Chinese immigrants. The Chinese Exclusion Act of 1882, which prohibited Chinese laborers from entering the United States for a period of ten years, added to the decline. Further events occurred to destroy the viability of Chinese communities. Tightly packed and poorly constructed dwellings and businesses were often destroyed by fire, either accidentally or because of arson. All too frequently, when those same communities rebuilt, they were soon again destroyed by fire. Throughout this period, site abandonment also occurred as mines were worked out and railroads were completed, and workers moved on or returned to China due to loss of work.

The archaeological remains of these sites give twentieth century anthropologists a record of the lifeways of these workers and their families. In addition, the ceramic assemblages recovered from these sites offer archaeologists the opportunity to develop typologies, chronologies and area distribution studies for nineteenth century Chinese export ceramics. 
Although Bamboo has been recovered from nearly every California site (except Monterey and Sacramento sites), other Frolic ceramic types are scarcely represented in collections from the western United States (Table 13 and 14; Figure 46). In Monterey, both Peach \& Fungus and Fu appear in the Estrada site, and Peach \& Fungus appears in the Cooper-Molera site. (The unpublished Cooper-Molera collection also contains a wide variety of other Chinese wares, including blue-and-white ceramics of other types.)

There is some evidence that a Snail variety may have been recovered in the Tucson, Arizona, site but it is an isolated occurrence and inconclusive. The fact that no identifiable Snail type sherds were recovered from any sites reviewed here indicates that this type was probably not exported to the United States during the period covered by this study, nor was it being brought over as a personal possession by workers. The Frolic shipment of the Snail type appears to have been an isolated shipment of this blue-and-white export type to California. 


\section{Chapter V CONCLUSION}

Chinese export ceramics, an abundantly manufactured item, were almost always a cargo item on ships from China. In addition to being a source of income for merchants, heavy ceramics packed low in the hold often served as a stabilizing counterbalance for sailing ships. The Frolic ceramics were to be just another shipment of such ceramics, but now, nearly 150 years later, those ceramics have significance beyond cargo or ballast.

This research initially focused on two objectives: development of a typology for the ceramic types from the Frolic shipwreck, and identification of geographic locations around the Pacific Rim, including the western United States, where those types have been recovered. As research progressed, a third objective emerged: establishment of a relative dating scheme based on the frequency of occurrence of ceramic types comparable to Frolic types.

The large size of the Frolic collection, with sufficient specimens to obtain accurate measurements and isolate distinguishing characteristics, made possible the development of a typology for five dominant types of Chinese export ceramics. Chinese ceramics have been recovered from nearly every excavated mid-to-late nineteenth century Chinese community around the Pacific Rim, but because of site disturbance, few examples of complete ceramic vessels are extant, making precise identification of many specimens in those collections difficult. This typology provides a standard nomenclature for future identification of specific Chinese blue-and-white export ceramics. 
Seven clearly identifiable types of blue-and-white ceramics were defined from the Frolic collection. Five of these types were in sufficient quantity to achieve a comprehensive typology: Bamboo, Rocks \& Orchid, Fu, Peach \& Fungus, and Snail. These types were the primary focus of the typology. Two types, Six Treasures and Ginger Jar, had a single representation each, and were sufficiently complete to provide good identification, but they were not central to the typology.

Ceramic types comparable to those from the Frolic have been recovered from sites in Australia, New Zealand, The Philippines, Malaysia, Indonesia, and Vietnam in Southeast Asia and the South Pacific. Furthermore, those same ceramic types have been recovered from United States sites in California, Arizona, and Nevada. Although a considerable amount of research has been done on nineteenth century Chinese communities in California, more remains to be done. As archaeologists further investigate these communities and workers' camps, additional types of blue-and-white export ceramics will undoubtedly be identified.

Comparison of the Frolic collection with western United States site collections facilitated the development of a relative chronology for those ceramics. At first glance it appeared that the Frolic cargo may represent a defining event in the chronology of blue-and-white export ceramics (Figure 47), but the presence of two types, Peach \& Fungus and Fu, before and after 1850 contradicts that assumption. Peach \& Fungus and Fu were recovered from two pre-1850 sites in Monterey, and these same two types are seen again at San Jose and at China Camp in San Francisco (Peach \& Fungus) and at Marysville (Fu) after 1850. 
There is, however, a clearly defined presence of Rocks \& Orchid and Bamboo at post-1850 sites. In the western United States, Rocks \& Orchid was recovered from the 1852-57 San Jose site and the 1885-93 Riverside site. From the 1860s onward, Bamboo was the Frolic type most commonly seen in collections from overseas Chinese worker sites. Interestingly, although the Bamboo type and Double Happiness rice bowls are the most frequently recovered blue-and-white ceramics from post-1850 sites, no Double Happiness was found with the Frolic's cargo.

The Snail type has not been recovered at any site in the western United States, either before or after 1850. Perhaps that type was a one-time order from a specific supplier?

Archaeological collections around the western Pacific Rim reveal a similar sequence of occurrence as those in the United States. Peach \& Fungus sherds were recovered from Australian sites prior to 1850, but are not present in later sites. In Australian and New Zealand sites post-dating 1850, Bamboo is the dominant type.

Elsewhere, the Rocks \& Orchid and Peach \& Fungus types were recovered from Malaysia, and possibly from The Philippines. Informants reported that Fu and Snail are present in museum collections. However, without photographic proof, it is uncertain whether those vessels are identical to, or varieties of, the Frolic types. These types were mentioned without reference to specific dates.

The Peach \& Fungus type virtually disappeared in the latter half of the nineteenth century, with two exceptions (San Jose and San Francisco), at or near the port of entry of Chinese export goods. Yet, Peach \& Fungus has 
been seen by travelers in Southeast Asia as recently as the past decade and this author purchased several examples of Peach \& Fungus plates at antique shops during 1990-92. All are nineteenth century and were most probably imported as antiques since the opening of China during the last decade. Perhaps this design motif fell out of favor as an export product, or was no longer produced by a particular kiln or guild. Perhaps it was associated with a shift in consumer tastes and no longer contracted for by merchants and shipping companies. Devolved patterns of this type are abundantly available in contemporary shops; is this a deliberate revival of the type? Peach \& Fungus has a long tradition in Chinese blue-and-white ceramic history and it seems reasonable that the design would reappear.

While a clear chronology for all types has not been conclusively established, a surprising observation was made when the types were plotted geographically within California. Peach \& Fungus and Fu are clearly dominant in the southern half of the state, south of San Francisco, with some Bamboo seen occasionally. North of San Francisco, Bamboo is the dominant type, with one instance of Fu occurring (in Marysville). This phenomenon could reflect a shift in consumer taste. Mining activity and railroad construction was more concentrated in northern California in the post- 1850 era. Perhaps the needs of the thousands of Chinese workers who arrived during this period were met by this small, easily carried, Bamboo bowl.

Research questions remain to be addressed, and future study could include the following:

1. Determination of locations in China where Frolic ware was produced, and comparison of those locations with contemporary production sites. 
2. Chemical analysis of Frolic ware body fabric to determine clay composition and provide data for comparison with the same types recovered from Pacific Rim sites, to determine whether they came from a common clay source.

3. Further investigation of collections in Southeast Asia and the South Pacific to search for the elusive Snail, a type which seems to be isolated in time and place, and which could possibly serve as a time marker.

4. Investigation of sites in western Canada, northwestern United States, western Mexico, and Central and South America, to further determine the geographic and temporal distribution of Frolic types in the Western Hemisphere.

The mid-nineteenth century saw a shift in the kinds of trade goods exported from China to the western United States. At first, the increased wealth and purchasing power of California's growing Euro-American and Hispanic citizenry presented a built-in market for imported goods from China. Then a shift occurred, brought about by changes in the demographics of Gold Rush California and a burgeoning population of Chinese workers, who created a demand for a different kind of Chinese merchandise. Cargo intended for the predominantly Hispanic and Euro-American citizen of the pre-1850 era was replaced by cargo intended to serve the Chinese immigrant worker of the post-1850 period. It may be that this change in demographics corresponded to the change in ceramic types characterizing pre- and post-Frolic eras, and the Frolic ceramics represent a transitional cargo. 


\section{REFERENCES}




\section{REFERENCES}

\section{Personal Communications}

Antolinez, Fr. Jesus Ma. Merino

1991 Former Director, Santo Tomas Museum, University of Santo

Tomas, Manila, Republic of The Philippines.

Bell, Peter

1991 Senior Heritage Officer, State Heritage Branch, Department of Environment and Planning, Adelaide, South Australia.

Bhattacharya, R. K.

1991 Deputy Director, Anthropological Survey of India, Calcutta, India.

Casal, Gabriel S.

1991 Director, National Museum, Manila, Republic of the Philippines.

Crawford, Ian

1990

Head, Division of Human Studies, Western Australian Museum, Perth, Western Australia.

Flynn, Katherine and William Roop 1990 Archaeological Resource Service, Petaluma, California.

Foo, Jimmy

1991 Sabah Museum and State Archives, Sabah, Malaysia.

Ganse, Shirley H.

1991 Museum Services, Mercer Island, Washington.

Guy, John

1991 Deputy Curator, Indian and Southeast Asian Collection, Victoria and Albert Museum, London.

Ho, Chuimei

1991 Research Associate, Field Museum of Natural History, Chicago, Illinois. 
Kaboy, Tuton

1992

Kao, Arthur

1990 Professor of Art History, Department of Art, San Jose State University, San Jose, California.

Kwan, Stephen

1990

Sarawak Museum, Sarawak, Malaysia.
Hong Kong-born; speaks and reads Cantonese; Professor of Management Information Systems, College of Business, San Jose State University, San Jose, California.

Layton, Thomas $\mathbf{N}$.

1991-2 Professor of Anthropology, Department of Anthropology, San Jose State University, San Jose, California.

Leibrick, Fiona

1991

Curator, Southeast Asian Material Culture, Museums and Art

Galleries of the Northern Territory, Darwin, Northern

Territory.

Lengyel, Alfonz

1991 Fudan Museum Foundation, Ambler, Pennsylvania.

Leong, Wing $\mathrm{K}$.

1991 Graduate of New Asia College, Chinese University of Hong

Kong. Author and teacher of Chinese painting. Chinese Art Studio, Portland, Oregon.

Leung, Kai-Cheong

1990 Professor of Chinese, Department of Foreign Languages, San

Jose State University, San Jose, California.

Macknight, Campbell C.

1991 Senior Lecturer, History Department, The Faculties, Australian National University, Canberra, Australia. 
McCarthy, Justin

1991 Consultant in Historical Archaeology, Austral Archaeology, Adelaide, South Australia.

Author: Would-be Diggers and Old Travellers: The Chinese at the Union Reefs and the 12 Mile in the Northern

Territory, 1876-1910. National Trust of Australia, 1989.

Ngerntongdee, Roxanna Brown

1991 Author: The Ceramics of South-east Asia, Their Dating and Identification. Suthep, Chiang Mai, Thailand.

Ritchie, Neville A.

1991

Regional Archaeologist, Department of Conservation, Hamilton, New Zealand.

Author: Archaeology and history of the Chinese in southern New Zealand during the nineteenth century: A study of acculturation, adaptation, and change. Ph.D. dissertation, University of Otago, Dunedin, New Zealand, 1986.

Scheans, Daniel

1991 Retired Professor of Anthropology, Ceramics Analysis

Laboratory, Portland State University, Portland, Oregon.

Schulz, Peter D.

1992 Senior State Archaeologist, California Department of Parks and Recreation, Sacramento, California.

1992 Author: Archeological investigations at China Camp village, China Camp State Park. ms. on file. Resource Protection Division, California Department of Parks and Recreation, Sacramento, California.

Steele, Harvey W.

1991 Art and Artifact Specialist, United States Customs Office, Portland, Oregon.

Author: Abundant protuberances: the iconography of 19th century ceramics at archaeological sites in the Pacific Northwest. ms. in author's possession. Ceramic Analysis Laboratory, Portland State University, Portland, Oregon. 
Wei, Anna

1991 Chinese-born; speaks and reads Mandarin; holds Master's degree in Library Science, San Jose State University, San Jose, California.

Wei, Ming Jia

1990 Chinese archaeologist and candidate for Ph. D. in archaeology, James Cook University, North Queensland, Australia.

Yatim, Othman

1991 Senior Assistant Director of Archaeology, National Museums, Kuala Lumpur, Malaysia.

\section{Published Sources}

Beals, Herbert K. and Harvey Steele

1981 Chinese Porcelains from Site 35-TI-1, Netarts Sand Pit, Tillamook County, Oregon. University of Oregon Anthropological Papers, No. 23, Eugene, Oregon.

Benté, Vance G. 1987

Ceramics, Appendix A. In Dutch Gulch Lake: Excavation at Thirteen Historic Sites in the Cottonwood Mining District. Cottonwood Creek Project, Shasta and Tehama Counties, California. U. S. Army Corps of Engineers, Sacramento District.

1985 Analysis of the ceramic sub-assemblage recovered from the Estrada Adobe. In The Archaeological Investigations at CAMNT-1243H The Estrada Adobe in Monterey, California.

San Jose: Archaeological Resource Management.

1976 Good luck, long life. In The Changing Faces of Main Street, by Roberta S. Greenwood. Ventura Mission Plaza Archaeological Project, City of San Buenaventura Redevelopment Agency, Ventura, California.

Brott, Clark W.

1982a Moon Lee One: Life in Old Chinatown, Weaverville, California. Redding, California: Great Basin Foundation. 
1982b The rice was served in celadon, the opium came packed in brass. In Moon Lee One: Life in Old Chinatown, Weaverville, California. Redding, California: Great Basin Foundation.

Burling, Judith and Arthur Hart Burling

1953 Chinese Art. New York: Bonanza Books.

Chace, Paul G.

1976 Overseas Chinese ceramics. In The Changing Faces of Main Street, by Roberta S. Greenwood. Ventura Mission Plaza Archaeological Project, City of Buenaventura Redevelopment Agency, Ventura, California.

Chinn, Thomas W., ed.

1973 A History of the Chinese in California: A Syllabus. San Francisco: Chinese Historical Society of America.

Costello, Julia G. and Mary L. Maniery

1987 Rice Bowls in the Delta: Artifacts Recovered from the 1915 Asian Community of Walnut Grove, California. Occasional Paper 16, Institute of Archaeology. Los Angeles: University of California.

Dotta, James and Clark W. Brott

1982 Salvaging the history of the Chinese-American pioneers. In Moon Lee One: Life in Old Chinatown, Weaverville, California, by Clark W. Brott. Redding, California: Great Basin Foundation.

Felton, David L. and Peter D. Schulz

1983 The Diaz collection: material culture and social change in mid-nineteenth century Monterey. California Archaeological Reports, No. 23. Sacramento: California Department of Parks and Recreation.

Felton, David L., Frank Lortie and Peter D. Schulz

1984 The Chinese laundry on Second Street: archaeological investigations at the Woodland Opera House site. California Archaeological Reports, No. 24. Sacramento: California Department of Parks and Recreation. 
Fischell, Rosalind

1987 Blue \& White China: Origins and Western Influences.

Boston: Little Brown.

Ganse, Shirley $\mathrm{H}$.

1984 Chinese Ceramics: Art and Technology. High Museum of

Art, Atlanta. November 19, 1984-February 24, 1985.

Garner, Sir Henry

1977 Oriental Blue and White. Reprint of 1970 ed. London:

Faber and Faber.

Glathe, A.

1932 Die Chinesischen Zahlen (The Chinese Numbers). German

Institute for Nature \& Social Sciences, East Asia 26(B).

Verlag Asia Major G.M.B.H., Leipzig.

Hanover, Rita

1982 The Chinese of Trinity County. In Moon Lee One: Life in Old Chinatown, Weaverville, California, by Clark W. Brott. Redding: Great Basin Foundation.

Hattori, Eugene M., Mary K. Rusco and Donald R. Tuohy

1979 Archaeological and Historical Studies at Ninth and Amherst, Lovelock, Nevada. Vol. I. Nevada State Museum Archaeological Services, Carson City, Nevada.

Henderson, Graeme

1973 The Wreck of the "Elizabeth." Studies in Historical Archaeology, No. 1. Sydney, Australia.

Ho, Chuimei

1988 Minnan blue-and-white wares: An archaeological survey of kiln sites of the 16th-19th centuries in southern Fujian,

China. BAR International Series 428.

1987 Minnan blue and white wares. In Style in the East Asian Tradition ed. by Rosemary E. Scott and Graham Hutt. Colloquies on Art \& Archaeology in Asia No. 14, Percival David Foundation of Chinese Art. School of Oriental and African Studies, University of London, England. 
Hobson, R. L.

1976 Chinese Pottery and Porcelain. 2 vols. in 1. Reprint of 1915 ed. New York: Dover Press.

Jack, Ian, Kate Holmes and Ruth Kerr

1984 Ah Toy's garden: a Chinese market-garden on the Palmer River goldfield, North Queensland. In Australian Historical Archaeology, 2, n.p.

Kerr, Rose

1986 Chinese Ceramics: Porcelain of the Qing Dynasty, 16441911. Victoria and Albert Museum, Far Eastern Series. London: Precision Press.

Kwan, K. K. and Jean Martin

1985 Kitchen Ch'ing: A Ceramic Legacy of Asia's Maritime Trade. Southeast Asia Ceramic Society. Kuala Lumpur: Oxford University Press.

Laffey, Glory Anne, Vance Benté, Robert Cartier, Edna Kimbro and Charlene Detlefs

1985 The Archaeological Investigations at CA-MNT-1243H, The Estrada Adobe in Monterey, California. Archaeological Resource Management, San Jose, California.

Laffey, Glory Anne and Edna Kimbro

1985 Historic background. In The Archaeological Investigations at CA-MNT-1243H, The Estrada Adobe in Monterey, California. Archaeological Resource Management, San Jose, California.

Lam, Peter Y. K., John Carswell, Tristan Russell, Mohd.Mokhtar bin Abu Bakar, K. K. Kwan and Jean Martin

1985 A Ceramic Legacy of Asia's Maritime Trade: Song dynasty Guangdong wares and other 11th to 19th century trade ceramics found on Tioman Island, Malaysia. Southeast Asian Ceramic Society, West Malaysia Chapter. Kuala Lumpur. 
Layton, Thomas $\mathbf{N}$.

n.d. Drug Runner: The Story of New England Merchants and the "Frolic," a Baltimore-Built Opium Clipper in India, China and Gold Rush California. Unpublished manuscript in author's possession.

1990 Western Pomo Prehistory: Excavations at Albion Head, Nightbirds' Retreat, and Three Chop Village, Mendocino County, California. Monograph 32, Institute of Archaeology. Los Angeles: University of California.

Lenz, Frank B. 1920

The world's ancient porcelain center. In The National Geographic Magazine 38(5):391-406. National Geographic Society, Washington, D. C.

Leong, Wing $\mathbf{K}$. 1974

Chinese Painting Step by Step. n.p., Portland, Oregon.

Little, Stephen 1983

Chinese Ceramics of the Transitional Period: 1620-1683. China House Institute in America, New York.

1990 Narrative themes and woodblock prints in the decoration of seventeenth-century Chinese porcelains. In SeventeenthCentury Chinese Porcelain from the Butler Family Collection by Sir Michael Butler, Margaret Medley and Stephen Little. Art Services International, Alexandria, Virginia.

Lister, Florence C. and Robert H. Lister 1989 The Chinese of Early Tucson: Historic Archaeology From the Tucson Urban Renewal Project. Anthropological Papers of the University of Arizona, No. 52. Tucson: University of Arizona Press.

Maust, Don A., ed.

1973 Collectable Chinese Art and Antiques. Uniontown, Pennsylvania: E. G. Warman Publishing, Inc.

McCarthy, Justin

1986 Pine Creek Heritage Zone Archaeological Survey. National Trust of Australia, n.p. 
McIlroy, Jack

1988 An Archaeological Survey of the Asian Quarter of Cossack. Australian Heritage Commission, National Estate Programme Grant, n.p.

Medley, Margaret

1976 The Chinese Potter: A Practical History of Chinese

Ceramics. Ithaca, New York: Cornell University Press.

Mudge, Jean McClure

1986 Chinese Export Porcelain in North America. New York: Clarkson N. Potter, Inc.

Mueller, Fred W., Jr.

1987 Asian Tz'u: porcelain for the American market. In Wong Ho Leun, An American Chinatown, Vol. 2. Great Basin Foundation, San Diego, California.

National Trust of Australia

n.d. Early Days in Pine Creek. Alice Springs, Northern Territory, Australia.

Neave-Hill, W. B. R.

1975 Chinese Ceramics. London: Bartholomew \& Son.

Nelson, Glenn C.

1966 Ceramics: A Potter's Handbook (2nd ed.). New York:

Holt, Rinehart \& Winston.

Olsen, John W.

1978 A study of Chinese ceramics excavated in Tucson. In The Kiva, Vol. 44, No. 1. Arizona Archaeological and Historical Society, Tucson, Arizona.

Parmelee, Cullen W.

1951 Ceramic Glazes. Chicago, Illinois: Industrial Publications, Inc.

Pastron, Allen G.

1981 Behind the Seawall: Historical Archaeology Along the San Francisco Waterfront, Vol. 2. Archeo-Tec for San Francisco Clean Water Program. 
Praetzellis, Mary and Adrian Praetzellis

1982 Archaeological and Historical Studies of the IJ56 Block, Sacramento, California: An Early Chinese Community. Cultural Resources Facility, Sonoma State University, Rohnert Park, California.

Ritter, Eric W. 1986

The Historic Archaeology of a Chinese Mining Venture Near Igo in Northern California. Bureau of Land Management, Cultural Resources Report, Archaeology, Redding, California.

Rusco, Mary K.

1979

Summary and discussion. In Ninth and Amherst, Lovelock, Nevada, Vol. I. Nevada State Museum Archaeological Services, Carson City, Nevada.

Sando, Ruth Ann and David L. Felton.

1987 Inventory Records of Ceramics and Opium From a Nineteenth Century Chinese Store in California. California Department of Parks and Recreation, Archaeological Laboratory, Sacramento, California.

Schiffer, Herbert, Peter Schiffer and Nancy Schiffer

1975 Chinese Export Porcelain: Standard Patterns and Forms, 1780 to 1880. West Chester, Pennsylvania: Schiffer Publishing, Ltd.

Smith, Robert E., Gordon R. Willey and James C. Gifford 1960 The type-variety concept as a basis for the analysis of Maya pottery. In American Antiquity, Vol. 25, No. 3. Society for American Archaeology. Salt Lake City: University of Utah Press.

Stenger, Alison T.

1992 The universal overseas site: a predictable ceramic assemblage. In Asian Comparative Collection Newsletter, 9(1), March. Asian Comparative Collection, University of Idaho, Moscow, Idaho. 
Sze, Mai Mai

1959 The Way of Chinese Painting: Its Ideas and Technique. New York: Random House.

Terrey, Paula B. and Allen G. Pastron

1990 Chinese export porcelain in gold rush San Francisco. In The Hoff Store Site and Gold Rush Merchandise From San Francisco, California, by Allen G. Pastron and Eugene M. Hattori, eds. Special Publication Series, No. 7. Society for Historical Archaeology, Pleasant Hill, California.

Tordoff, Judith D.

1987 Dutch Gulch Lake: Excavation at Thirteen Historic Sites in the Cottonwood Mining District. Cottonwood Creek Project, Shasta and Tehama Counties, California. U. S. Army Corps of Engineers, Sacramento District.

Wegars, Priscilla 1985, 1986, 1987

Chinese Artifact Inventory, Asian Comparative Collection, Laboratory of Anthropology, University of Idaho, Moscow, Idaho.

Willetts, William and Lim Suan Poh

1981 Nonya Ware and Kitchen Ch'ing: Ceremonial and Domestic Pottery of the 19th-20th Centuries Commonly Found in Malaysia. The Southwestern Asian Ceramic Society, West Malaysia Chapter. Oxford University Press.

Williams, C. A. S.

1988 Chinese Symbolism and Art Motifs. 3rd rev. ed., Rutland, Vermont: Charles E. Tuttle Co., Inc.

Wlodarski, Robert J.

1976 A brief history of Chinatown in Ventura. In The Changing Faces of Main Street by Roberta S. Greenwood. Ventura Mission Plaza Archaeological Project, City of Buenaventura Redevelopment Agency, Ventura, California.

Yeo, S. T., and Jean Martin

1978 Chinese Blue \& White Ceramics. Southeast Asian Ceramics Society. Arts Orientalis, Singapore. 
TABLES 


\begin{tabular}{||l|l|c|c||}
\hline \multicolumn{3}{||l|}{ Table 1. Donors of Frolic Ceramics to MEN-1914-H Collection } \\
\hline $\begin{array}{l}\text { Catalog } \\
\text { Number }\end{array}$ & Donor Name & Sherd Count & $\%$ of Total \\
\hline 1 and 2 & Dale Hartesveldt & 27 & 3.6 \\
4 & David Buller & 84 & 11.3 \\
5 & Patrick Philpot & 7 & 0.9 \\
6 & Larry Pierson & 334 & 44.8 \\
7 & James Kennon & 37 & 5.0 \\
8 & Cliff Craft & 3 & 0.4 \\
9 & Pat Gibson & 38 & 5.1 \\
10 & Steve Buller & 1 & 0.1 \\
11 & Paul Selchau & 148 & 19.9 \\
12 & S.J.S.U.* & 63 & 8.5 \\
& Louis Fratis & 3 & 0.4 \\
\hline \multicolumn{4}{|l|}{} \\
\hline
\end{tabular}




\begin{tabular}{|c|c|c|c|c|}
\hline Specimen & $\begin{array}{l}\text { Sherd } \\
\text { Count }\end{array}$ & $\%$ of Total & MNV & $\%$ of Total \\
\hline $\begin{array}{l}\text { Major Type } \\
\text { Rocks \& Orchid }\end{array}$ & 71 & 10.0 & 24 & 13.5 \\
\hline Bamboo & 35 & 4.8 & 10 & 5.6 \\
\hline Peach \& Fungus & 145 & 20.0 & 44 & 24.7 \\
\hline $\mathbf{F u}$ & 64 & 8.8 & 14 & 7.9 \\
\hline Snail & 188 & 26.0 & 82 & 46.1 \\
\hline $\begin{array}{l}\text { Unidentifiable sherds } \\
\text { of above } 5 \text { types }\end{array}$ & 153 & 21.1 & -- & --- \\
\hline $\begin{array}{l}\text { Minor Type } \\
\text { Six Treasures }\end{array}$ & 1 & 0.1 & 1 & 0.6 \\
\hline Ginger Jar & 5 & 0.7 & 1 & 0.6 \\
\hline $\begin{array}{l}\text { Untyped } \\
\text { Misc. blue-and-white } \\
\text { (no type name) }\end{array}$ & 8 & 1.1 & 2 & 1.1 \\
\hline Brown-glazed ware & 11 & 1.5 & $\cdots$ & $-\cdots$ \\
\hline Finial & 1 & 0.1 & --- & -- \\
\hline Lid & 1 & 0.1 & -- & $\cdots$ \\
\hline Teapot Spout & 1 & 0.1 & --- & --- \\
\hline $\begin{array}{l}\text { Staffordshire } \\
\text { (English) }\end{array}$ & 28 & 3.9 & -- & $\cdots$ \\
\hline \multirow[t]{2}{*}{$\begin{array}{l}\text { Misc. unidentified } \\
\text { sherds }\end{array}$} & 13 & 1.8 & -- & --- \\
\hline & 725 & & 178 & \\
\hline
\end{tabular}




\begin{tabular}{|c|c|c|c|c|c|c|c|c|c|}
\hline Type or Variety & $\begin{array}{l}\text { Base } \\
100 \%\end{array}$ & $\begin{array}{l}\text { Base } \\
\text { 50\%+ }\end{array}$ & $\begin{array}{l}\text { Busal } \\
\text { Sherd }\end{array}$ & $\begin{array}{l}\text { Body } \\
\text { Sherd }\end{array}$ & $\begin{array}{c}\text { Rim } \\
\text { Sherd }\end{array}$ & $\begin{array}{l}\text { Type } \\
\text { Total }\end{array}$ & MNV & $\begin{array}{c}0 \text { MNV } \\
\text { to Type } \\
\text { Total } \\
\end{array}$ & \begin{tabular}{|c|}
$\%$ MNV \\
to \\
Total
\end{tabular} \\
\hline Rocks \& Orchid Type & 12 & 12 & 35 & 1 & 11 & 71 & 24 & 33.8 & 3.7 \\
\hline Bamboo Type & -- & 10 & 6 & 6 & 13 & 35 & 10 & 28.6 & 1.5 \\
\hline Peach \& Fungus Type & 28 & 16 & 25 & 53 & 23 & 145 & 44 & 30.3 & 6.7 \\
\hline Fu Type & 6 & 8 & 44 & 4 & 2 & 64 & 14 & 21.9 & 2.1 \\
\hline \multicolumn{10}{|l|}{ Snail Type: } \\
\hline Var. A & 5 & 6 & $\cdots$ & --- & 17 & 28 & 11 & 39.3 & 1.7 \\
\hline Var. B & 1 & 9 & $\cdots$ & $\cdots$ & --- & 10 & 10 & 100.0 & 1.5 \\
\hline Var. C & 2 & 7 & -- & $\cdots$ & $\cdots$ & 9 & 9 & 100.0 & 1.4 \\
\hline Var. D & 7 & 3 & 5 & $\cdots$ & $\cdots$ & 15 & 10 & 66.7 & 1.5 \\
\hline Var. E & 7 & 33 & 31 & -.. & $\cdots$ & 71 & 40 & 56.3 & 6.1 \\
\hline Var. A, B, or C & 1 & 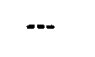 & 20 & $\cdots$ & $\ldots$ & 21 & 1 & 4.8 & 0.2 \\
\hline Var. A, B, C, D, or E & $\cdots$ & 1 & -- & 11 & ... & 12 & 1 & 8.3 & 0.2 \\
\hline Var. B, C, D, or E & $\cdots$ & $\cdots$ & $\cdots$ & $\cdots$ & 22 & 22 & $\cdots$ & $\cdots$ & $\cdots$ \\
\hline $\begin{array}{l}\text { Unidentifiable sherds } \\
\text { of above types }\end{array}$ & $\cdots$ & $\cdots$ & 20 & 97 & 36 & 153 & $\cdots$ & $\cdots$ & $\cdots$ \\
\hline TOTAL & 69 & 105 & 186 & 172 & 124 & 656 & 174 & & \\
\hline
\end{tabular}


Table 4. Notes on Analysis, Typology, and Measurements

1. Rocks \& Orchid - usual double band of underglaze surrounding central motif is missing:

Catalog No. 3-31.

2. Bamboo - measurements of wall thickness taken at point of upper double band:

Catalog Nos. 8-24, 3-16, 3-17/21, 8-25, 11-4, 10-126, 5-409, 5-101.

3. Fu - basal sherds have central "nipple" but no footring. Counted as two MNV:

Catalog Nos. 5-221, 10-96.

4. Fu - measurements of central underglaze band (medallion) were taken inside the band:

Catalog Nos. 6-23, 10-66, 6-24, 6-25, 3-47, 3-46, 10-68, 3-48, 10-67.

5. Fu - measurements of wall thickness taken $2.5 \mathrm{~cm}$ below the rim: Catalog Nos. 6-23, 6-24, 10-66.

6. Snail, Variety A, B, and E - have "tally marks" on the following: Catalog Nos. 3-50, 5-1, 5-3, 10-22, 10-26, 10-35, 10-37, 10-38, 10-41, $10-72,10-80$, and 11-6,

7. Snail, Variety unknown - basal sherd has no footring, but does have central "nipple." Counted as one MNV:

Catalog No. 5-143.

8. Snail, Variety D - central band diameter is unusually large for this variety:

Catalog No. 5-9.

9. Snail, Variety E - usual double banding occurs here as a single band: Catalog No. 10-17. 
Table 5. Color Values for Five Types of Frolic Ware

\begin{tabular}{|c|c|c|c|}
\hline Type & Clay Body & Underglaze & Glaze \\
\hline Rock \& Orchid & $5 N 9 / 0$ & 5PB $3 / 10$ & $-\cdots$ \\
\hline Bamboo & $5 N 8 / 0$ & SPB $3 / 8-4 / 4$ & $5 \mathrm{~N} 9 / 0$ \\
\hline Peach \& Fungus & $5 \mathrm{~N} 9 / 0$ & SPB $3 / 8-3 / 12$ & --- \\
\hline $\mathbf{F u}$ & $5 N 8 / 0$ & SPB $7 / 1$ & $5 \mathrm{~N} 8 / 0$ \\
\hline Snail, Variety A & $5 Y 9 / 1$ & $2.5 \mathrm{~B} \quad 3 / 6-4 / 6$ & $2.5 \mathrm{~PB} 8 / 2$ \\
\hline Snail, Variety B & $2.5 \mathrm{~N} 8 / 0$ & $2.5 \mathrm{~B} 3 / 2-4 / 2$ & $2.5 \mathrm{~N} 7 / 0$ \\
\hline Snail, Variety C & $2.5 \mathrm{~N} 9 / 0$ & $2.5 \mathrm{~PB} 4 / 4$ & $\cdots$ \\
\hline Snail, Variety D & $2.5 \mathrm{~N} 9 / 0$ & $2.5 \mathrm{~PB} 3 / 6$ & $\cdots$ \\
\hline Snail, Variety E & $\cdots$ & $7.5 \mathrm{~PB} 4 / 4$ & $2.5 \mathrm{~PB} 8 / 2$ \\
\hline
\end{tabular}

Note: 1. Values were determined with dry sherds under fluorescent lighting.

2. Values are from Munsel Book of Color. Opposite Hue Edition. Baltimore: Munsell Color Company, Inc., 1950. 


\begin{tabular}{|c|c|c|}
\hline Type & Vessel Form & Clay Body \\
\hline Rocks \& Orchid & Saucer-dish & $\begin{array}{l}\text { Porcelaneous } \\
\text { Stoneware }\end{array}$ \\
\hline Bamboo & $\begin{array}{c}\text { Small rice } \\
\text { bowl }\end{array}$ & $"$ \\
\hline Peach \& Fungus & $\begin{array}{l}\text { Large rice } \\
\text { bowl }\end{array}$ & $"$ \\
\hline Fu & $\begin{array}{c}\text { Family soup } \\
\text { bowl }\end{array}$ & $"$ \\
\hline \multicolumn{3}{|l|}{ Snail } \\
\hline Variety A & Soup plate & $"$ \\
\hline Variety B & $"$ & $"$ \\
\hline Variety $\mathbf{C}$ & $"$ & $"$ \\
\hline Variety D & $"$ & $"$ \\
\hline Variety E & $"$ & $"$ \\
\hline Six Treasures & Saucer-dish & $"$ \\
\hline Ginger Jar & Ginger jar & $"$ \\
\hline
\end{tabular}




\begin{tabular}{||l|l||}
\hline \multicolumn{1}{||l}{ Table 7. Analysis of Well and Cavetto Design Motifs on Rocks \& Orchid } \\
Type.
\end{tabular}


Table 7. (Cont.) Analysis of Well and Cavetto Design Motifs on Rocks \& Orchid Type.

\begin{tabular}{|c|c|}
\hline Catalog Number & Comments \\
\hline $3-116$ & $\begin{array}{l}\text { Heavily encrusted with iron oxide stain; most } \\
\text { complete example in collection, missing only } \\
\text { a small wedge }(1 \times 6 \mathrm{~cm}) \text { and three rim chips; } \\
\text { water design has three loops and no apparent } \\
\text { tail. }\end{array}$ \\
\hline $5-272 ; 5-277 ; 8-4$ & $\begin{array}{l}5-272 \text { and } 8-4 \text { have the same orchid detail } \\
\text { painted with loose, free brush strokes; these } \\
\text { appear to have been signed by the same hand. }\end{array}$ \\
\hline $5-278 ; 10-123$ & $\begin{array}{l}\text { These are painted with a loose brush stroke; } \\
\text { not as precisely drawn as some other vessels; } \\
\text { characters on the reverse are bolder than } \\
\text { those on above group. }\end{array}$ \\
\hline $6-12$ & $\begin{array}{l}\text { Design is heavy; underglaze blurry; water has } \\
\text { three loops but line is short; water has a tail. }\end{array}$ \\
\hline $8-3 ; 10-121$ & Concretion obscures most of the design. \\
\hline $8-8$ & $\begin{array}{l}\text { Basal fragment; not enough design for } \\
\text { comparison. }\end{array}$ \\
\hline $8-10 ; 10-125$ & Fragments too small to compare with others. \\
\hline $8-13$ & $\begin{array}{l}\text { Base and rim fragment; not enough design to } \\
\text { compare, although prunus is large and full in } \\
\text { each sherd. }\end{array}$ \\
\hline $10-124$ & Partial base/rim sherd. \\
\hline
\end{tabular}




\begin{tabular}{||l|l||}
\hline \multicolumn{2}{||l||}{ Table 8. Analysis of Base and Exterior Wall of Rocks \& Orchid Type. } \\
\hline $\begin{array}{l}\text { Catalog } \\
\text { Number }\end{array}$ & Comments \\
\hline $3-23$ & $\begin{array}{l}\text { Has no underglaze band around inside of footring; this } \\
\text { missing feature is common to the following vessels: No.'s } \\
3-25,3-26,3-27,3-116,5-84,5-272 / 3,5-277,5-278,5- \\
413,5-414,6-12,8-3,8-4,8-5,10-123, \text { and 10-124. }\end{array}$ \\
$3-31$ & $\begin{array}{l}\text { Has no underglaze band at junction of well and cavetto; all } \\
\text { others in the collection have a double band at this } \\
\text { location. Was this missed on the production line? }\end{array}$ \\
$\begin{array}{l}\text { Has no underglaze band around inside of footring; vessel } \\
\text { shape is flat and thinly potted in relation to others of this } \\
\text { type; thickness of base is less than 0.4 cm; this vessel is } \\
\text { unusual in that there is no variation in thickness from rim } \\
\text { to center of base. }\end{array}$ \\
\hline
\end{tabular}




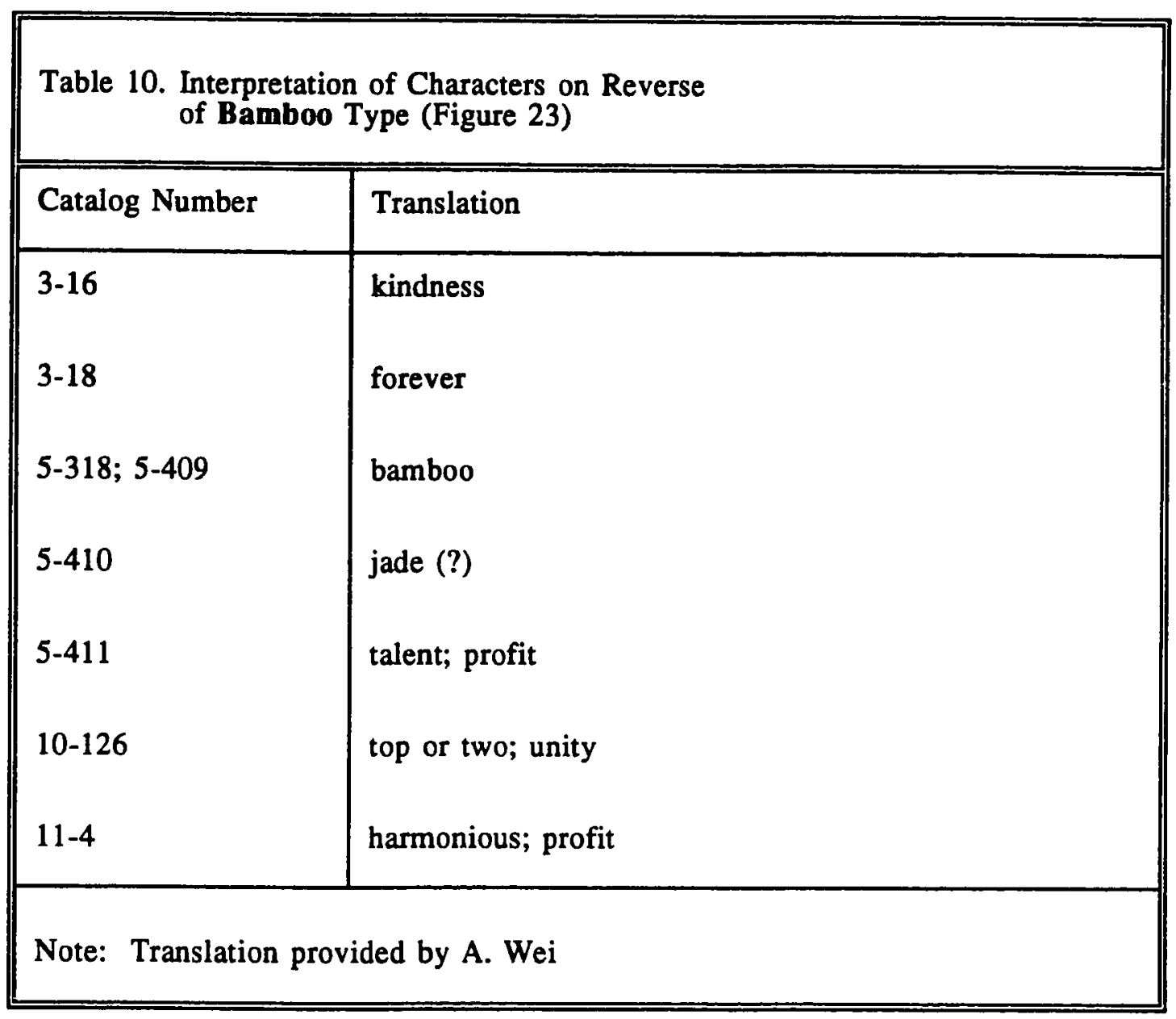




\begin{tabular}{|c|c|c|c|}
\hline $\begin{array}{l}\text { Catalog } \\
\text { Number }\end{array}$ & $\begin{array}{l}\text { Type or } \\
\text { Variety }\end{array}$ & $\begin{array}{l}\text { Mark or } \\
\text { Number }\end{array}$ & $\begin{array}{l}\text { Number of } \\
\text { Sherds }\end{array}$ \\
\hline $5-1 ; 5-3$ & $\begin{array}{c}\text { Snail } \\
\text { Variety A }\end{array}$ & 1 & 2 \\
\hline $10-26$ & $" \quad B$ & 1 & 1 \\
\hline $10-37 ; 10-38$ & $" E$ & 1 & 2 \\
\hline $3-50 ; 10-35$ & $" \quad E$ & 2 & 2 \\
\hline $10-41 ; 11-6$ & " $\quad E$ & 5 & 2 \\
\hline $10-22$ & " $E$ & ? (partial) & 1 \\
\hline $10-72$ & $\mathbf{F u}$ & 1 & 1 \\
\hline $10-80$ & $\mathbf{F u}$ & 1 & 1 \\
\hline
\end{tabular}


Table 12. Distribution of Five Frolic Ware Types in Pacific Rim Sites

\begin{tabular}{|c|c|c|c|c|c|}
\hline & $\begin{array}{c}\text { Rocks \& } \\
\text { Orchid }\end{array}$ & Bamboo & $\begin{array}{l}\text { Peach \& } \\
\text { Fungus }\end{array}$ & $\mathrm{Fu}$ & Snail \\
\hline The Philippines & $X(?)^{*}$ & -. & --- & -- & --- \\
\hline New Zealand & --- & $\mathbf{x}$ & $\cdots$ & -- & -.. \\
\hline Australia & -.. & $\mathbf{x}$ & $\mathbf{x}$ & --- & $X(?)^{*}$ \\
\hline Indonesia & --- & --- & $\cdots$ & $\mathbf{x}$ & --- \\
\hline Malaysia & $\mathbf{x}$ & $\mathbf{x}$ & $\mathbf{x}$ & $\mathrm{X}$ & $\mathrm{x}$ \\
\hline
\end{tabular}

* Identification of these types is uncertain 


\begin{tabular}{|c|c|c|c|c|c|}
\hline Site & $\begin{array}{l}\text { Rocks \& } \\
\text { Orchid }\end{array}$ & Bamboo & $\begin{array}{l}\text { Peach \& } \\
\text { Fungus }\end{array}$ & $\mathrm{Fu}$ & Snail \\
\hline $\begin{array}{c}\text { California } \\
\text { Ventura }\end{array}$ & --- & $17 / 219$ & --- & --. & --- \\
\hline Riverside & $1 *$ & $475 / 2767$ & --- & --- & --- \\
\hline $\begin{array}{l}\text { Monterey } \\
\text { (Estrada) }\end{array}$ & --- & --- & $10 / 460$ & $10 / 460$ & --- \\
\hline $\begin{array}{l}\text { (Cooper- } \\
\text { Molera) }\end{array}$ & --- & -- & $2 / 118$ & -- & --- \\
\hline San Jose** & $\mathbf{x}$ & $\mathbf{x}$ & $\mathbf{x}$ & --- & --- \\
\hline $\begin{array}{l}\text { San Francisco } \\
\text { (Hoff Store) }\end{array}$ & -- & --- & --- & $\cdots$ & --- \\
\hline (China Camp) & --- & $262 / 1109$ & $7 / 1109$ & -- & $--\cdot$ \\
\hline Sacramento & -- & -- & --- & --- & -- \\
\hline Walnut Grove & -- & $1 / 1106$ & -.- & -- & --- \\
\hline Woodland & --- & $9 / 240$ & --- & -- & --- \\
\hline Marysville & --- & $1061 / 5253$ & --- & $132 / 5253$ & -- \\
\hline Igo-Piety Hill & --- & $6 / 53$ & --- & -- & --- \\
\hline $\begin{array}{l}\text { Dutch Gulch } \\
\text { Lake }\end{array}$ & -- & $139 / 3183$ & -- & --- & --- \\
\hline Weaverville*** & --- & $25 / ?$ & --- & --- & --- \\
\hline $\begin{array}{l}\text { Arizona } \\
\text { Tucson*** }\end{array}$ & --- & $12 / ?$ & -- & --- & $\cdots$ \\
\hline $\begin{array}{l}\text { Nevada } \\
\text { Lovelock }\end{array}$ & -- & $21 / 2907$ & -- & --- & -- \\
\hline
\end{tabular}

* Only one vessel of this type can be identified with certainty (Mueller 1987:281). ** Site report not written; figures not available.

*** Total ceramic assemblage unknown.

Note: Figures to left of slash are the number of specimens of a given type; figures to the right represent the total ceramic assemblage of the site. 


\begin{tabular}{|c|c|c|c|c|c|}
\hline Site & $\begin{array}{c}\text { Rocks \& } \\
\text { Orchid }\end{array}$ & Bamboo & $\begin{array}{c}\text { Peach \& } \\
\text { Fungus }\end{array}$ & $\mathbf{F u}$ & Snail \\
\hline$\underset{\text { Ventura }}{\text { California }}$ & --- & 7.8 & -- & --- & $?$ \\
\hline Riverside & 0.04 & 17.2 & --- & -- & $\cdots$ \\
\hline $\begin{array}{l}\text { Monterey } \\
\text { (Estrada) }\end{array}$ & -- & --- & 2.2 & 2.2 & -- \\
\hline $\begin{array}{l}\text { (Cooper- } \\
\text { Molera) }\end{array}$ & -- & --- & 1.7 & --- & --- \\
\hline San Jose* & $?$ & $?$ & $?$ & -- & -- \\
\hline $\begin{array}{l}\text { San Francisco } \\
\text { (Hoff Store) }\end{array}$ & --- & -- & --- & --- & --- \\
\hline (China Camp) & --- & 23.6 & 0.6 & $\ldots$ & $\ldots$ \\
\hline Sacramento & -- & --- & --- & --- & --- \\
\hline Walnut Grove & --- & 0.09 & --- & -- & --- \\
\hline Woodland & --- & 3.8 & -- & $\cdots$ & -- \\
\hline Marysville & -- & 20.2 & --- & 2.5 & --- \\
\hline Igo-Piety Hill & -- & 11.3 & -- & -- & $-\cdots$ \\
\hline $\begin{array}{l}\text { Dutch Gulch } \\
\text { Lake }\end{array}$ & $-\cdots$ & 4.4 & --. & -- & $\ldots$ \\
\hline $\begin{array}{l}\text { Weaverville** } \\
\text { Arizona } \\
\text { Tucson** }\end{array}$ & --- & $?$ & --- & $\ldots$ & $\ldots$ \\
\hline $\begin{array}{l}\text { Nevada } \\
\text { Lovelock }\end{array}$ & -- & 0.7 & $\ldots$ & -.. & -.. \\
\hline
\end{tabular}

* San Jose site report not written; figures not available.

** Total ceramic assemblage unknown. 


\section{FIGURES}

116 

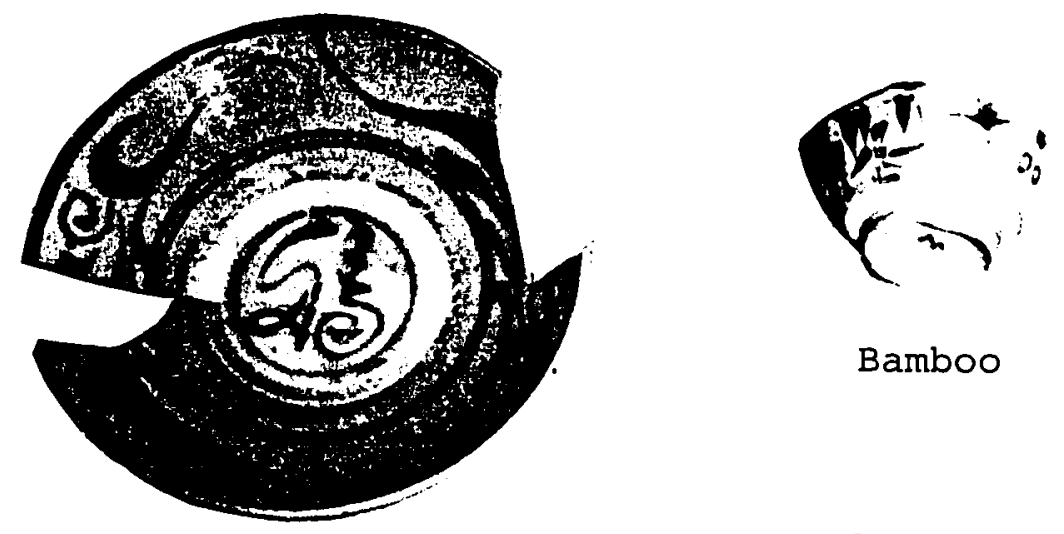

Fu
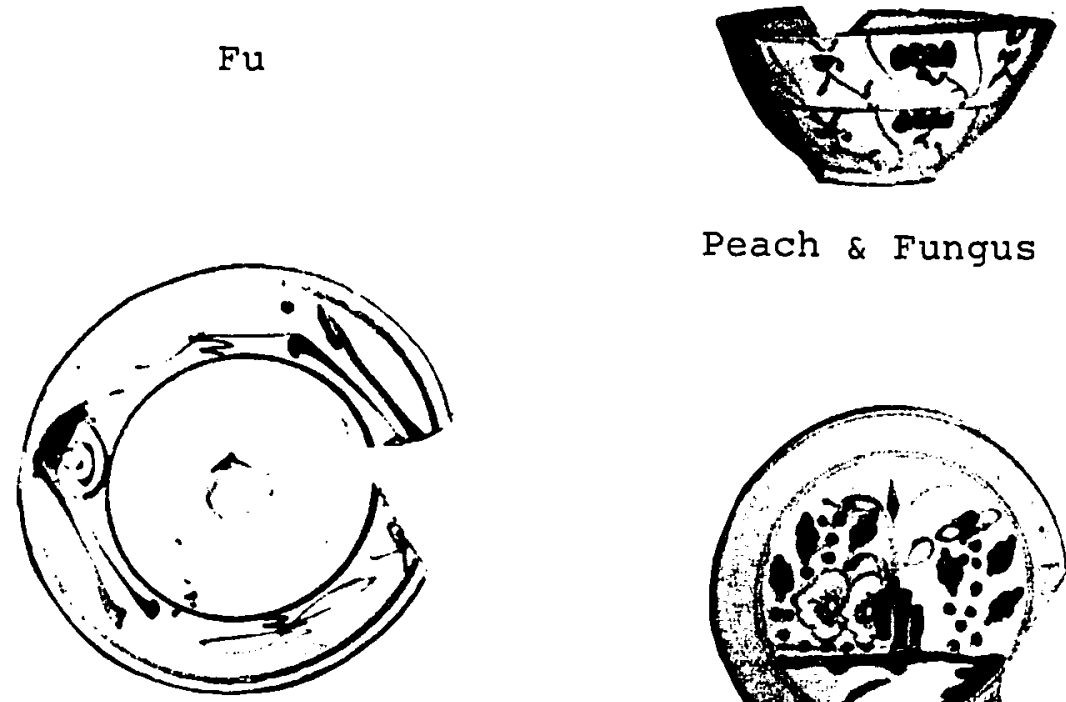

Peach \& Fungus

Snail

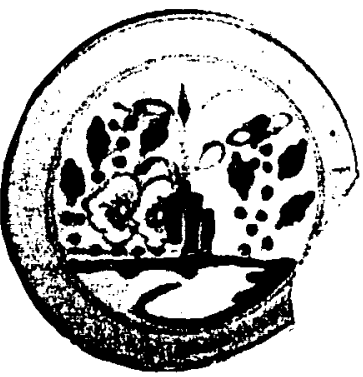

Rocks \& Orchid

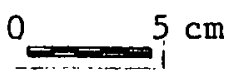

Figure 1. Five major types of Chinese blue-and-white export ceramics from the Frolic. 


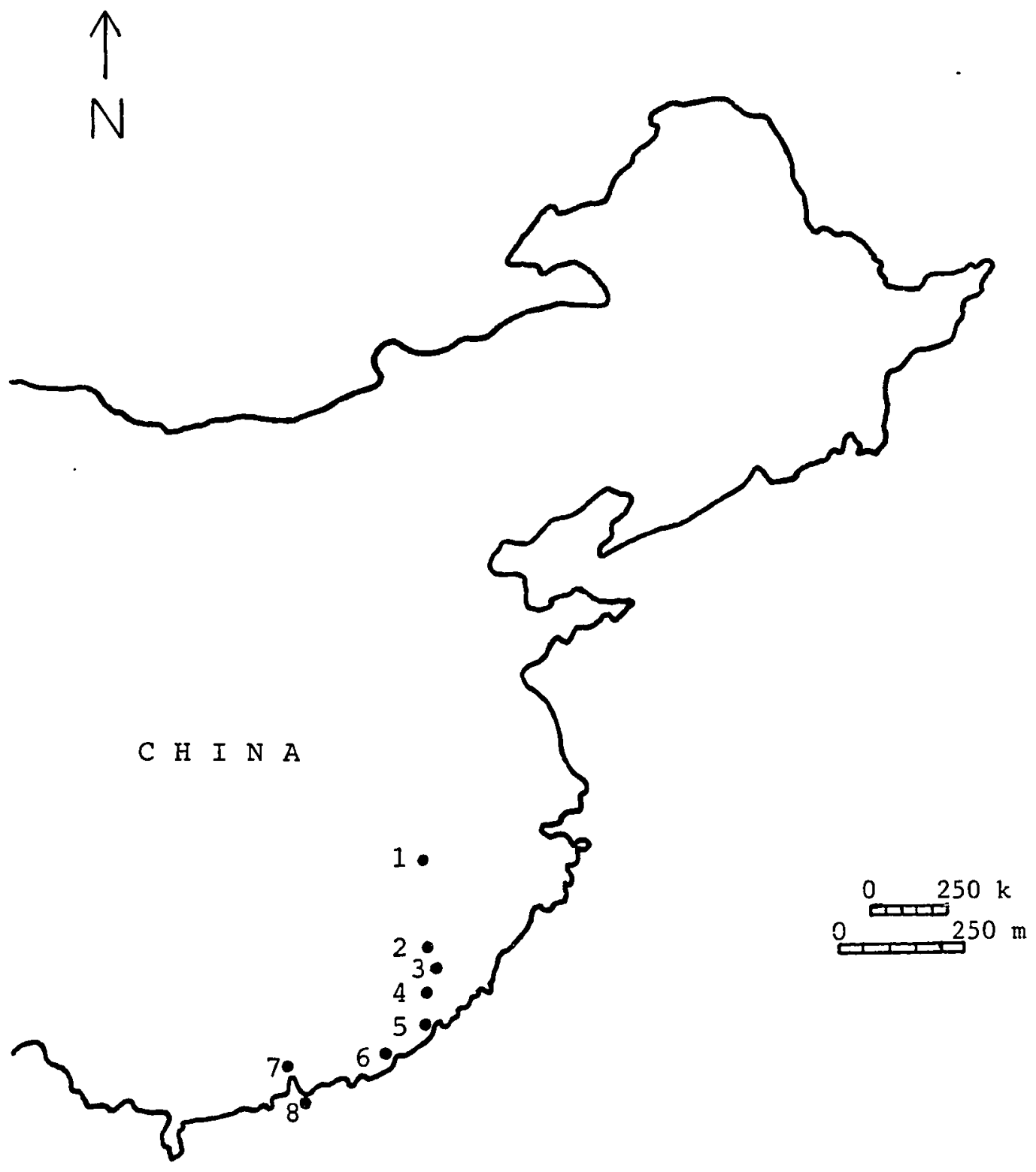

Figure 2. Chinese kiln sites and export centers.

Kiln sites:

1. Jingdezhen

2. Dehua

3. Yongchun

4. Anxi
Export centers:

5. Xiamen (Amoy)

6. Shantou (Swatow)

7. Guangzhou (Canton)

8. Hong Kong 

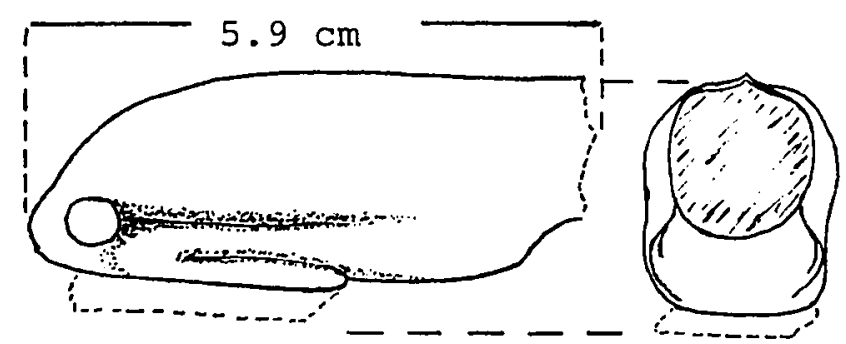

a

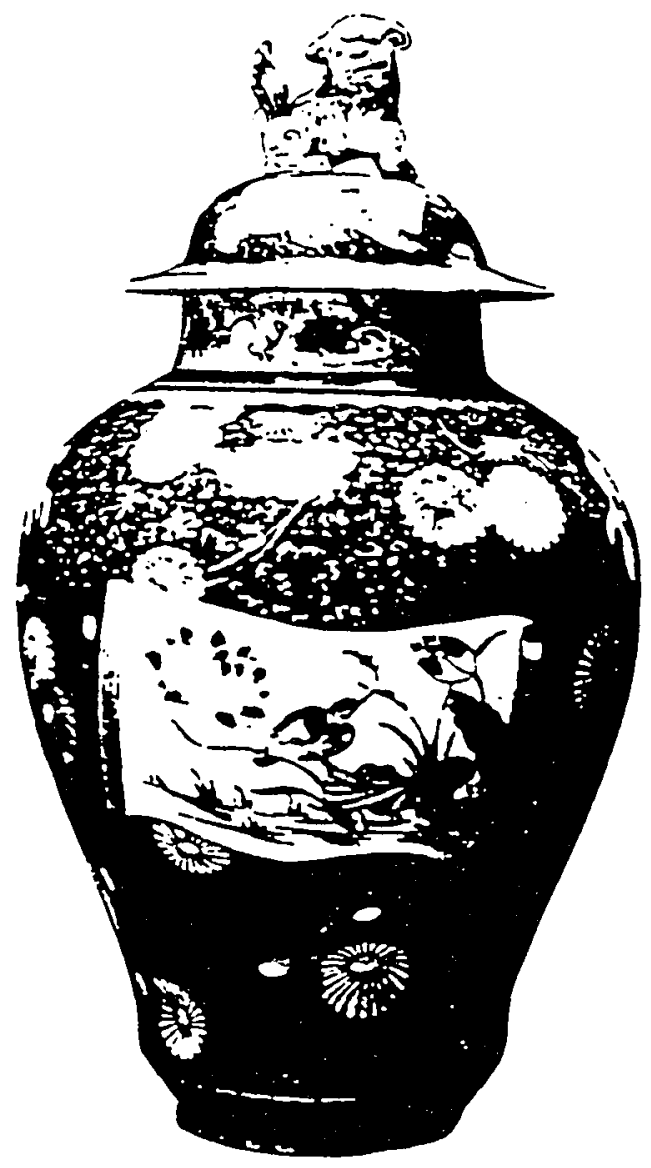

b

Figure 3. Knop-handle (a) and ornamental lion-dog finial (b). Illustration from Mudge (1986:24). 

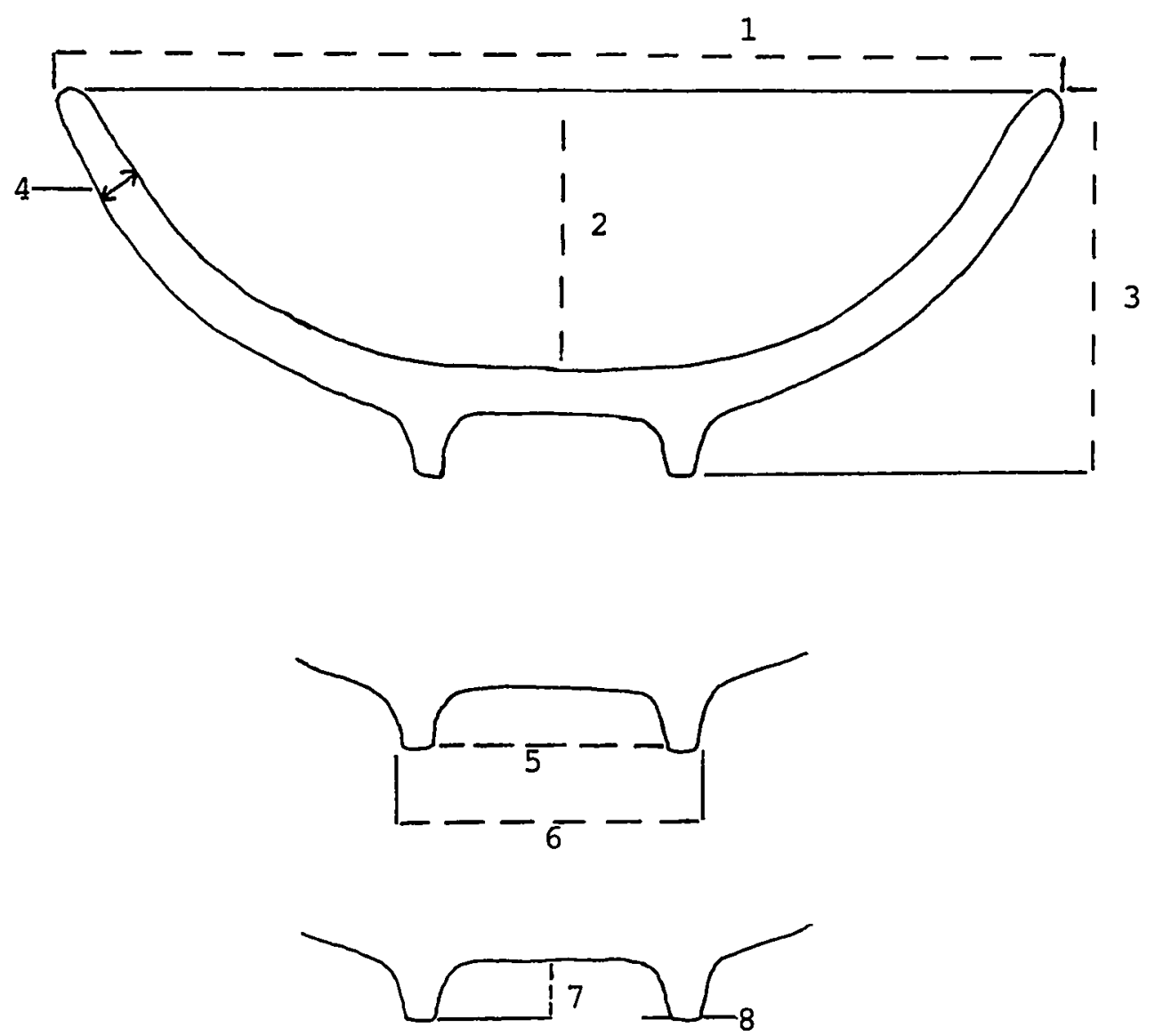

Figure 4. Location of vessel measurements.

1. Rim diameter

2. Inside height

3. Outside height

4. Wall thickness
5. Inside footring diameter

6. Outside footring diameter

7. Inside footring height

8. Width of footring at edge 


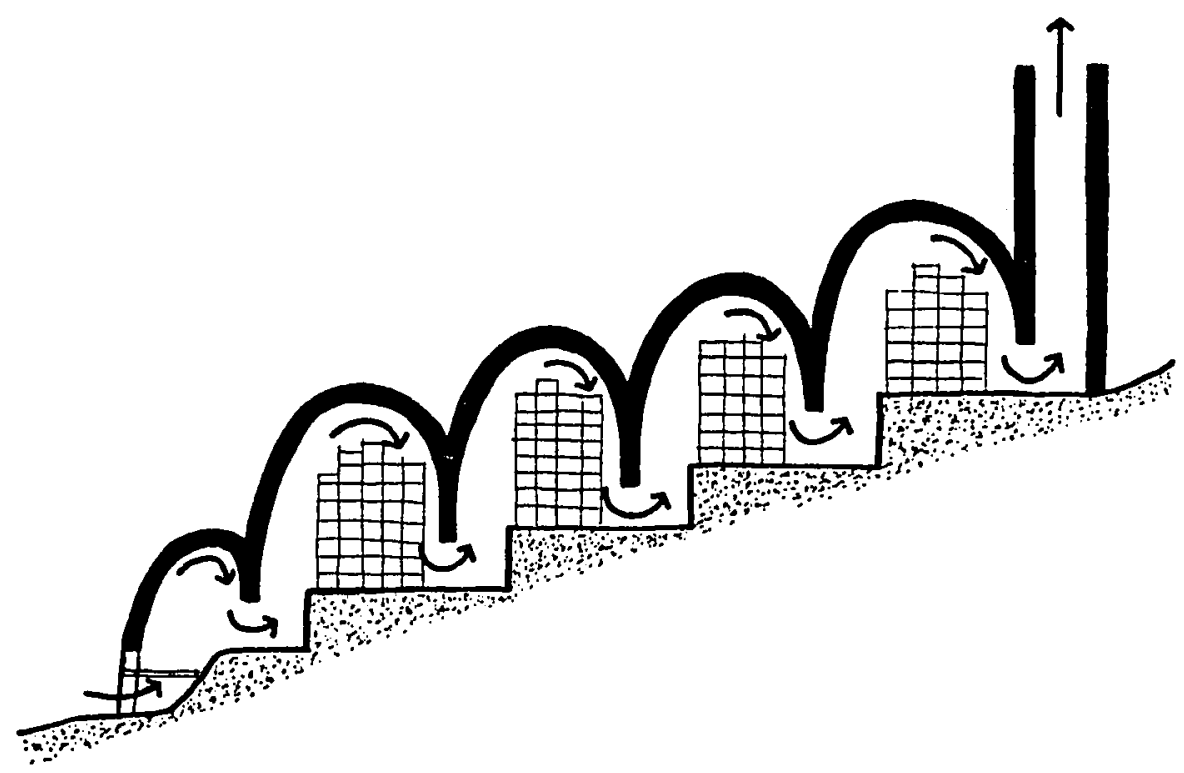

a) climbing kiln

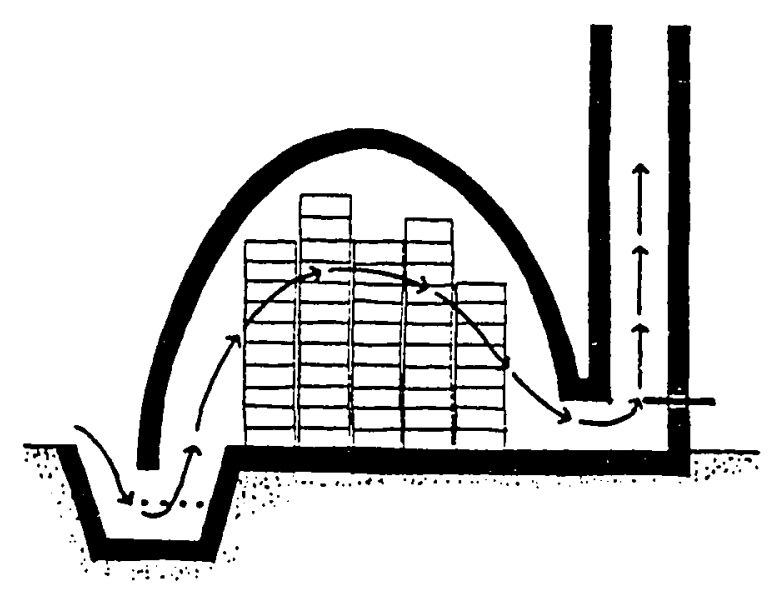

b) Bee-hive kiln

Figure 5. Kiln designs. Illustrations from Nelson (1966:229). 

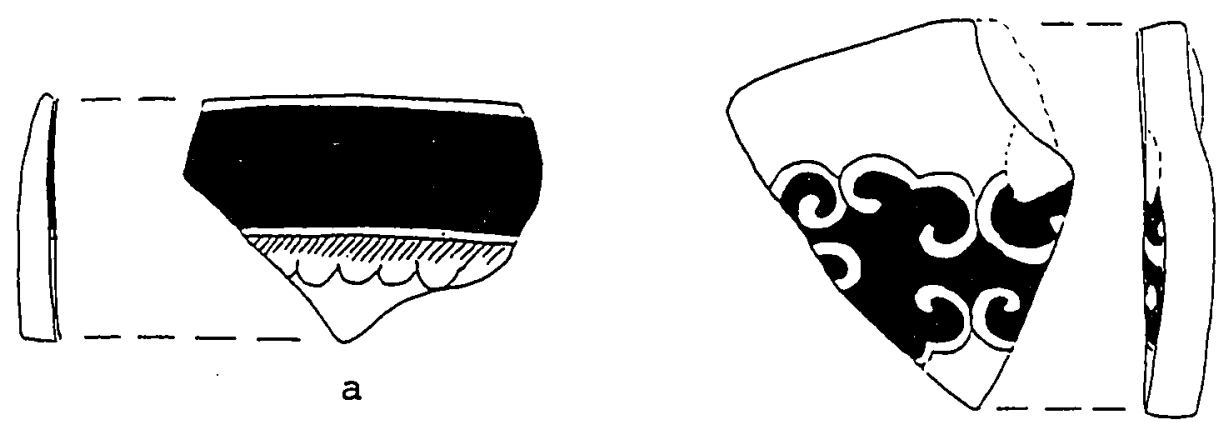

$\mathrm{b}$
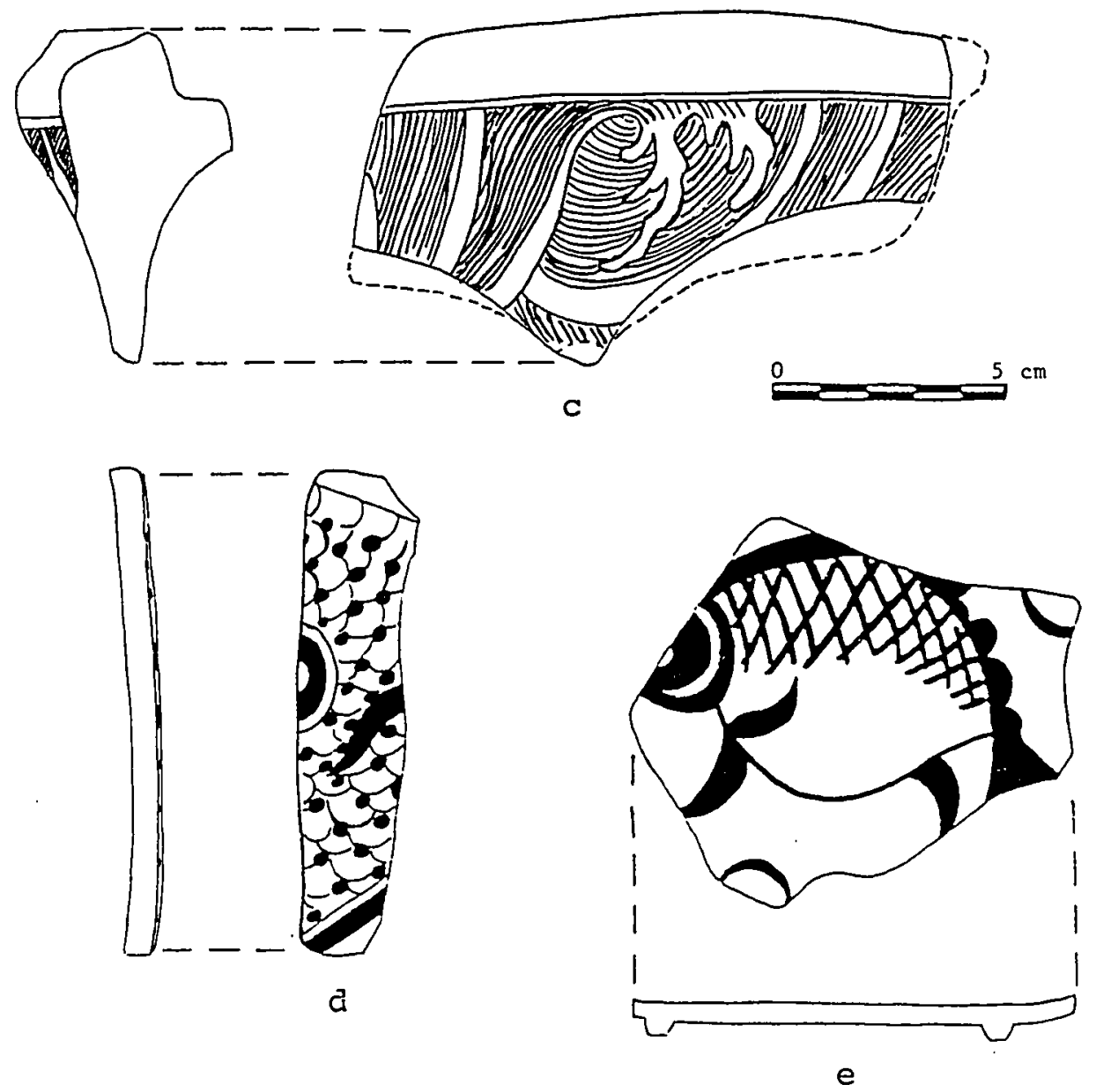

Figure 6. Miscellaneous blue-and-white sherds, depicting: a) rain and clouds, b) cloud, c) waves, d) carp, and e) catfish. 


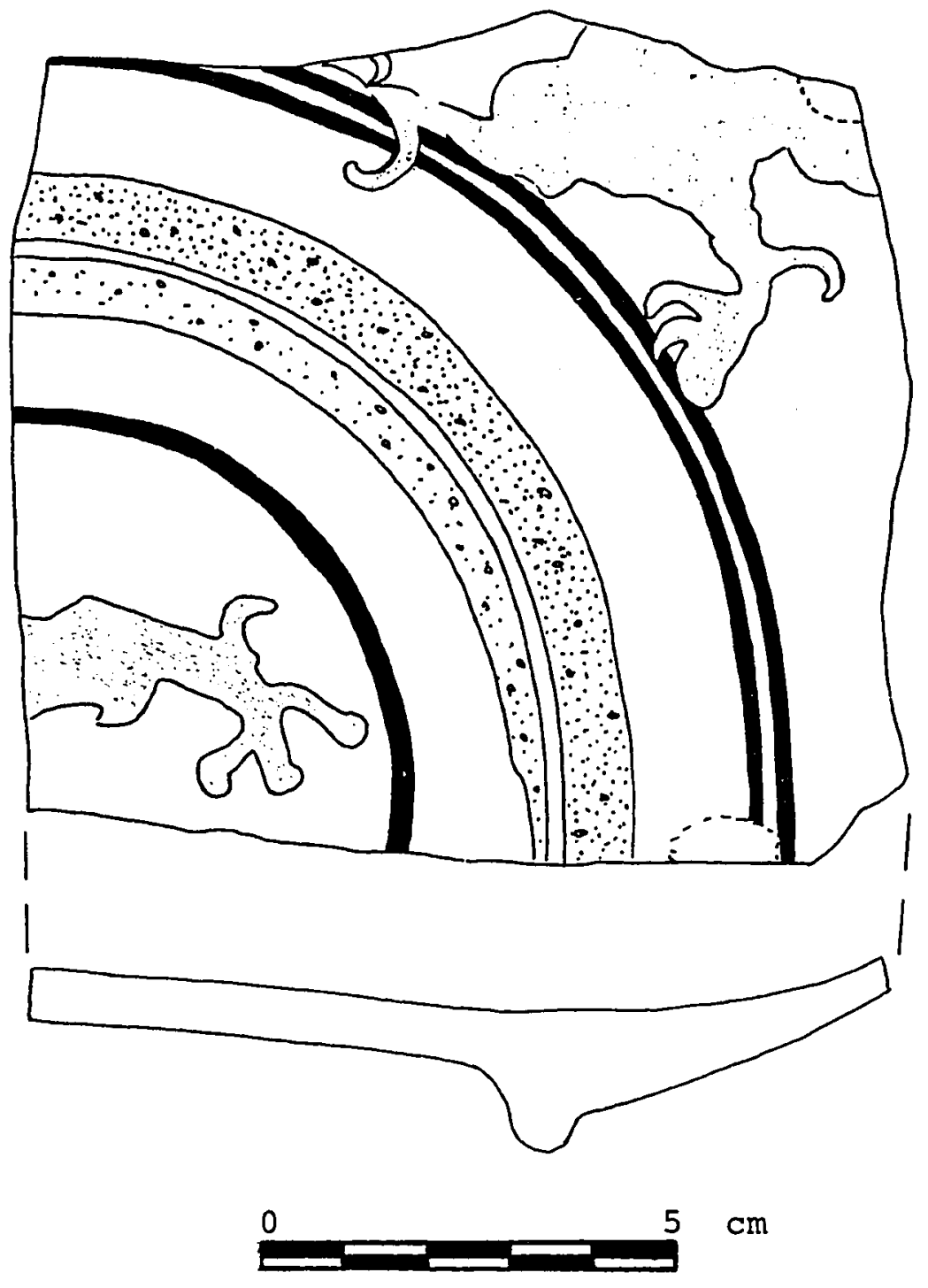

Figure 7. Miscellaneous blue-and-white sherd with dragon feet. 


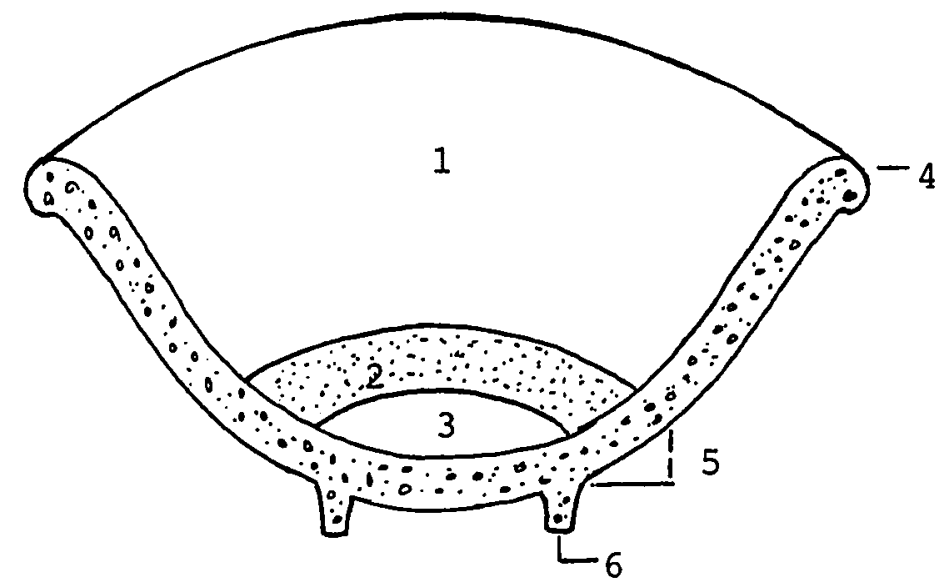
1. Cavetto
3. Well
5. Shoulder
2. Bisque band
4. Rim
6. Footring

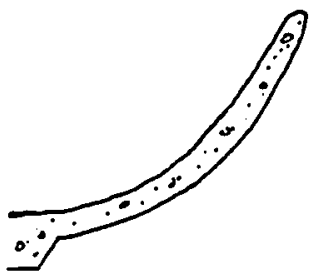

Rounded

Rim
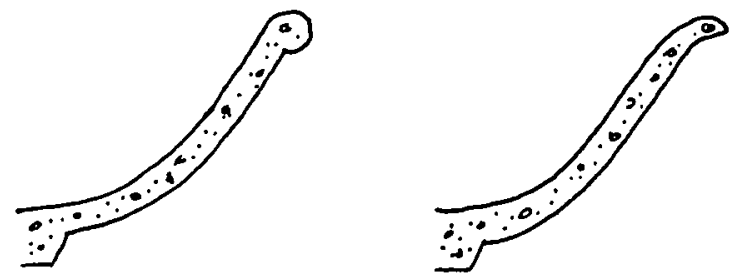

Rolled

Everted

Rim

Rim

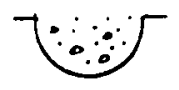

Rounded Footring

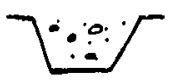

Footring SNAIL Variety

$A, B \& C$

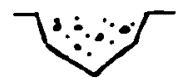

Footring SNAIL Variety D

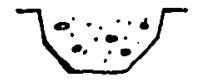

Footring SNAII Variety

Figure 8. Cross-sections of vessel components, rim designs, and footring forms. 

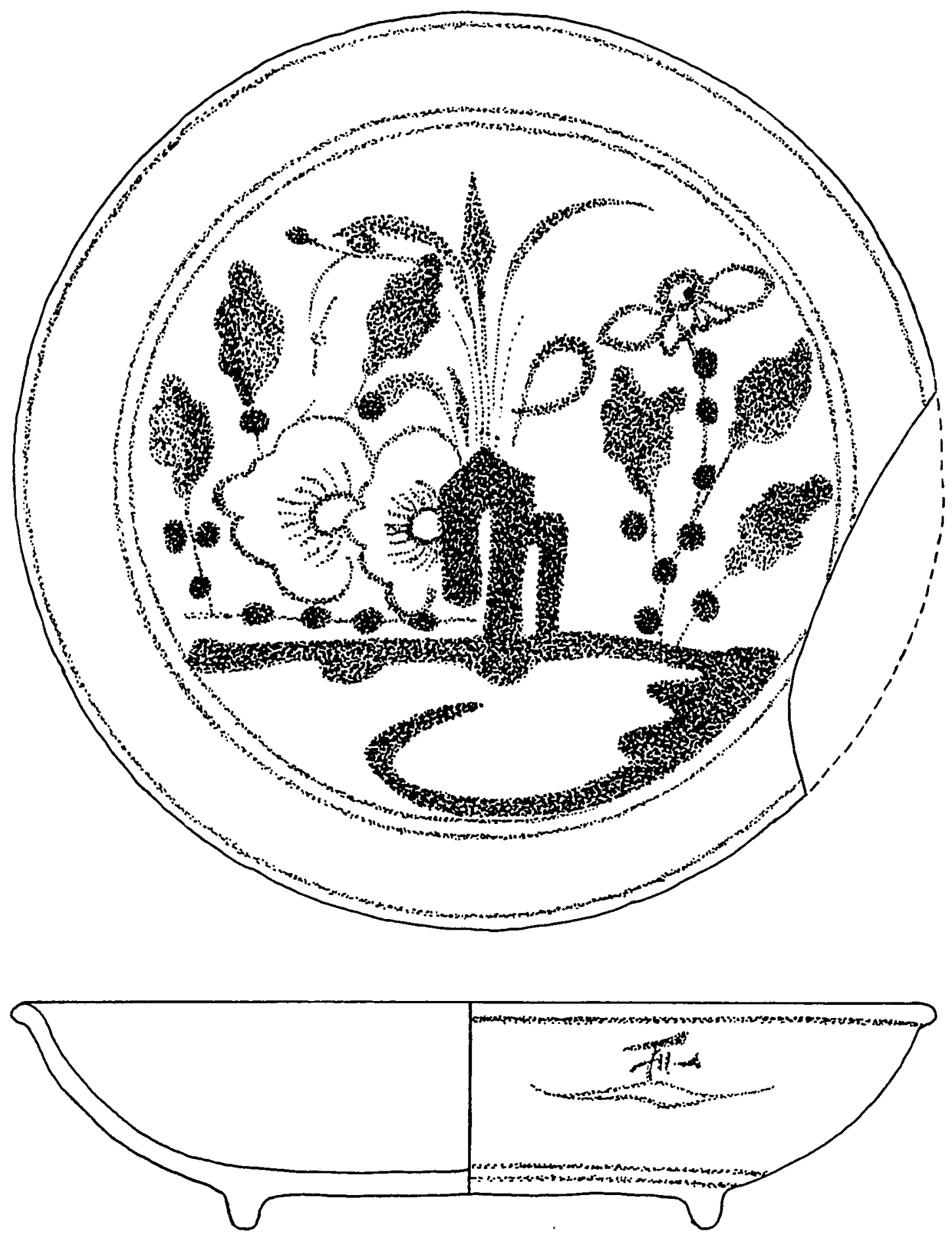

Figure 9. ROCKS \& ORCHID Type (dia. 14.8-15.2 cm) 


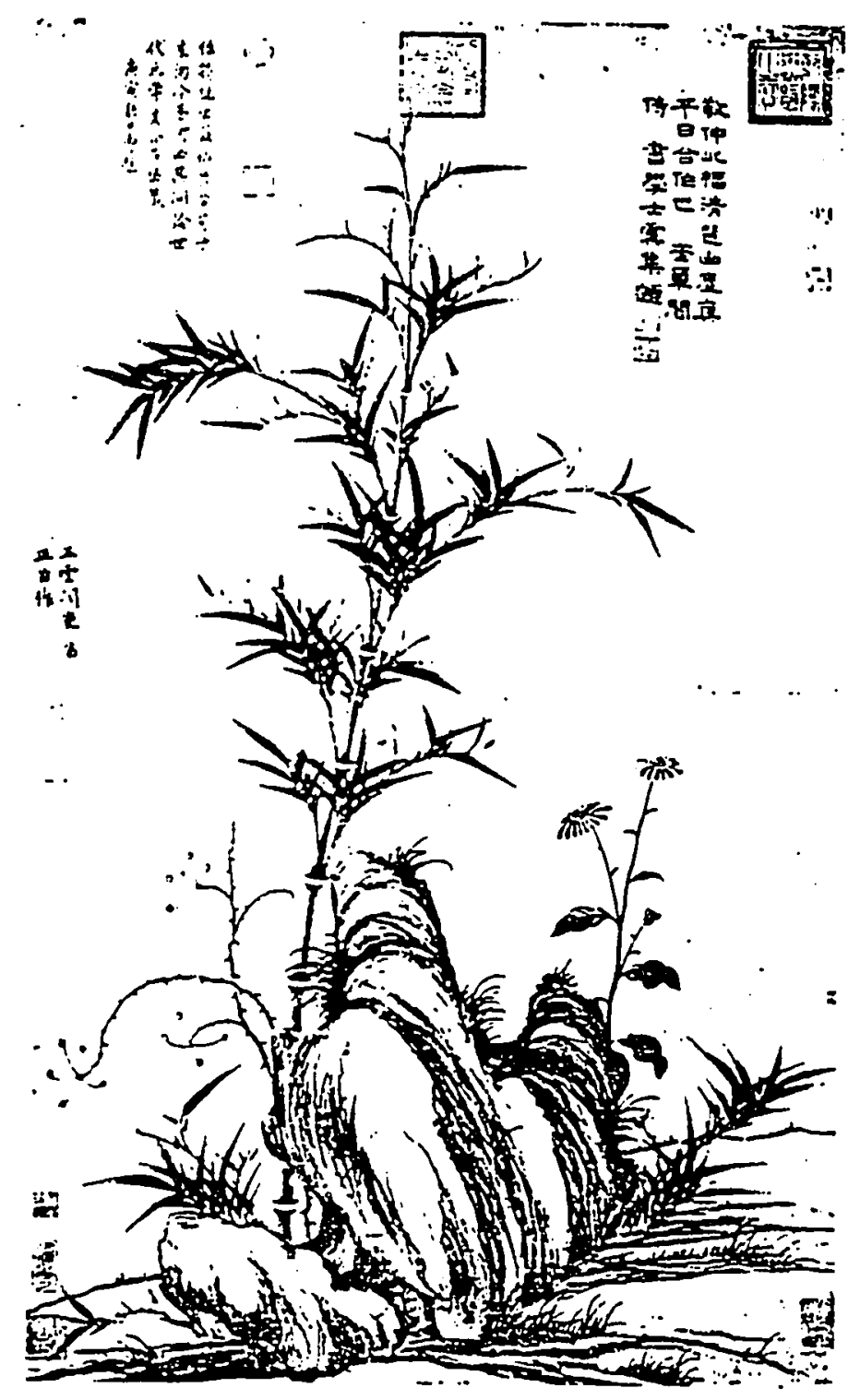

Figure 10. Rock and bamboo design from Yuan dynasty scroll painting. Illustration from Maust (1973:32). 

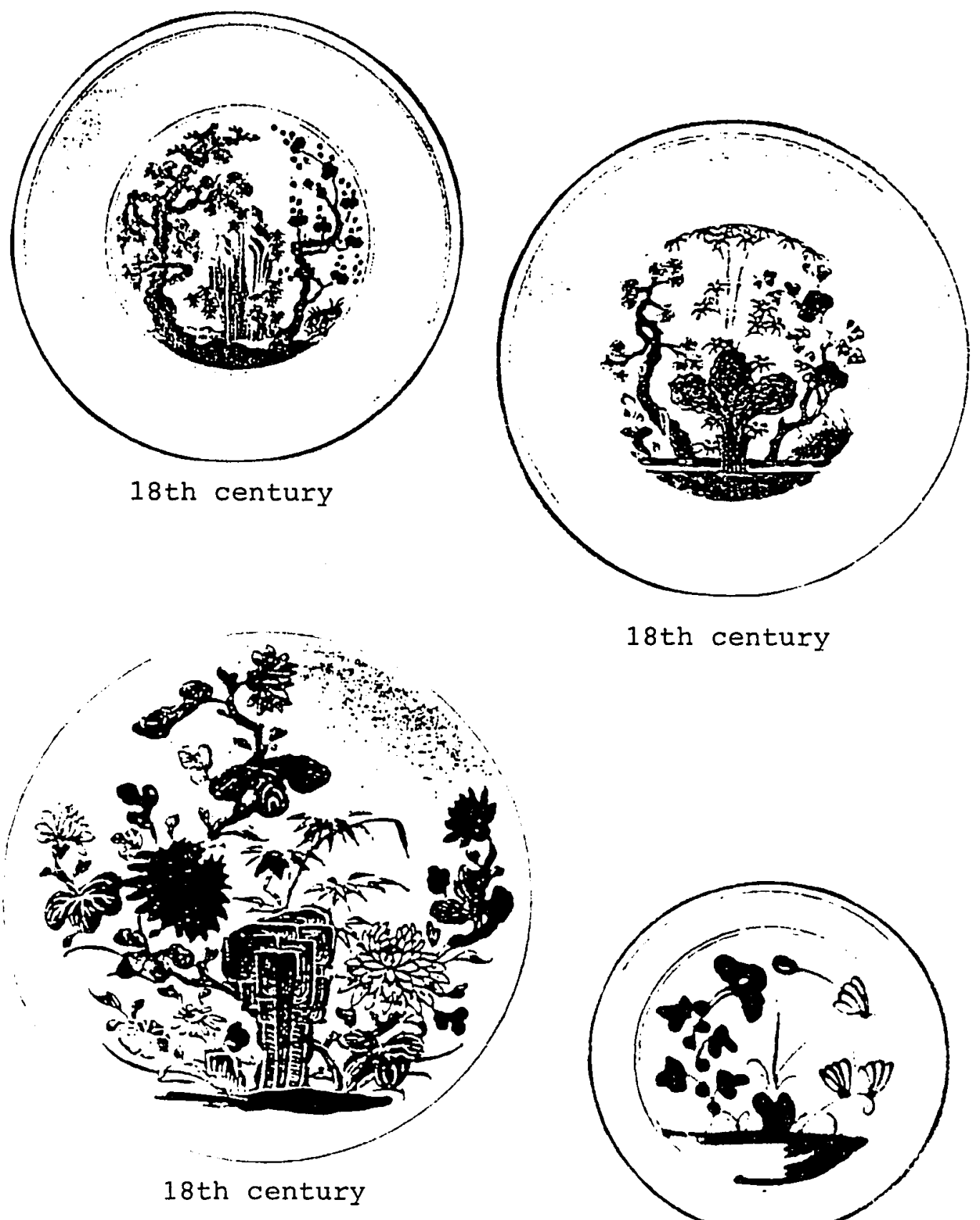

18th century

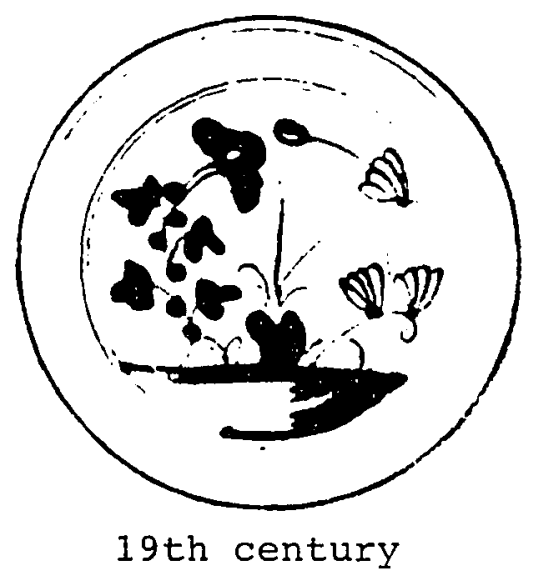

Figure 11. Traditional representation of "Three Friends" motif using pine, prunus, rock, chrysanthemum and bamboo. 


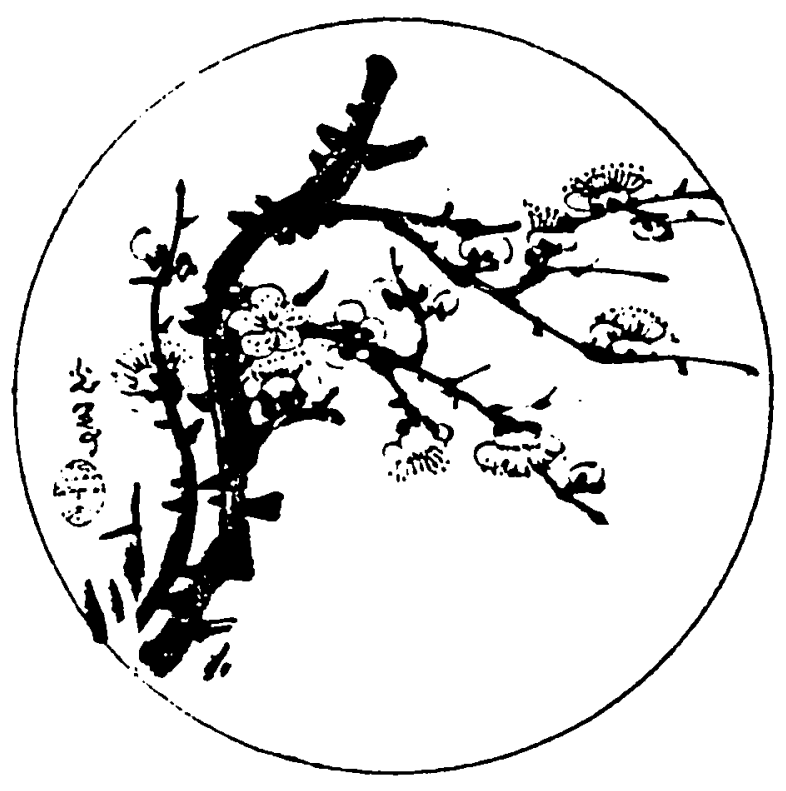

a

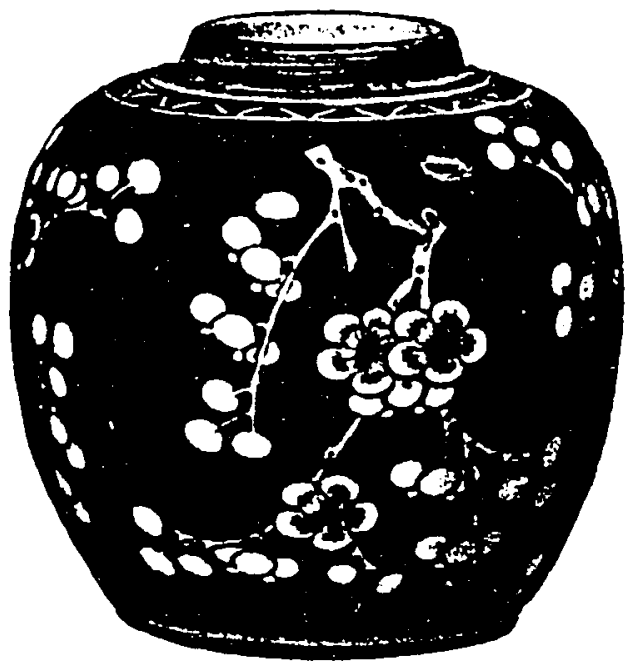

b

Figure 12. Traditional representations of plum blossom. Illustrations from leong (1974:55) and Yeo and Martin (1978:244). 


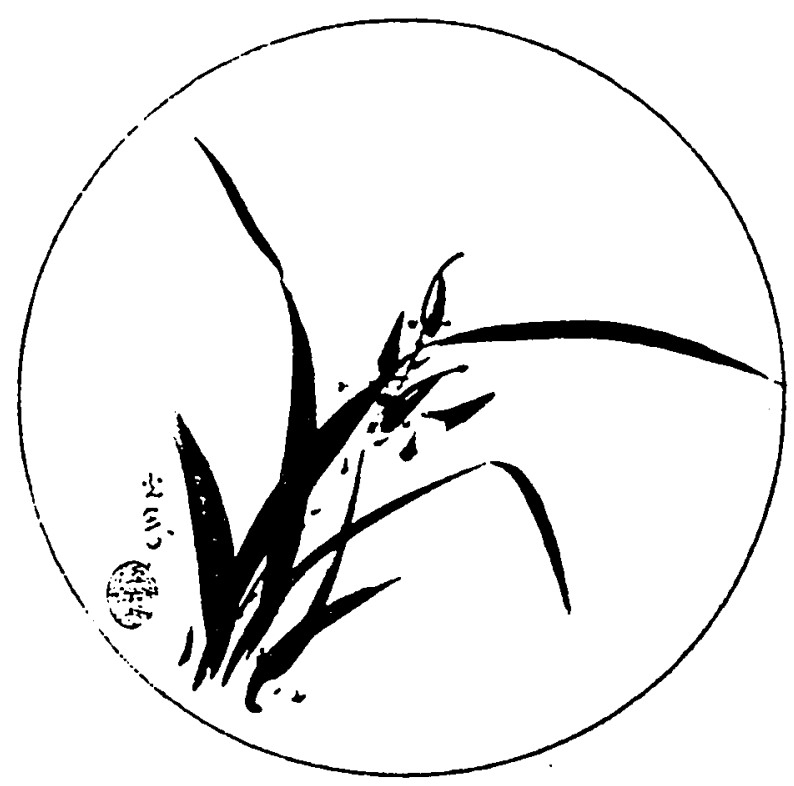

a) Orchid

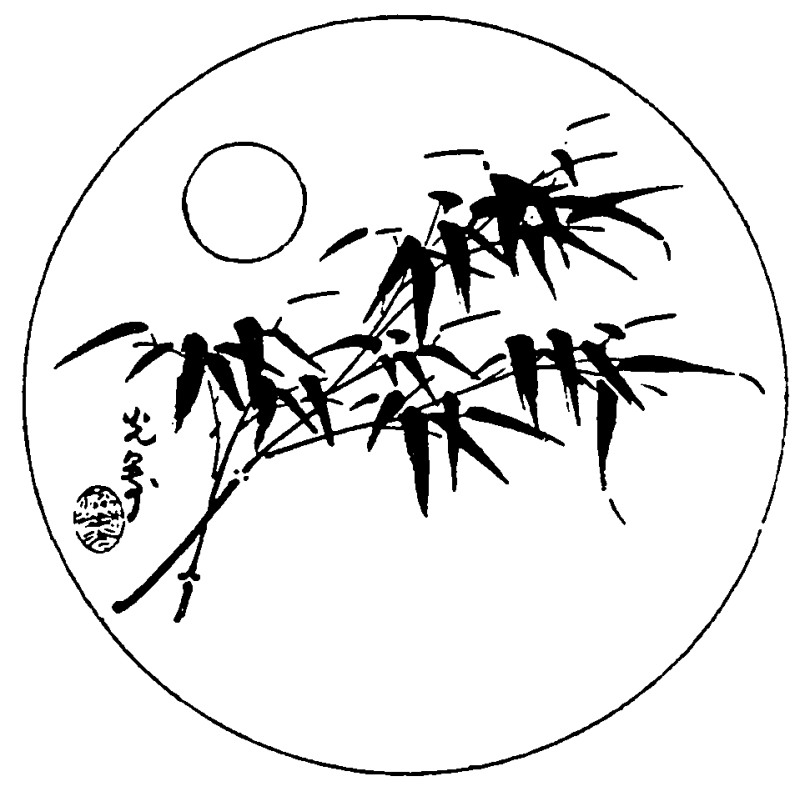

b) Bamboo

Figure 13. Traditional representation of orchid and bamboo. Illustrations from Leong (1974:55). 

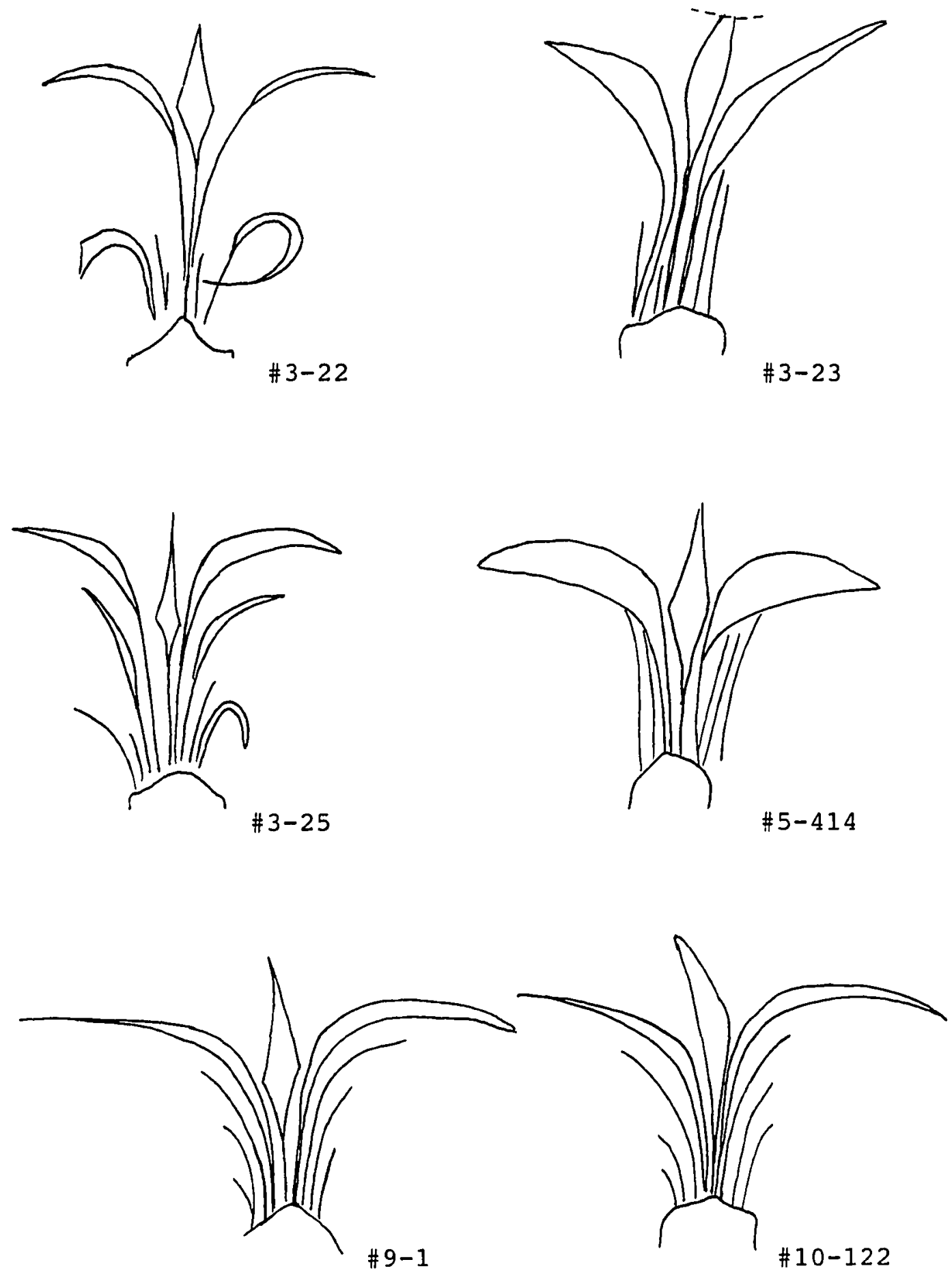

Figure 14. Variations of orchid motif on ROCKS \& ORCHID TYpe. 

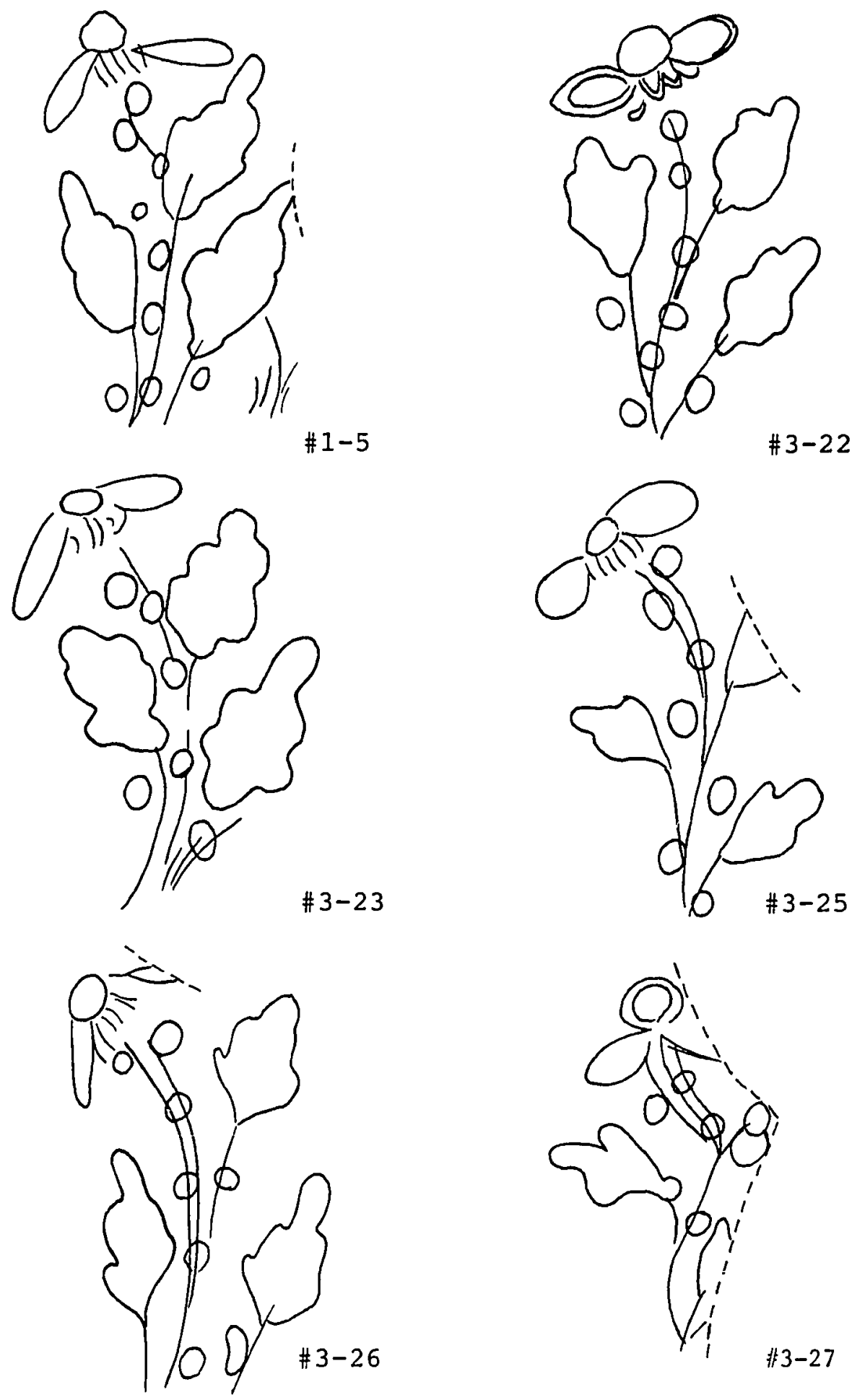

Figure 15. Variations of chrysanthemum motif on ROCKS \& ORCHID TYpe. 

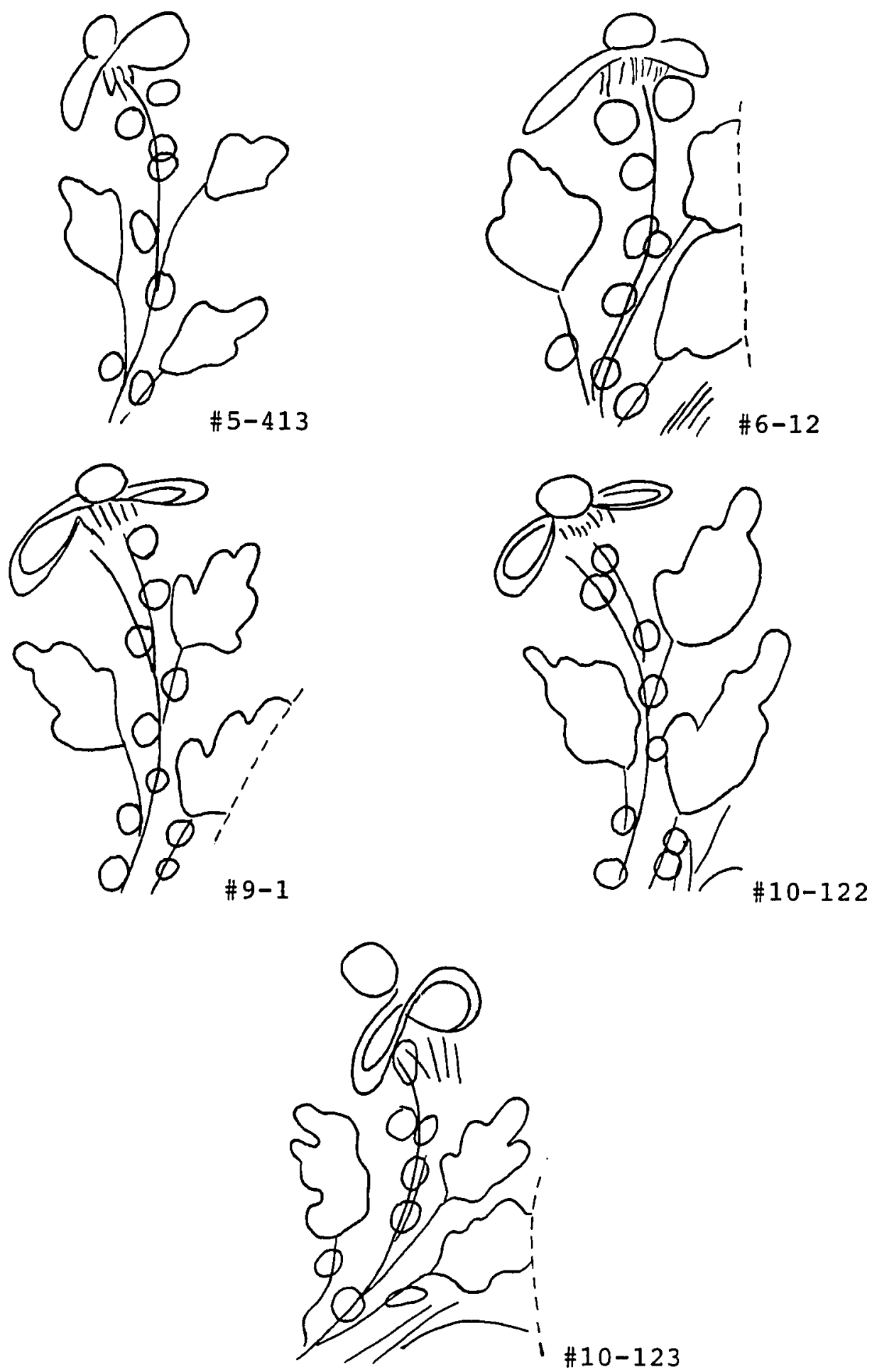

Figure 15. (cont.). Variations of chrysanthemum motif on ROCKS \& ORCHID Type. 

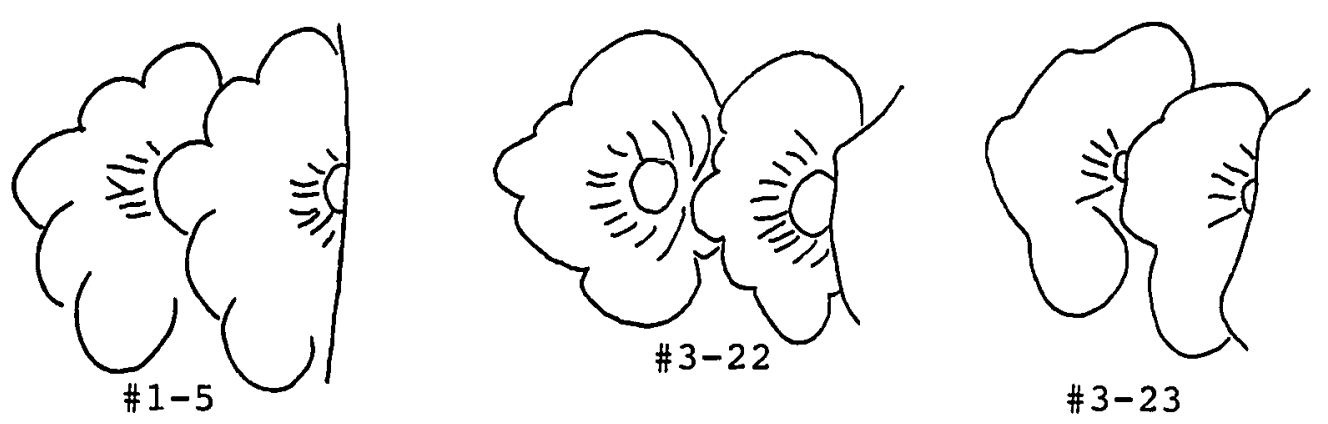

\#3-23
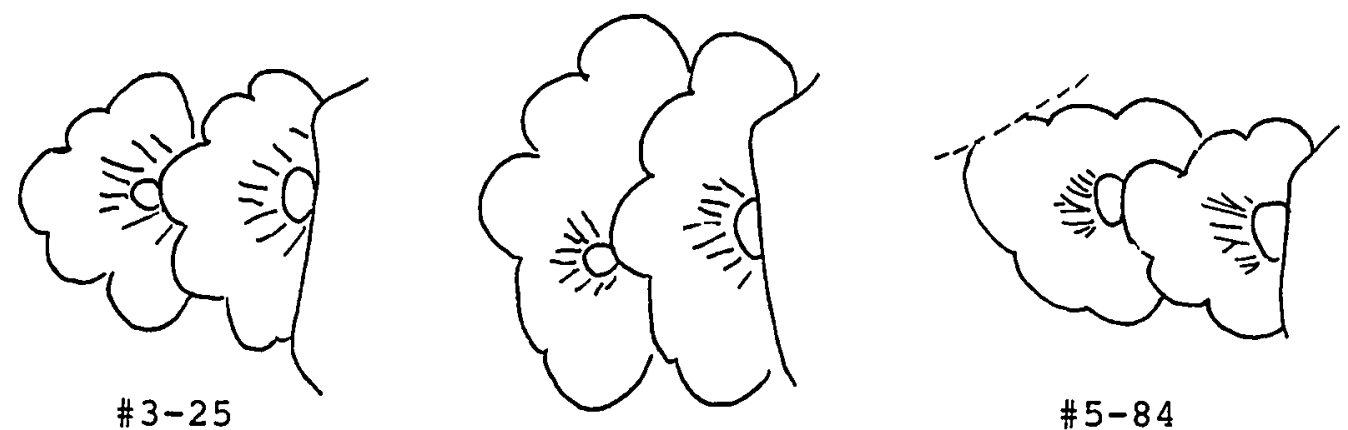

\# 3-25

\#3-26

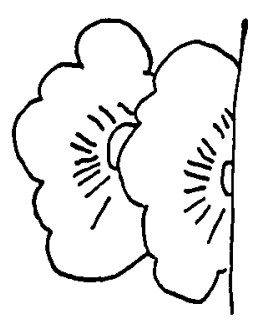

$$
\text { \# 5-277 }
$$
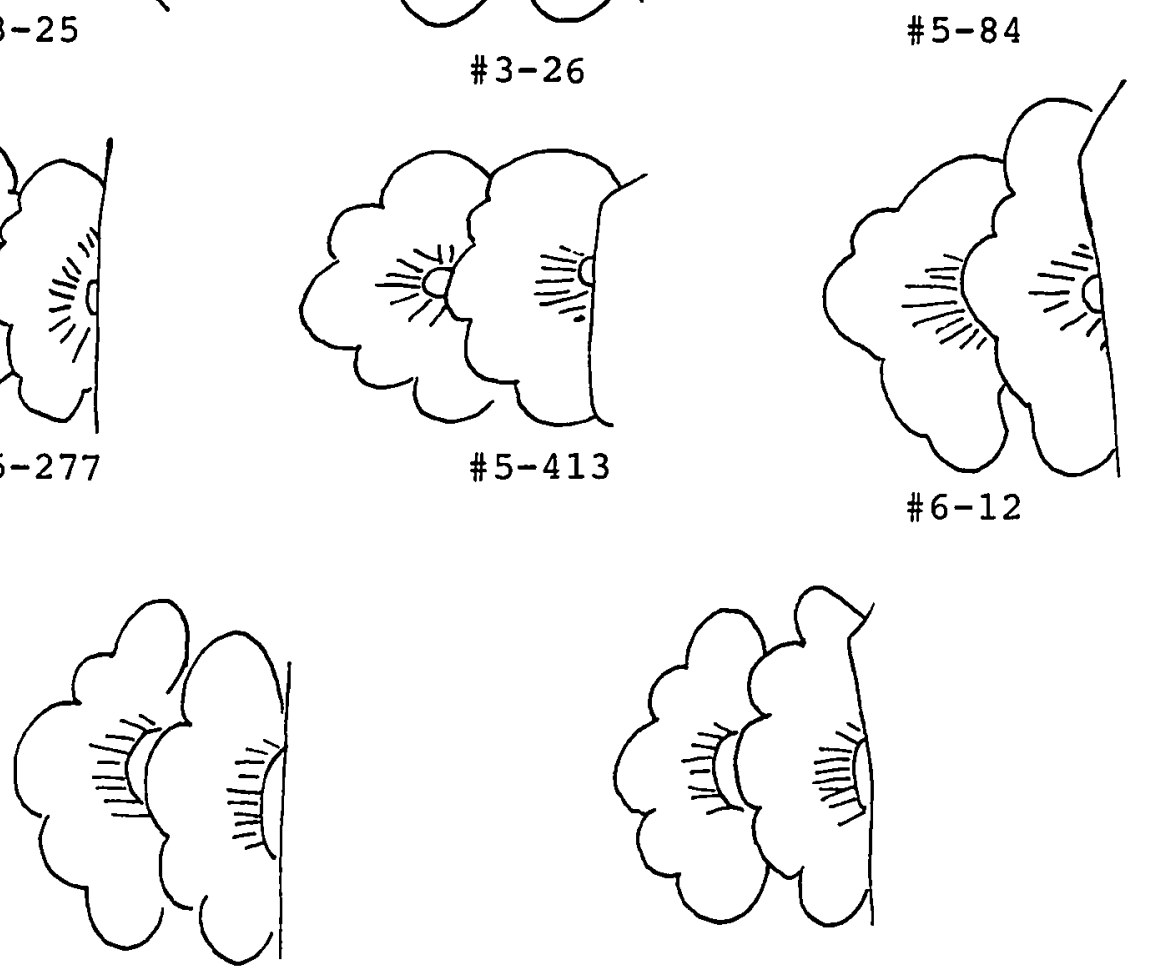

$$
\# \text { 9-1 }
$$

\#10-122

Figure 16. Variations of plum or prunus motif on ROCKS \& ORCHID Type. 

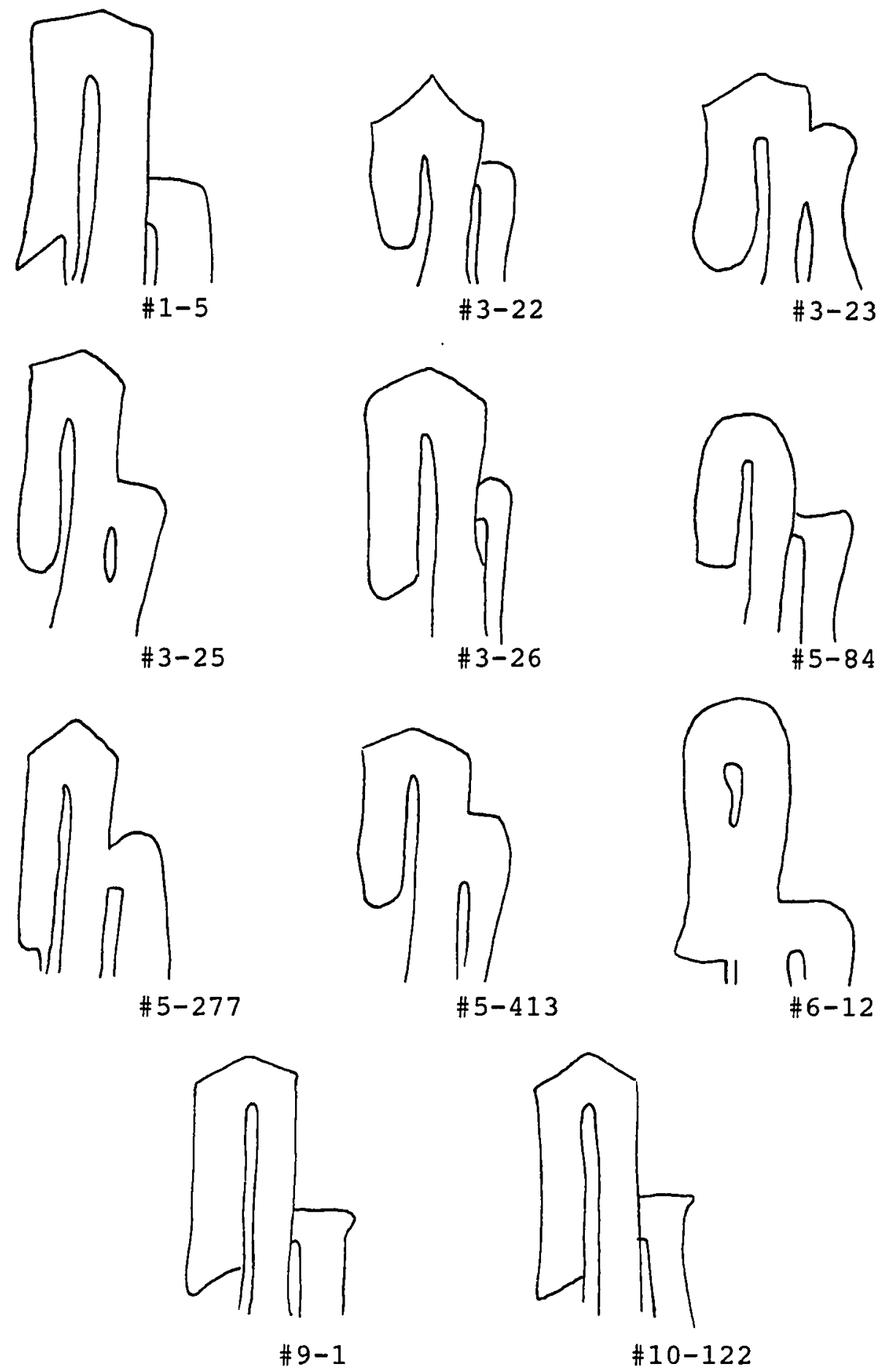

Figure 17. Variations of rock motif on ROCKS \& ORCHID Type. 
135
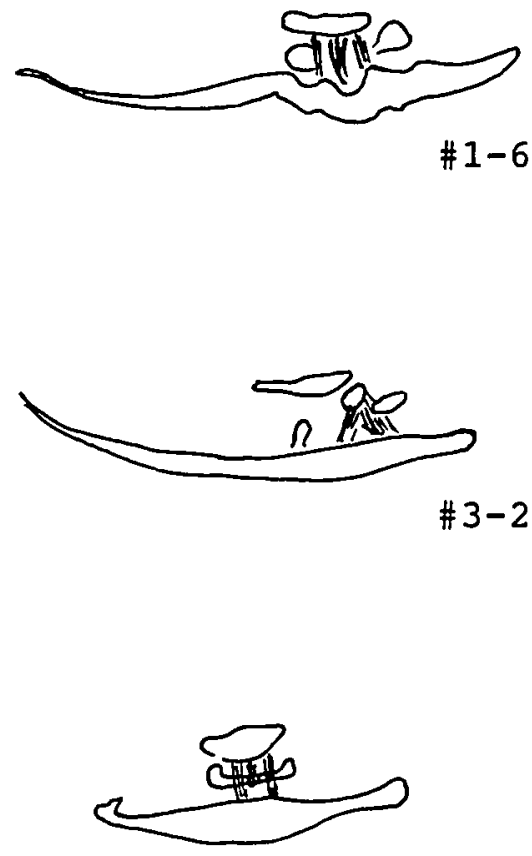

\#5-416

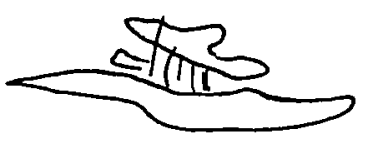

\#6-12

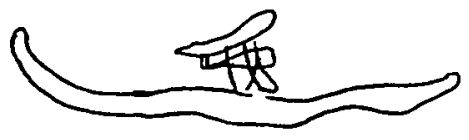

\# 8-12
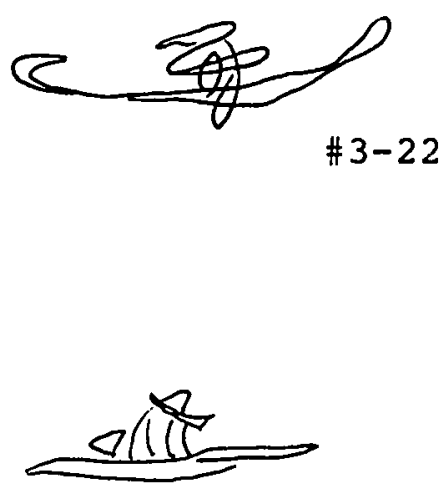

\# 5-82

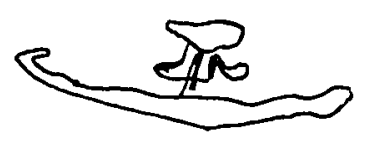

\#5-418

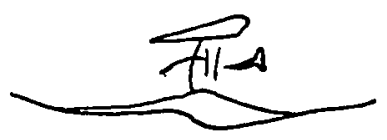

\# 8-11

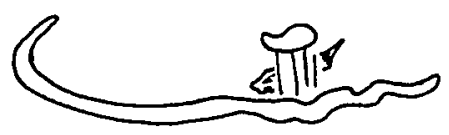

$\# 10-122$

Figure 18. Variations of design motif on reverse of ROCKS \& ORCHID type. 


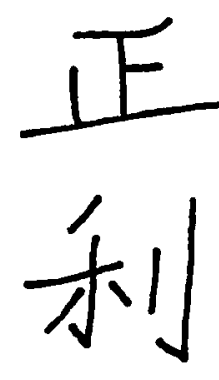

$\# 1-5$

$9-1$

$10-122$

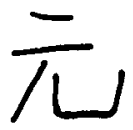

411
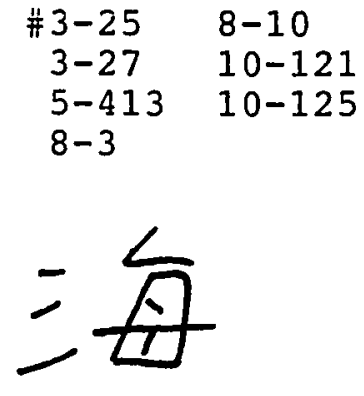

$\frac{1}{2}$

$$
\begin{aligned}
& \# 3-31 \\
& 3-116
\end{aligned}
$$

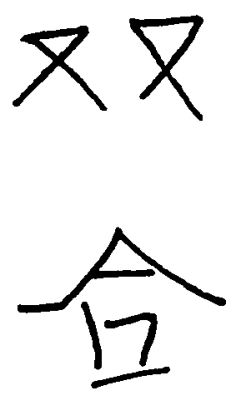

$$
\# 3-22
$$$$
8-13
$$

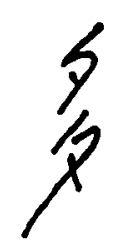

$\frac{1}{11}$

$\# 3-23$<smiles>[Y]</smiles>

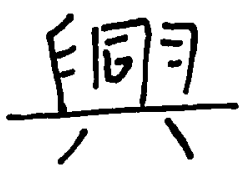

$\frac{1}{\pi} 1$

$$
\# 3-26
$$$$
8-8
$$

$$
\begin{array}{r}
\#-30 \\
6-12
\end{array}
$$

禾口

川臭

$$
\begin{array}{rl}
\# 5-272 & 8-4 \\
5-277 & 8-5 \\
5-278 & 10-123
\end{array}
$$

Figure 19. Chinese characters within footring of ROCKS \& ORCHID type (see Table 9 for translations). 

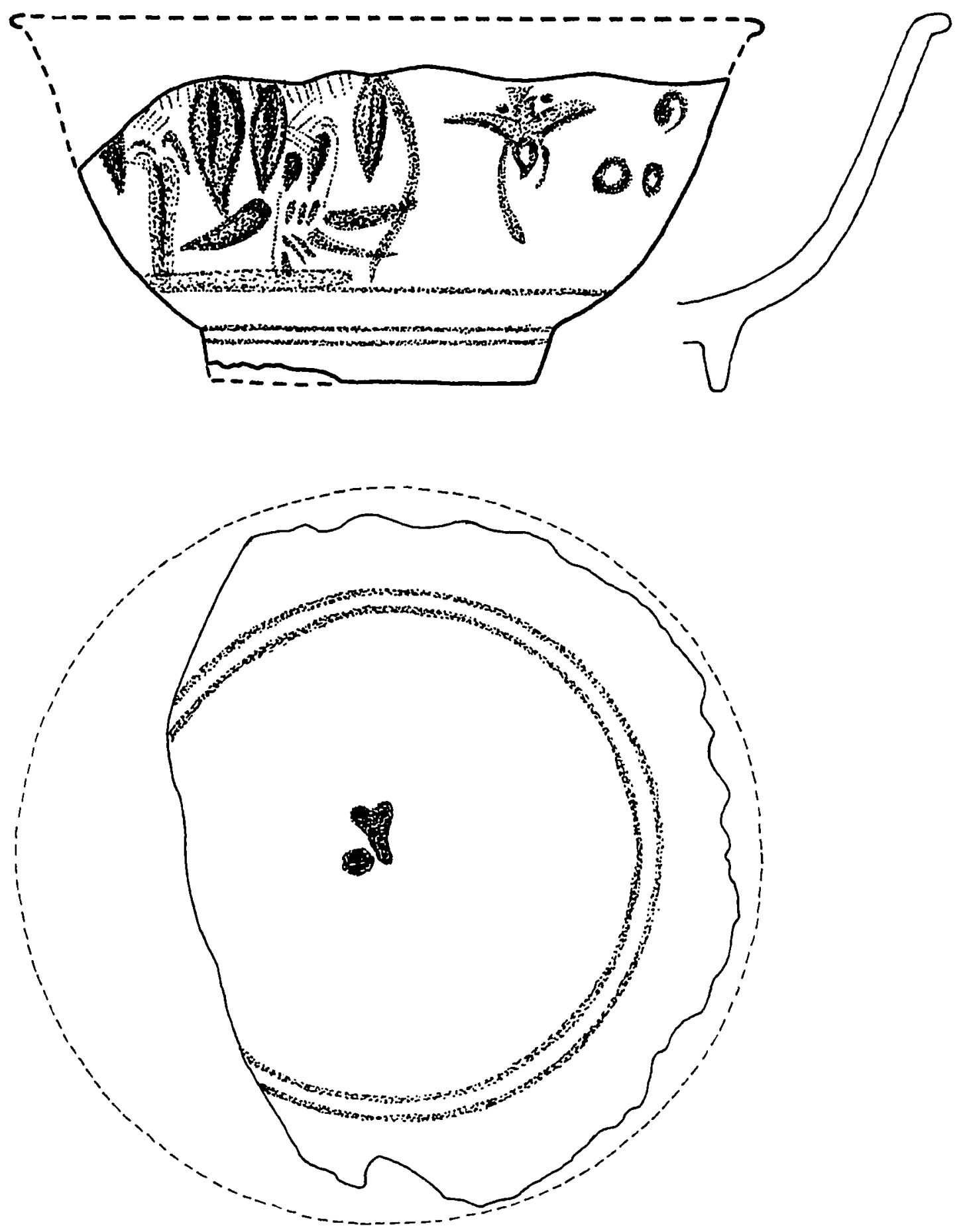

Figure 20. BAMBOO Type, including well and cavetto design (est. dia. $12.2 \mathrm{~cm}$ ). 

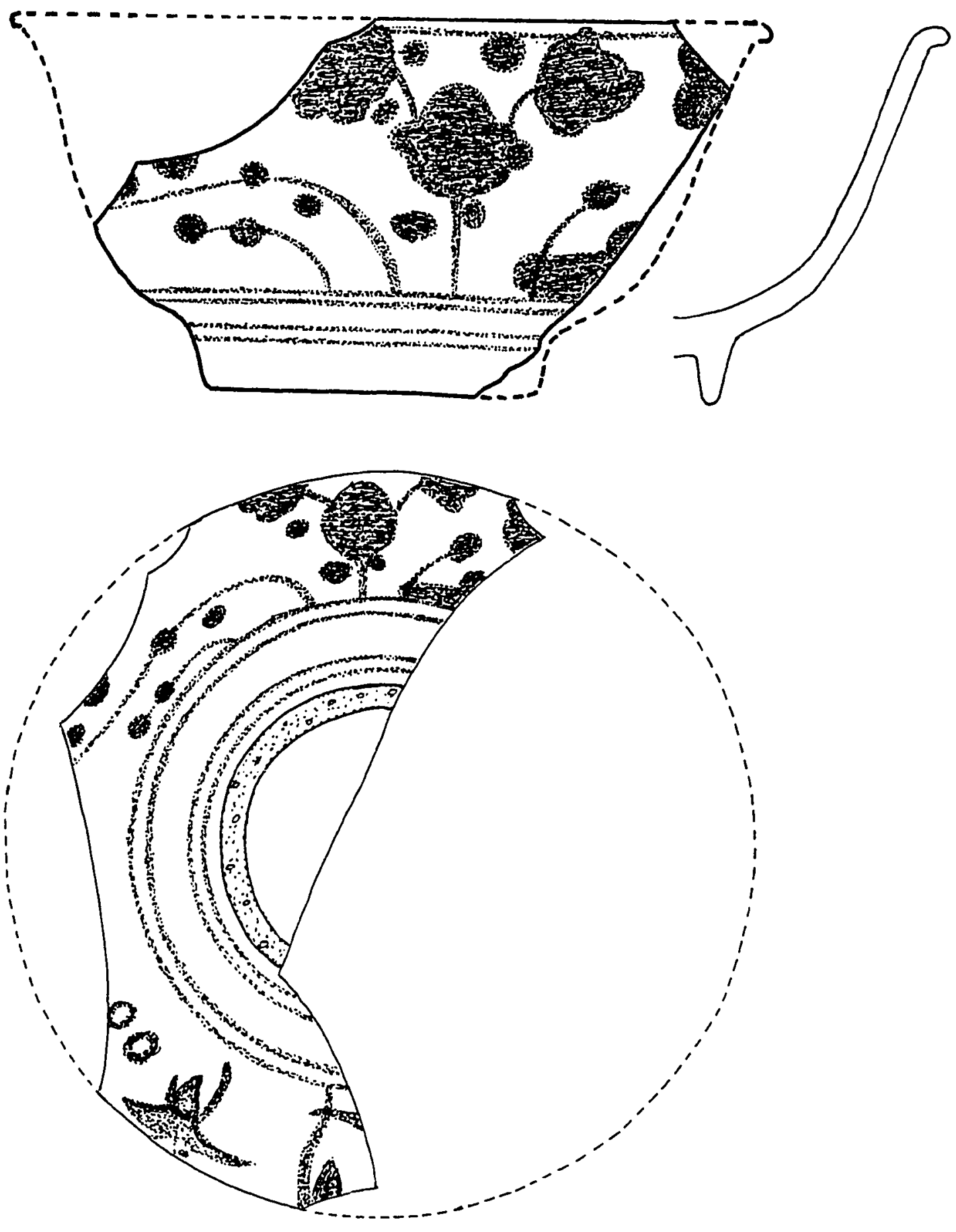

Figure 21. BAMBOO Type, including exterior wall and shoulder design. (Est. dia. $12.2 \mathrm{~cm}$ ). 


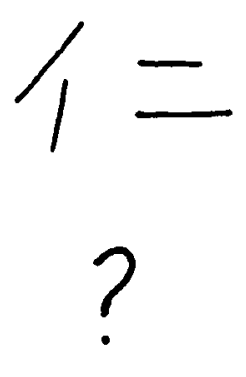

\# 3-16
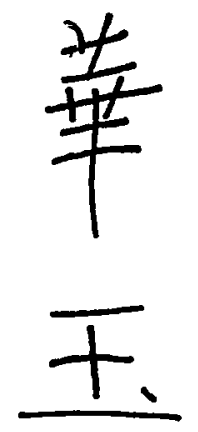

$\# 5-410$

$\frac{1}{15}$

$\frac{7}{31}$

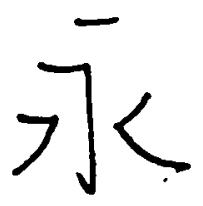

7

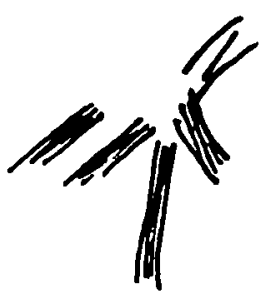

\#3-18

$\# 5-318$

$5-409$

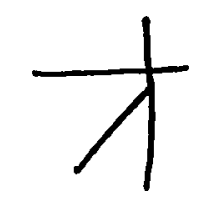

$\frac{1}{11}$

$\# 5-411$

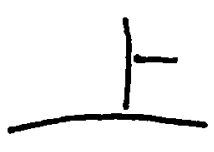

$\widehat{\square}$

$\# 10-126$

\#11-4

Figure 22. Chinese characters within footring of BAMBOO type (see Table 10 for translations). 

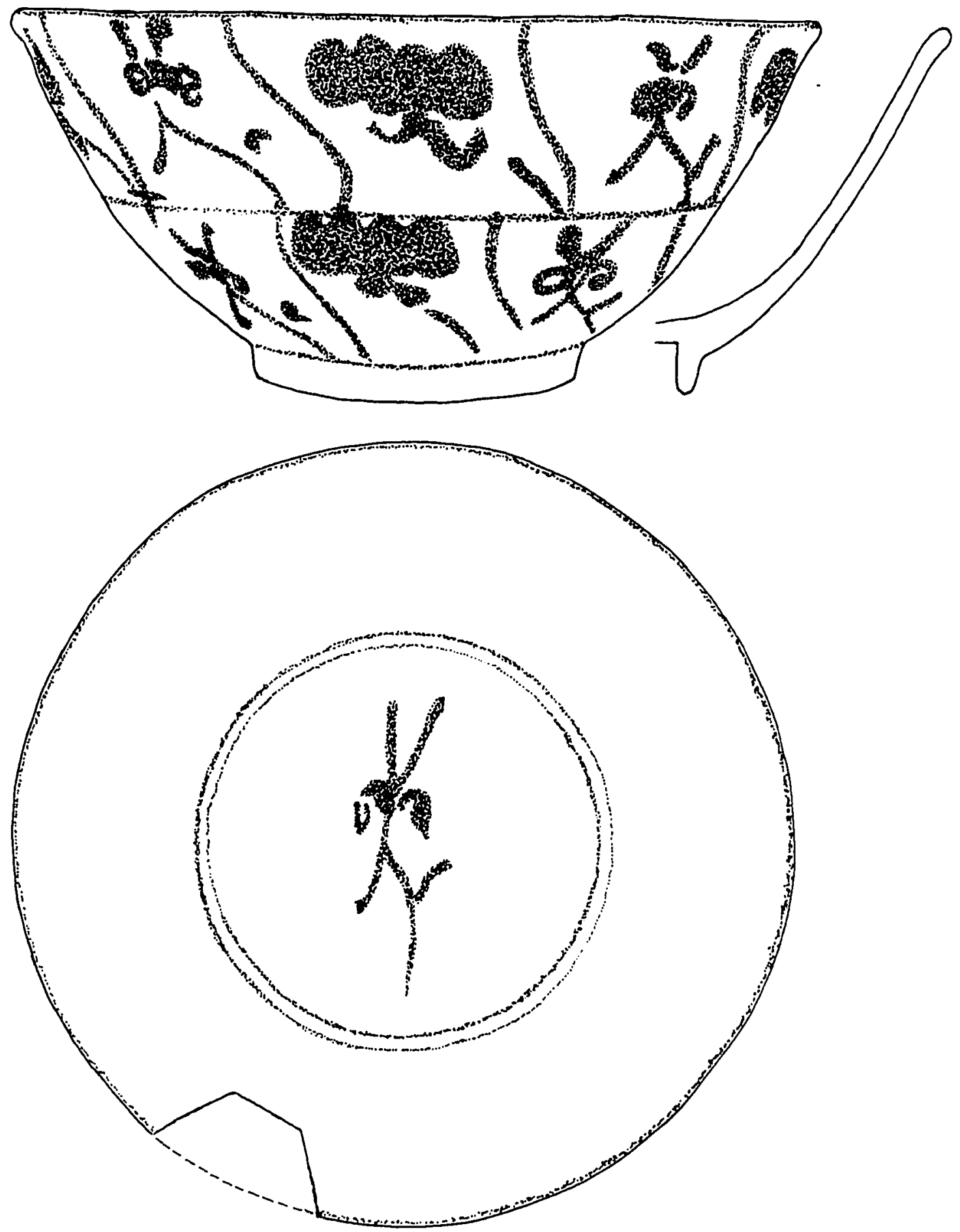

Figure 23. PEACH \& FUNGUS Type, including well and cavetto design (dia. $15.5 \mathrm{~cm}$ ). 


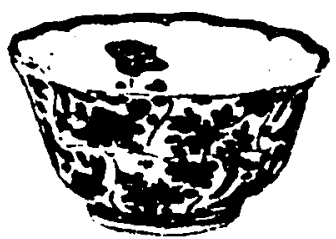

17 th century
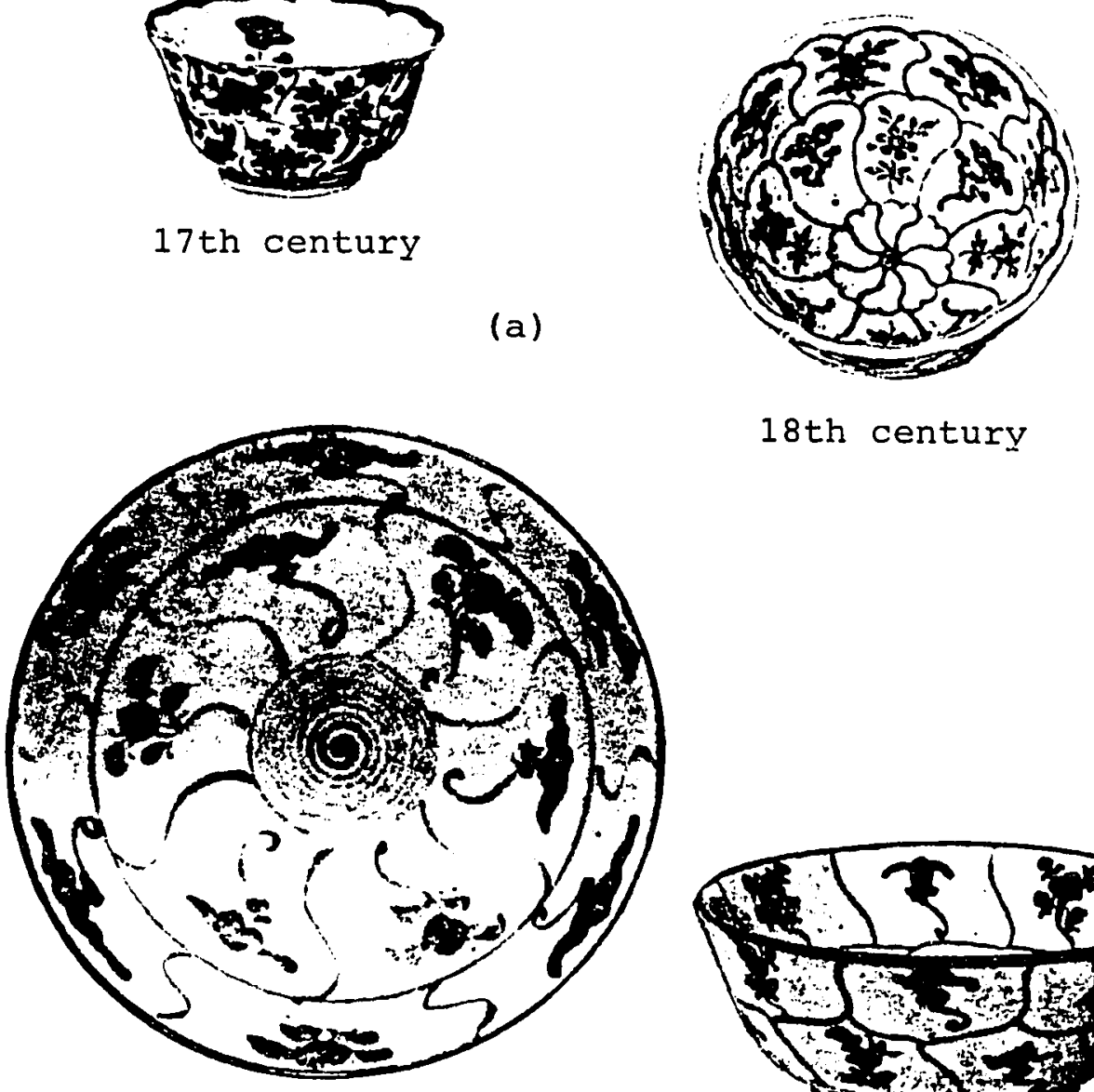

18 th century

19 th century

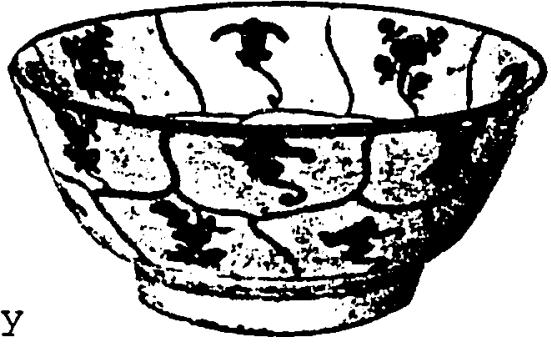

(b)

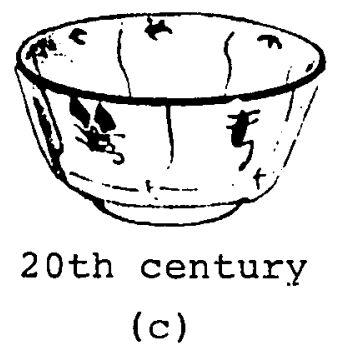

Figure 24. Devolution of PEACH \& FUNGUS motif from 17 th to 20 th century. 


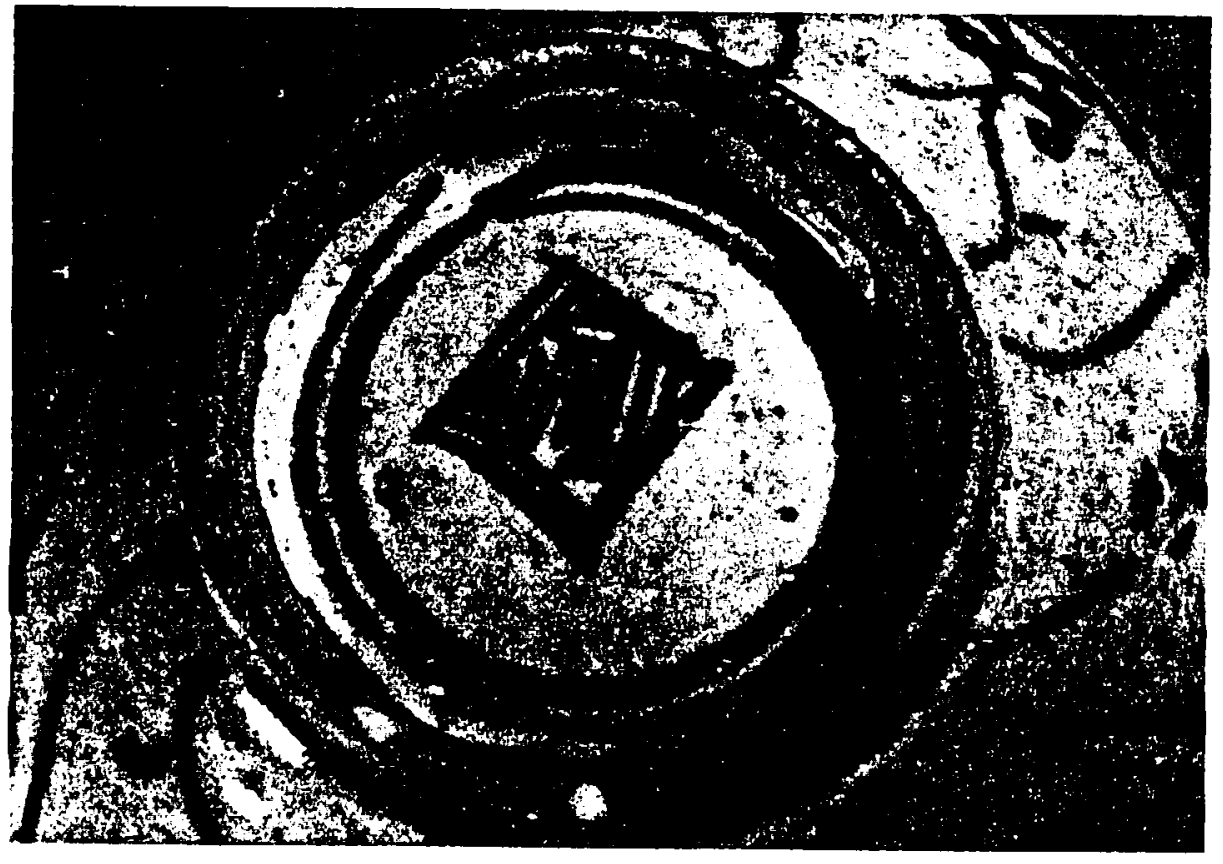

Figure 25. Central character inside footring of PEACH \& FUNGUS type. 

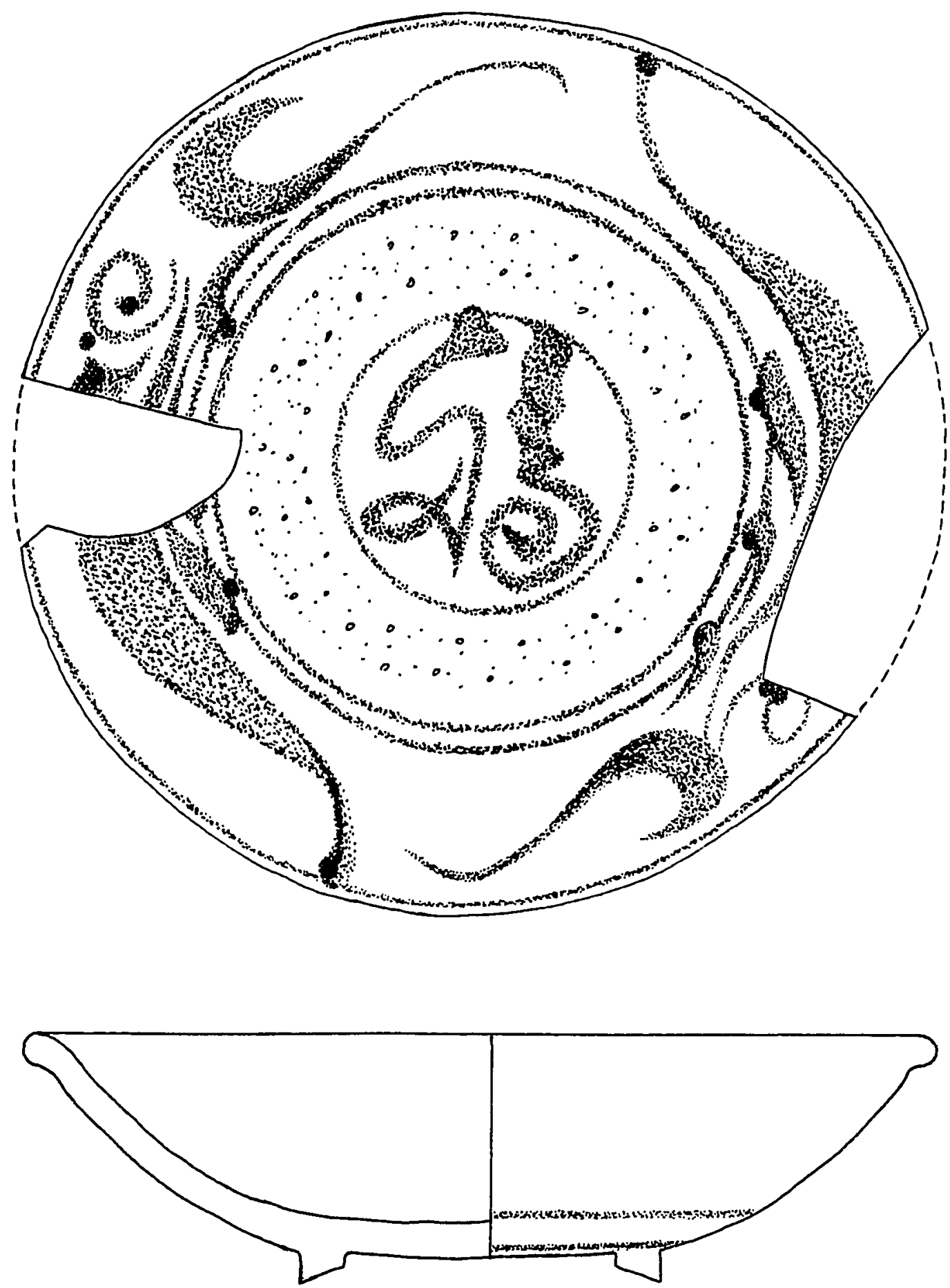

Figure 26. FU Type (dia. 25.6-25.7 cm). 

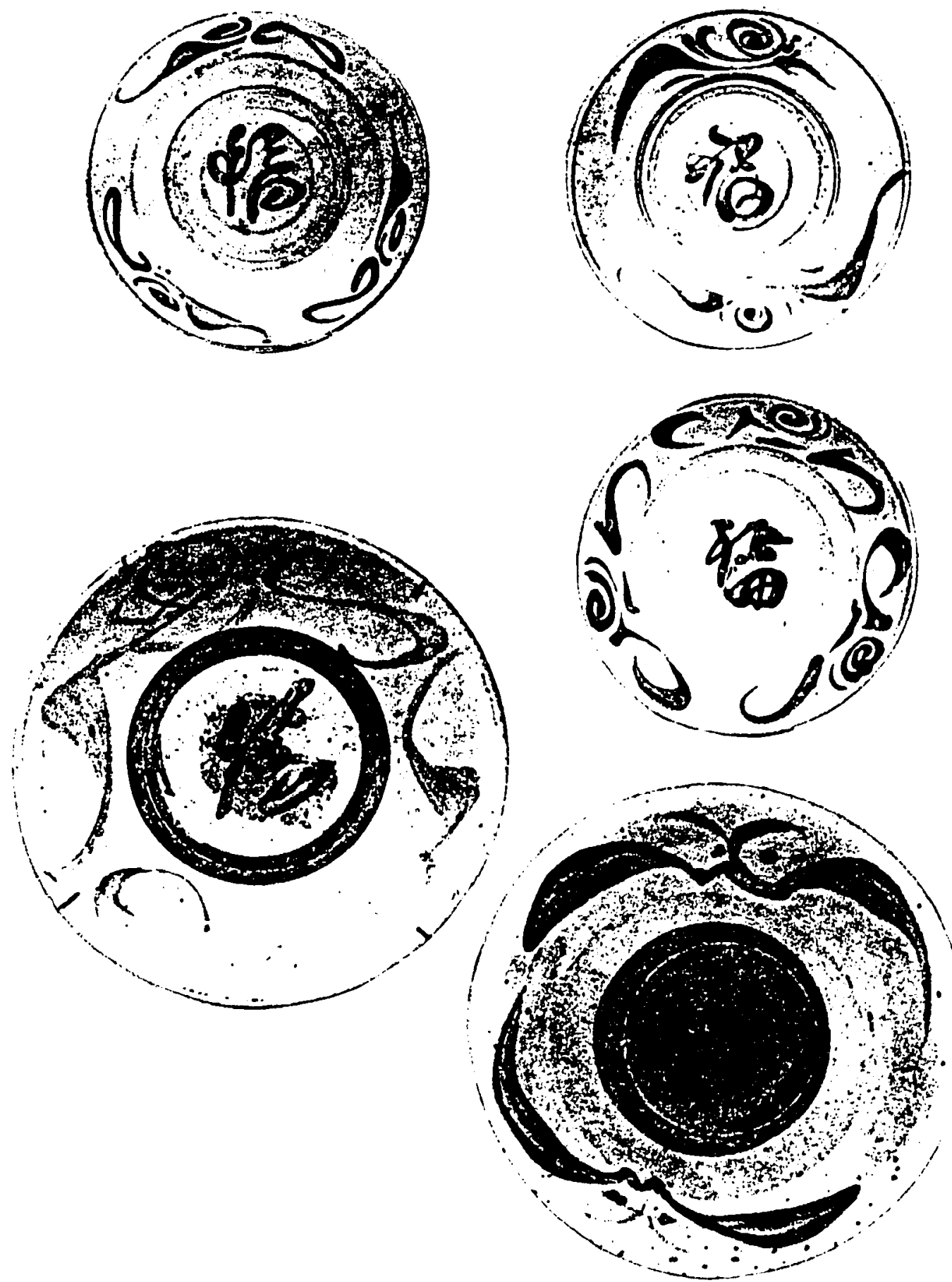

Figure 27. Nineteenth and twentieth century $f u$ bowls. Illustrations from Willetts and Lim (1981:82). 

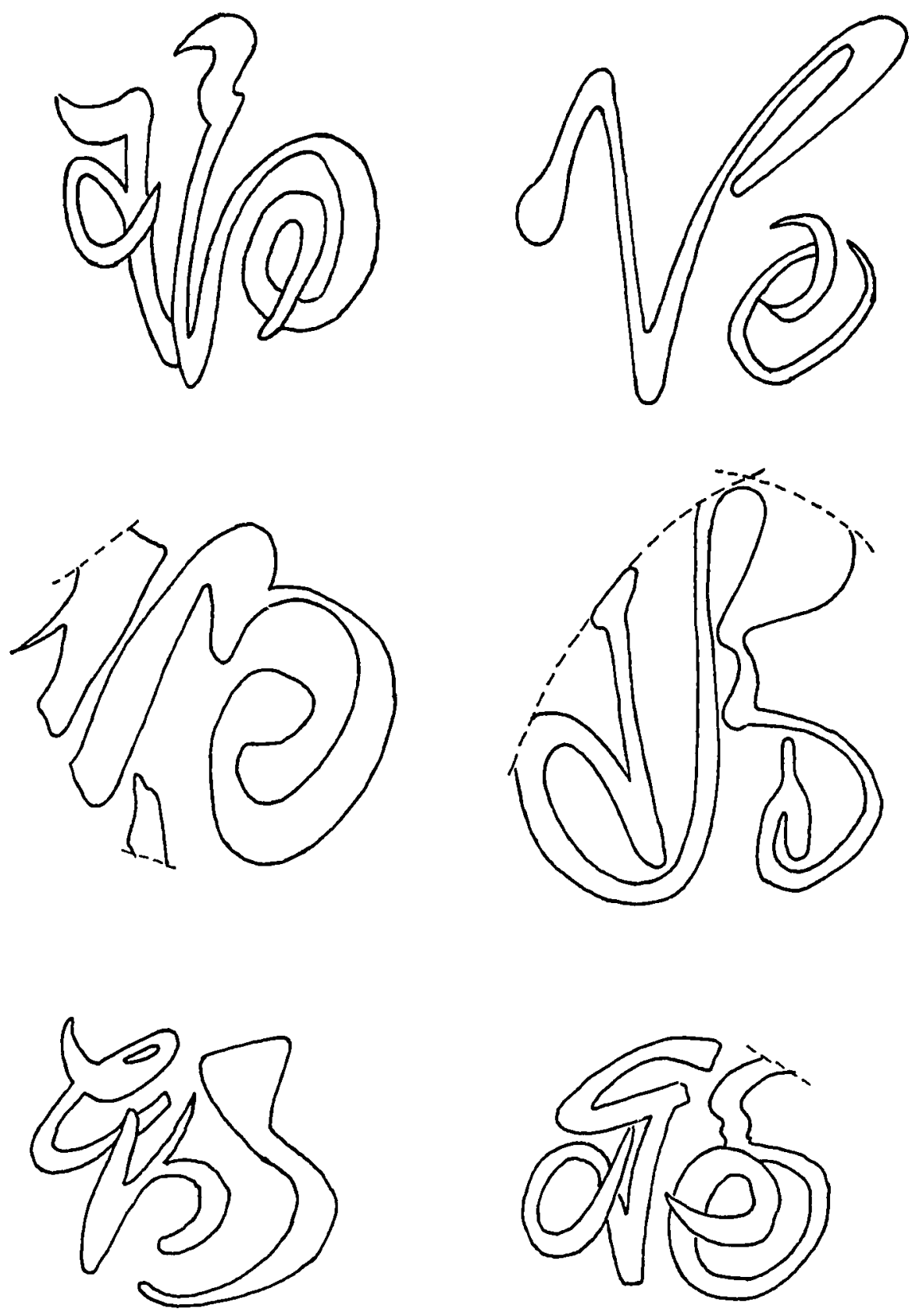

Figure 28. Variations of $f u$ character on FU Type sherds. 

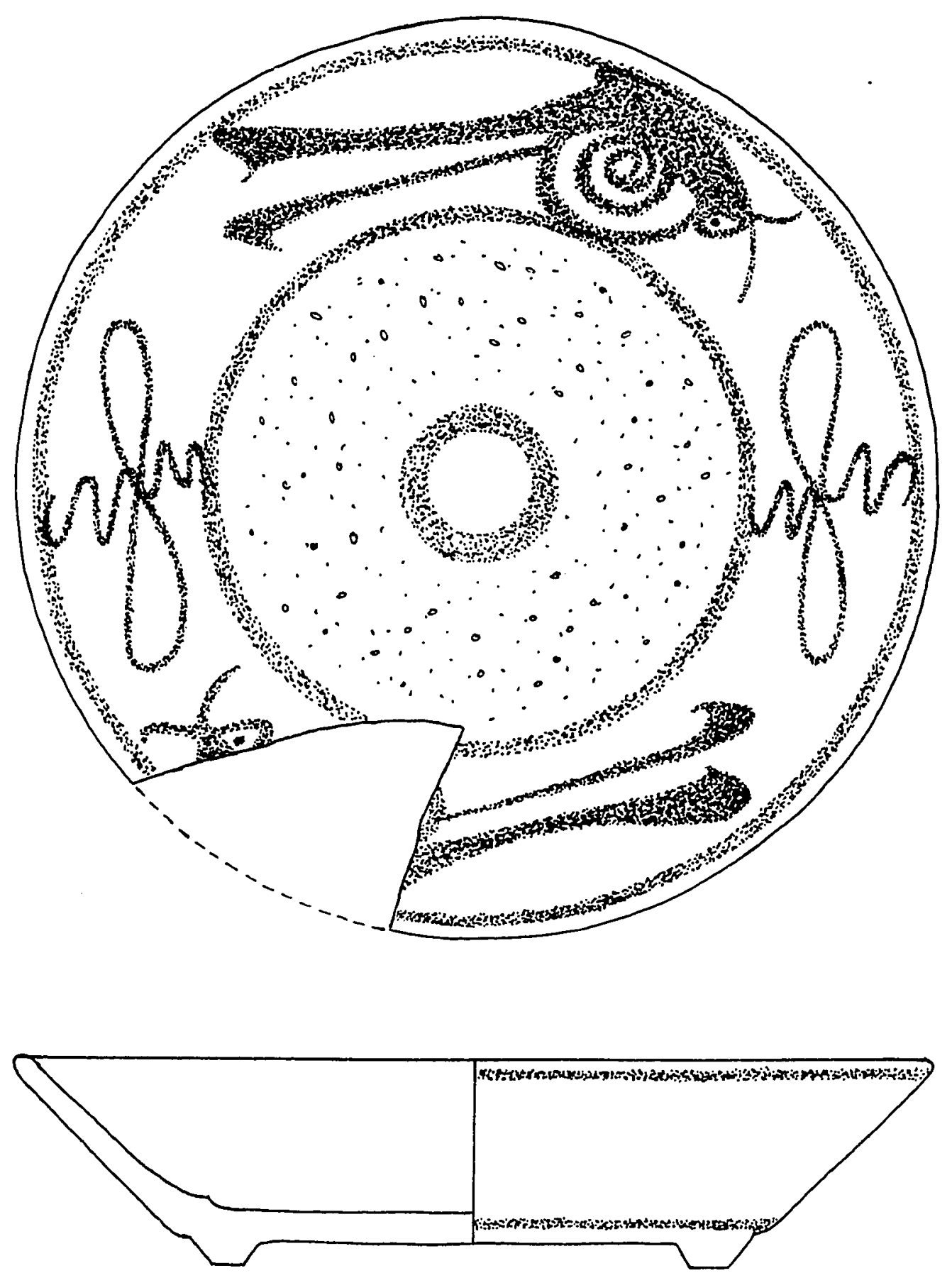

Figure 29. SNAIL Type (dia. 17.2-18.0 cm). 

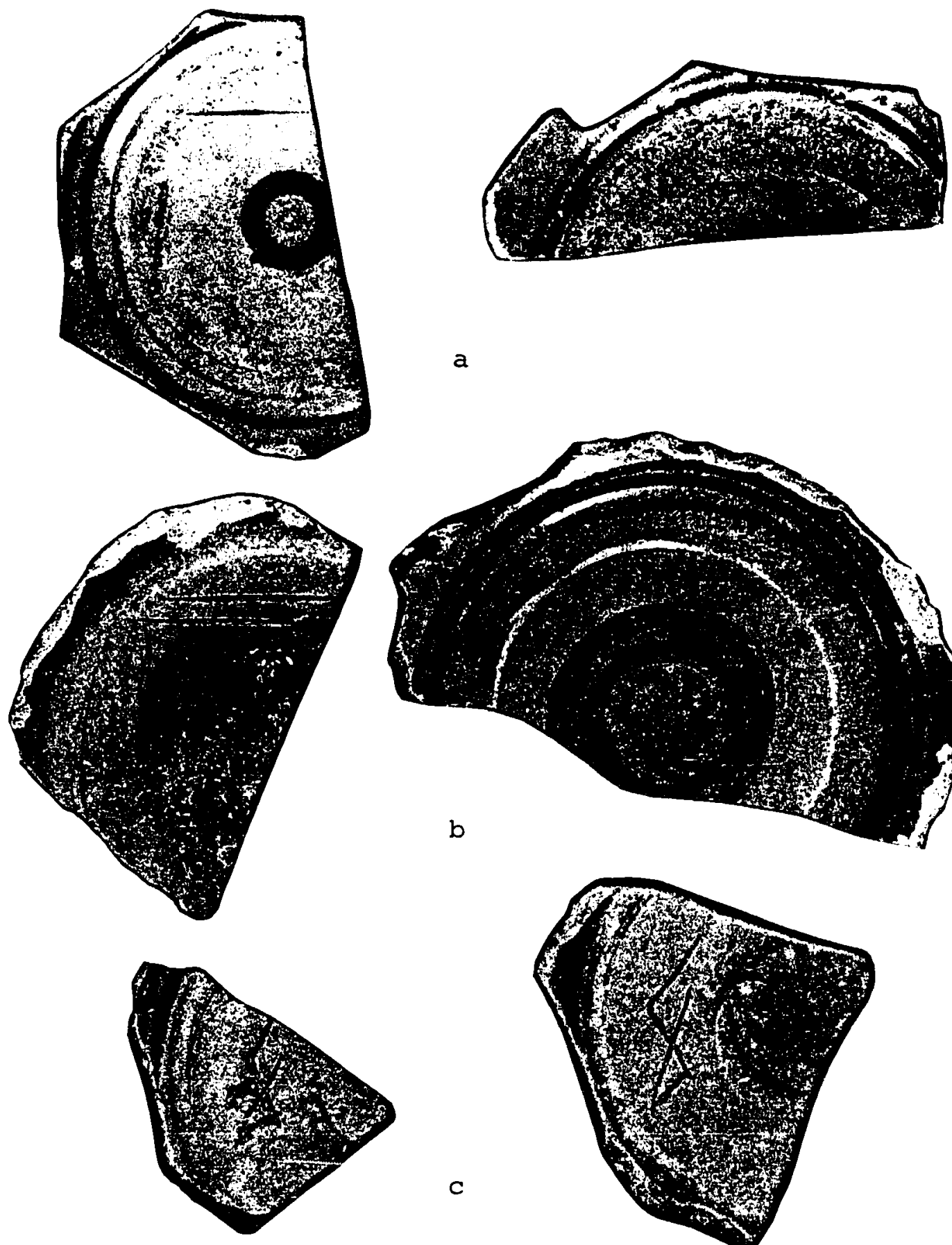

a

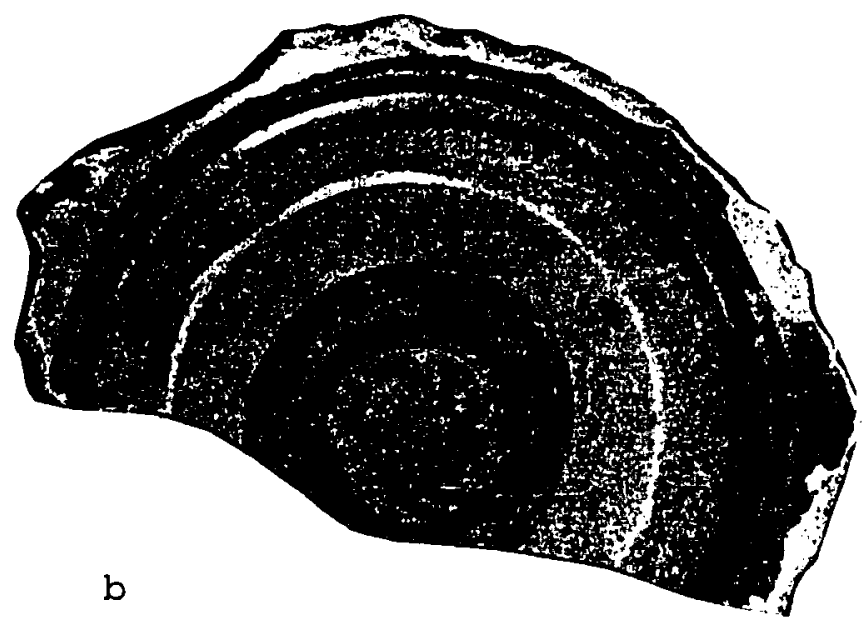

C

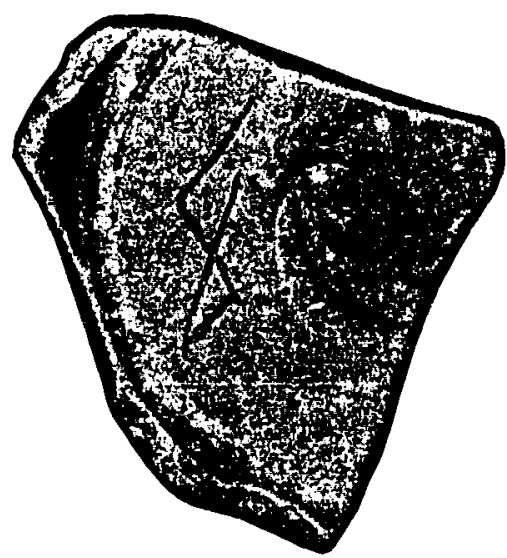

Figure 30. Chinese tally marks representing numbers
a) one
b) two
- , and
c) five $\overline{7}$. 

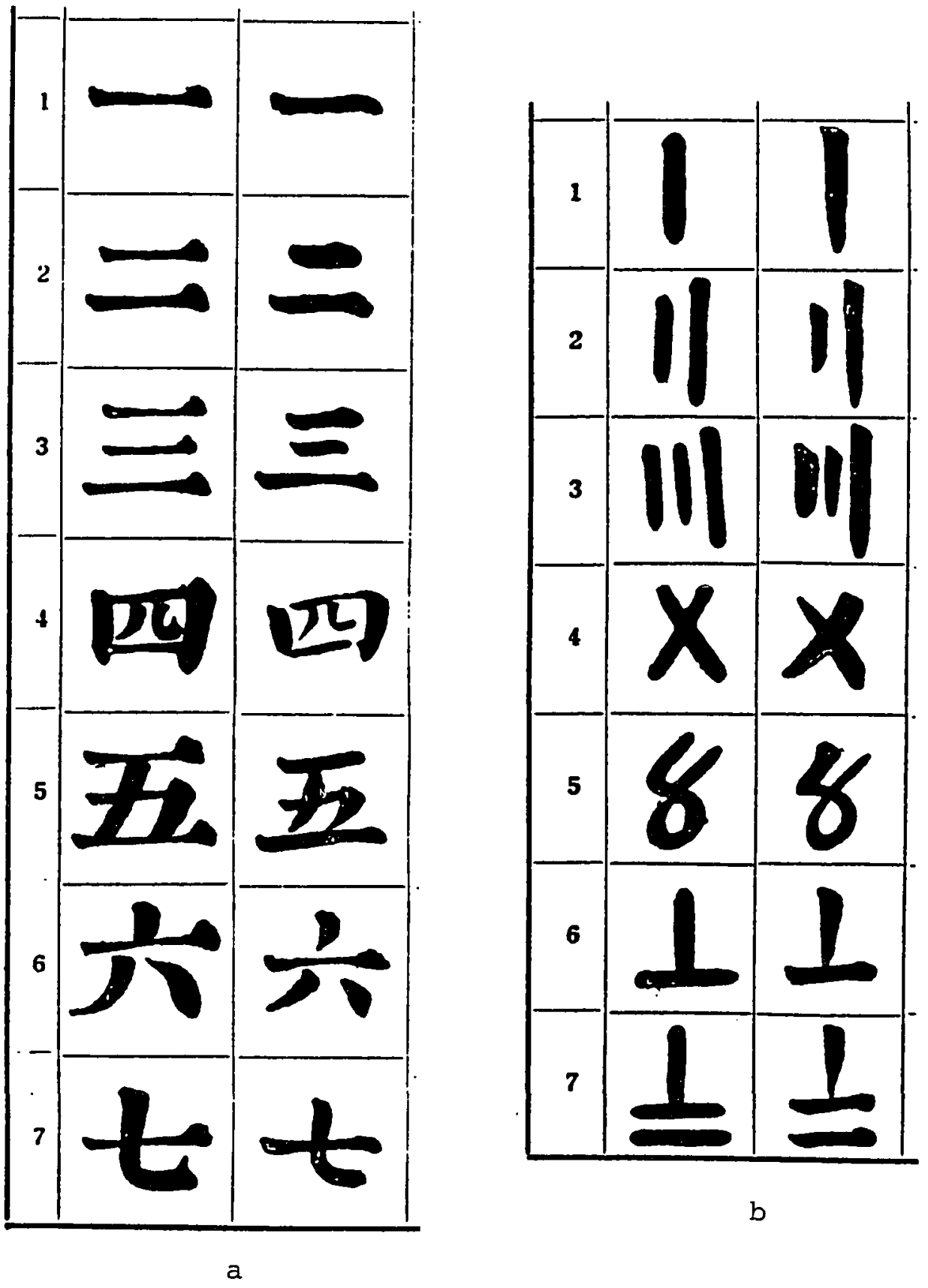

Figure 31. a) Traditional representation of Chinese numbers. b) Simplified style used in merchandise inventories and warehouse tallies. Illustration from Glathe $(1932: 4,9)$. 

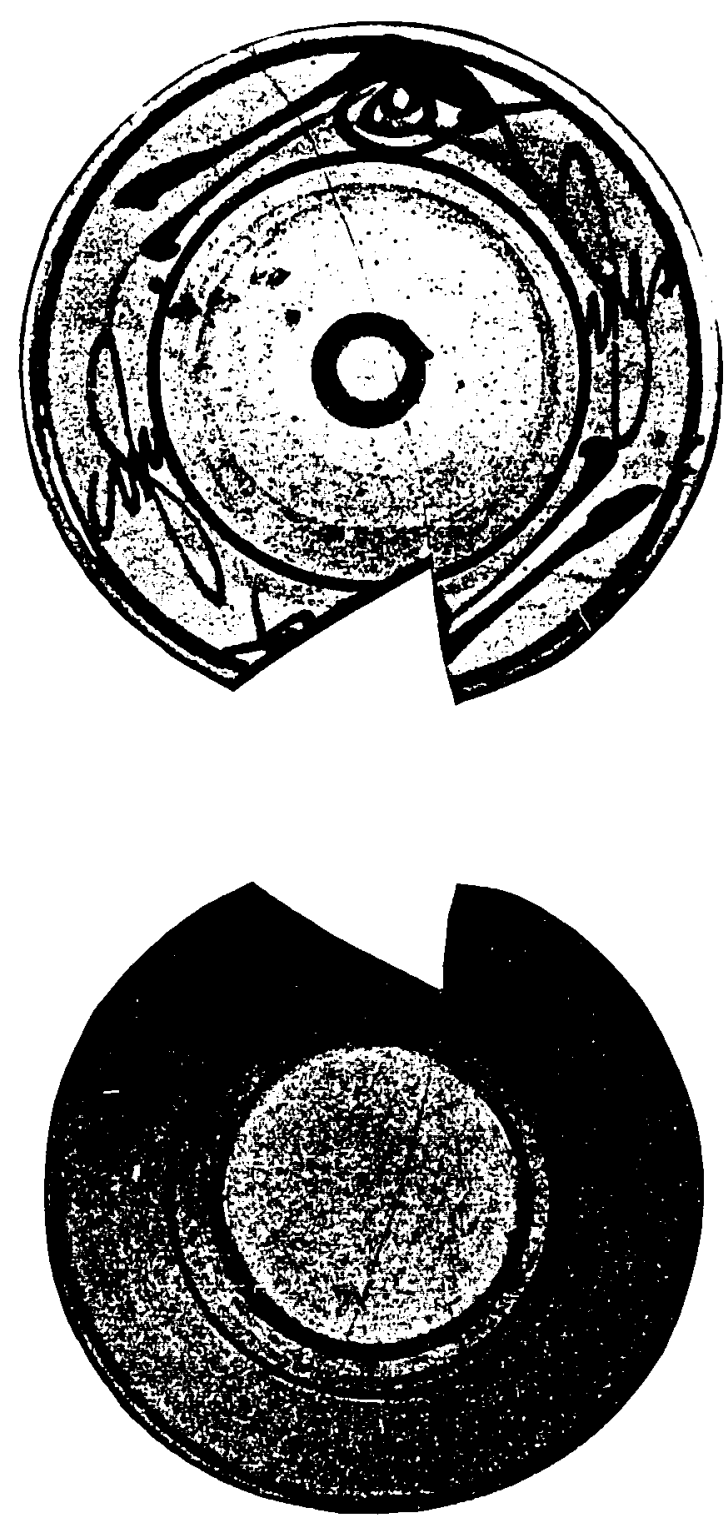

Figure 32. SNAIL Type, Variety $A$ (dia. 17.2-17.8 cm). 

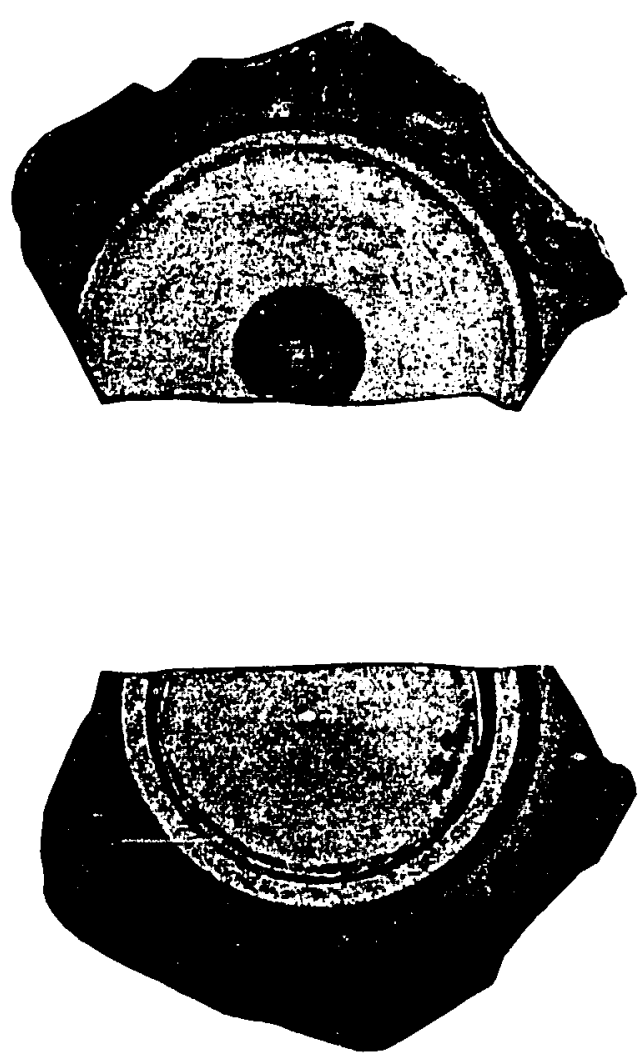

Figure 33. SNAIL Type, Variety B (dia. unknown). 

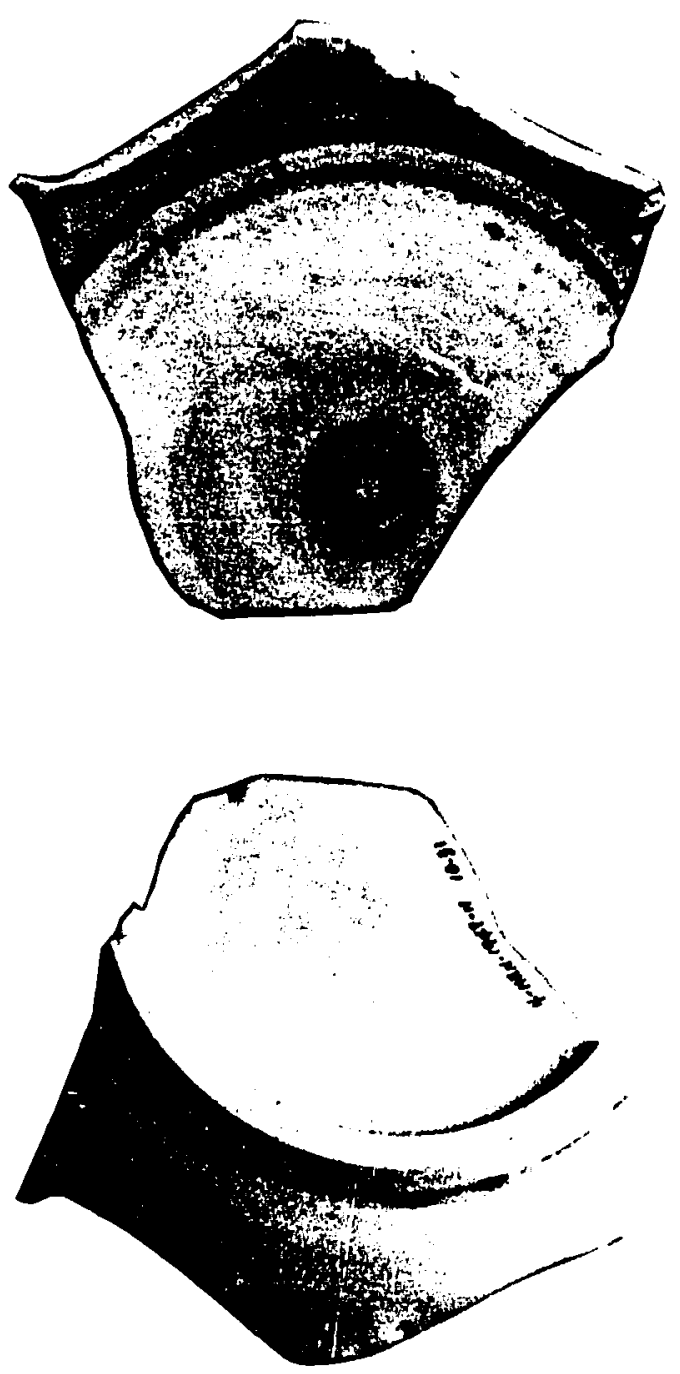

Figure 34. SNAIL Type, Variety C (dia. unknown). 

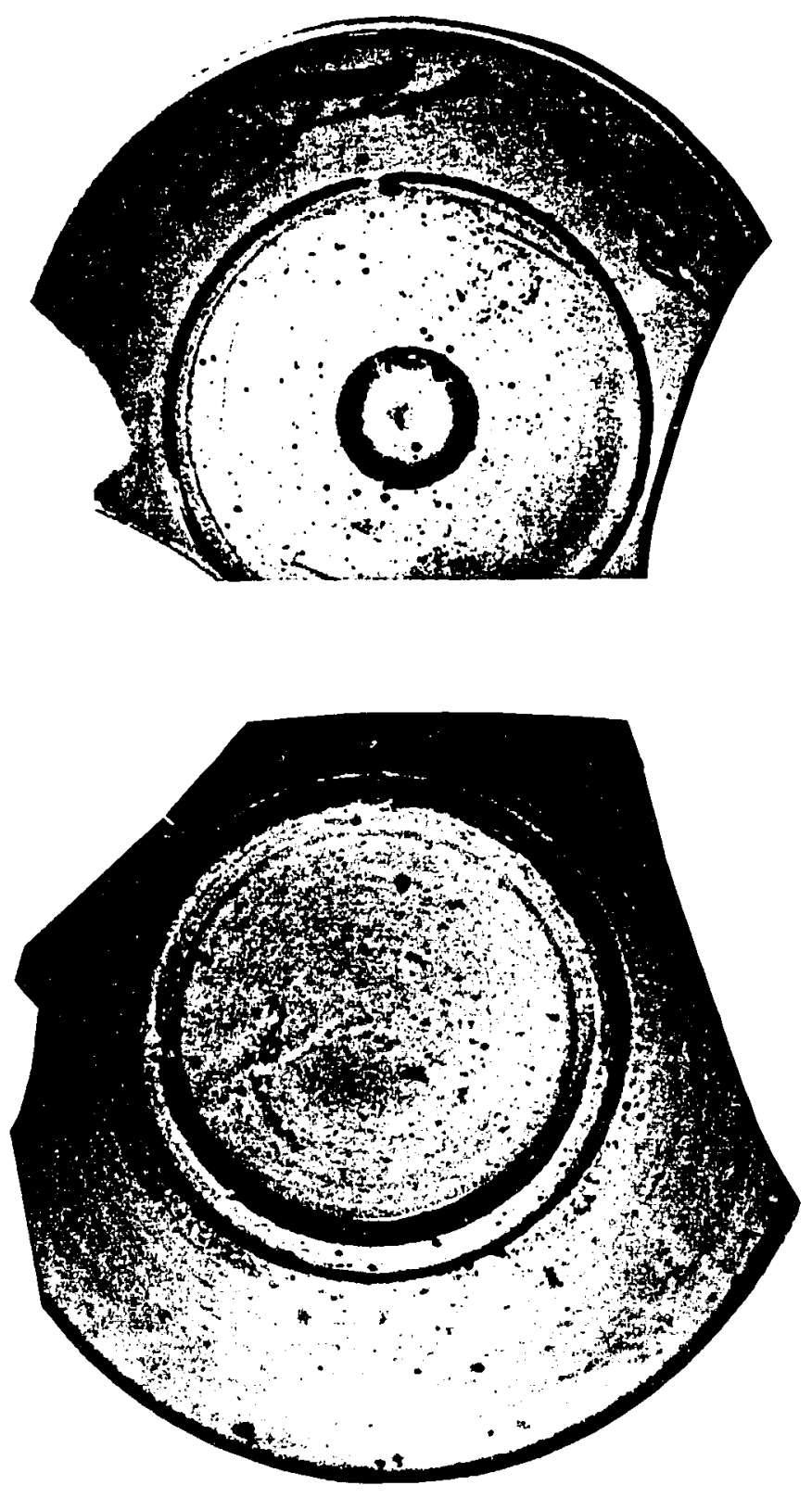

Figure 35. SNAIL Type, Variety D (dia. $17.8-18.0 \mathrm{~cm}$ ). 

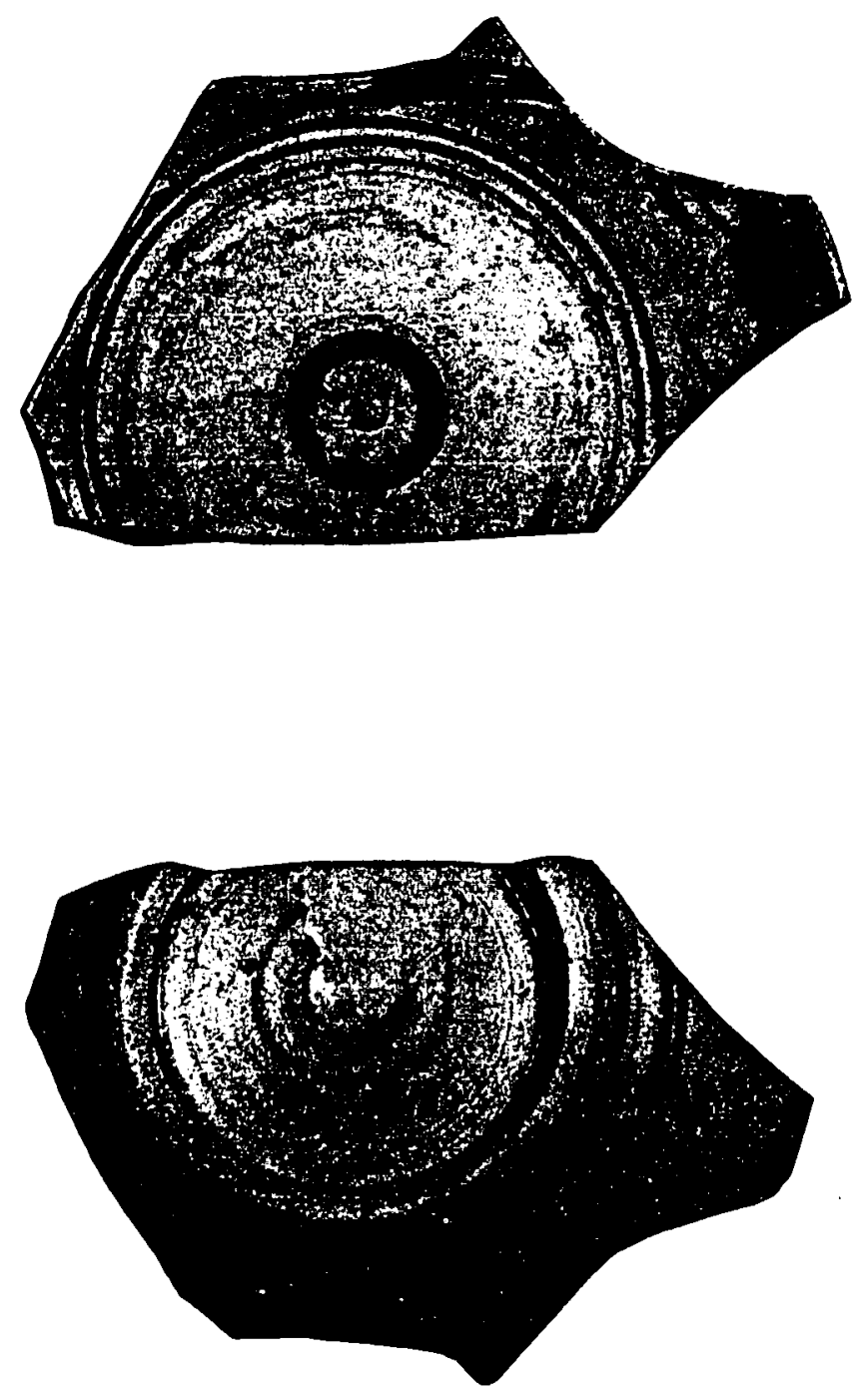

Figure 36. SNAIL Type, Variety E (dia. unknown). 

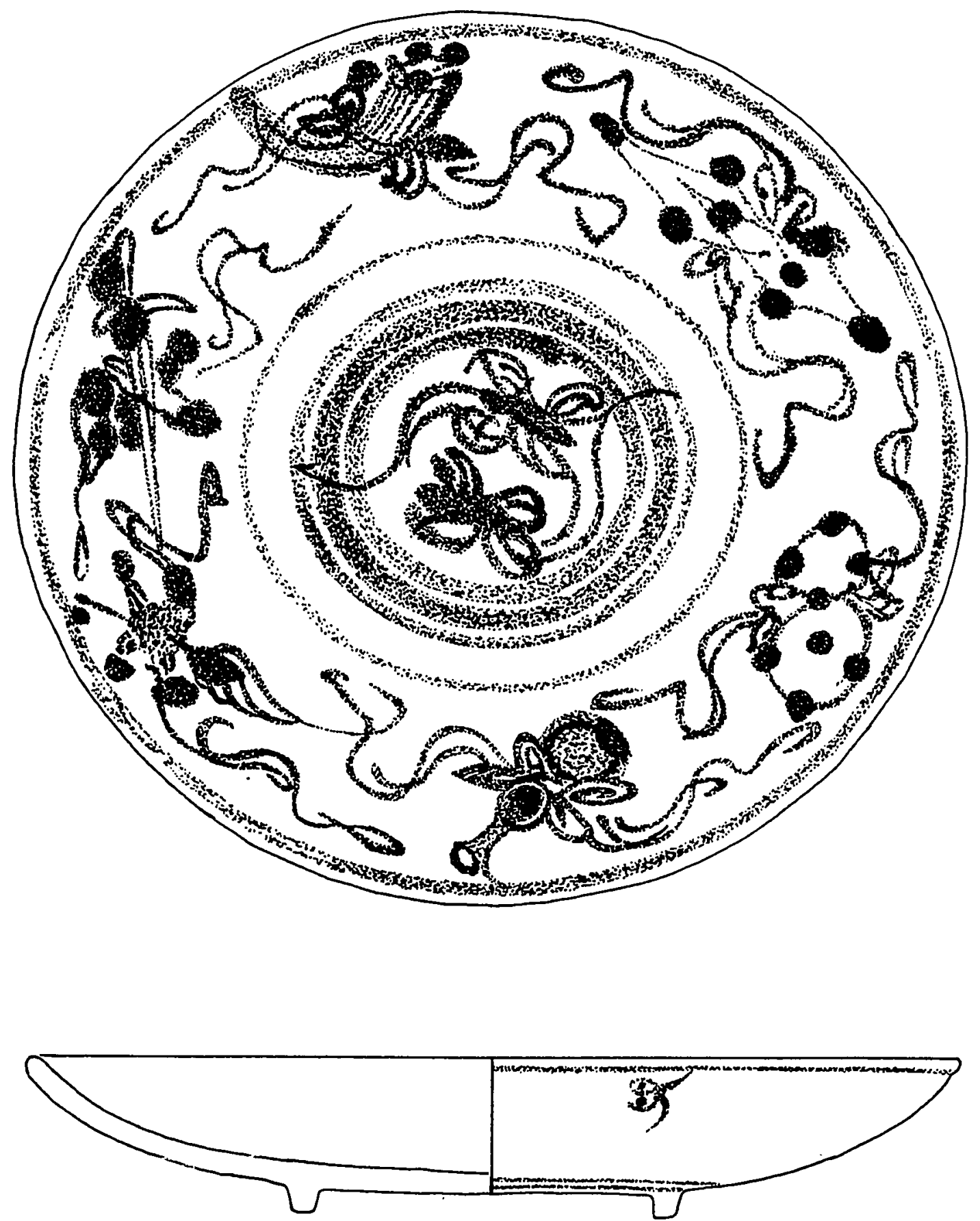

Figure 37. SIX TREASURES Type (dia. $16.5 \mathrm{~cm}$ ). 


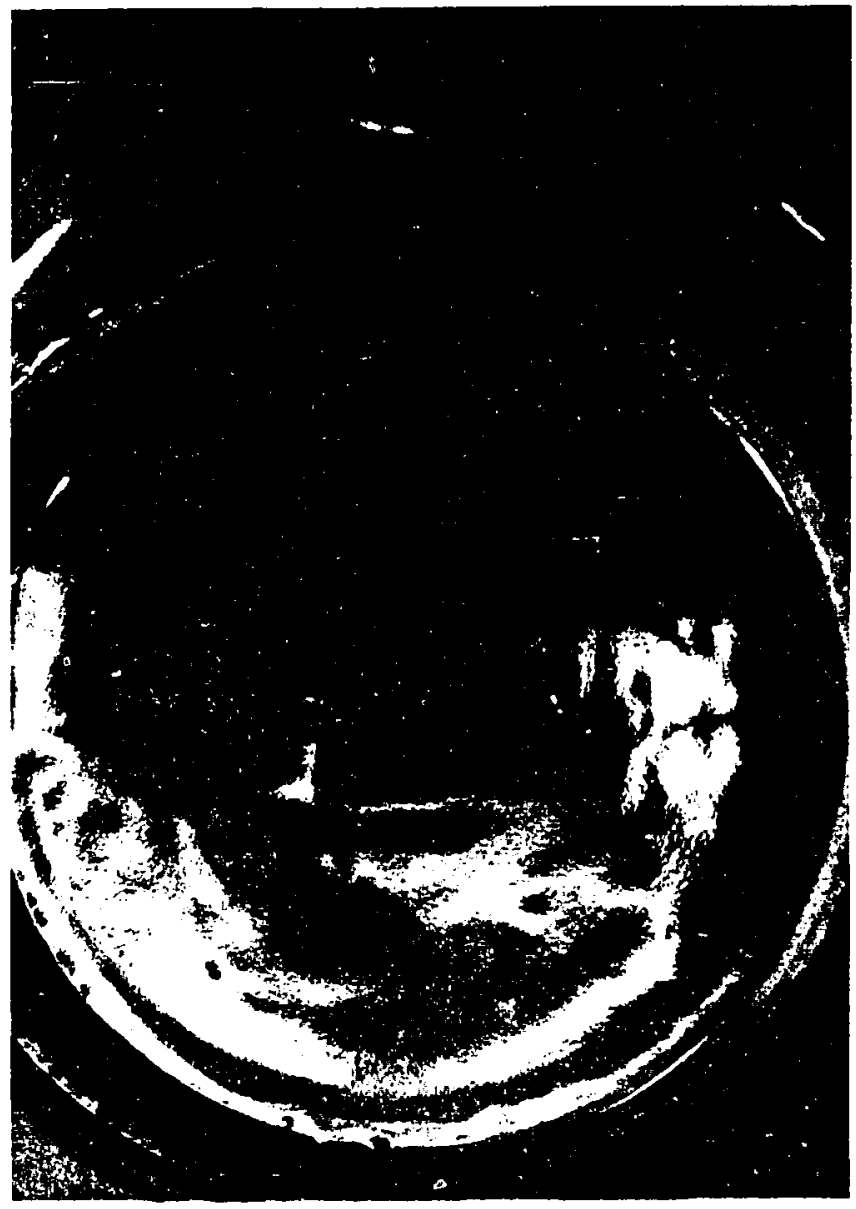

Figure 38. Central character inside footring of SIX TREASURES Type. 

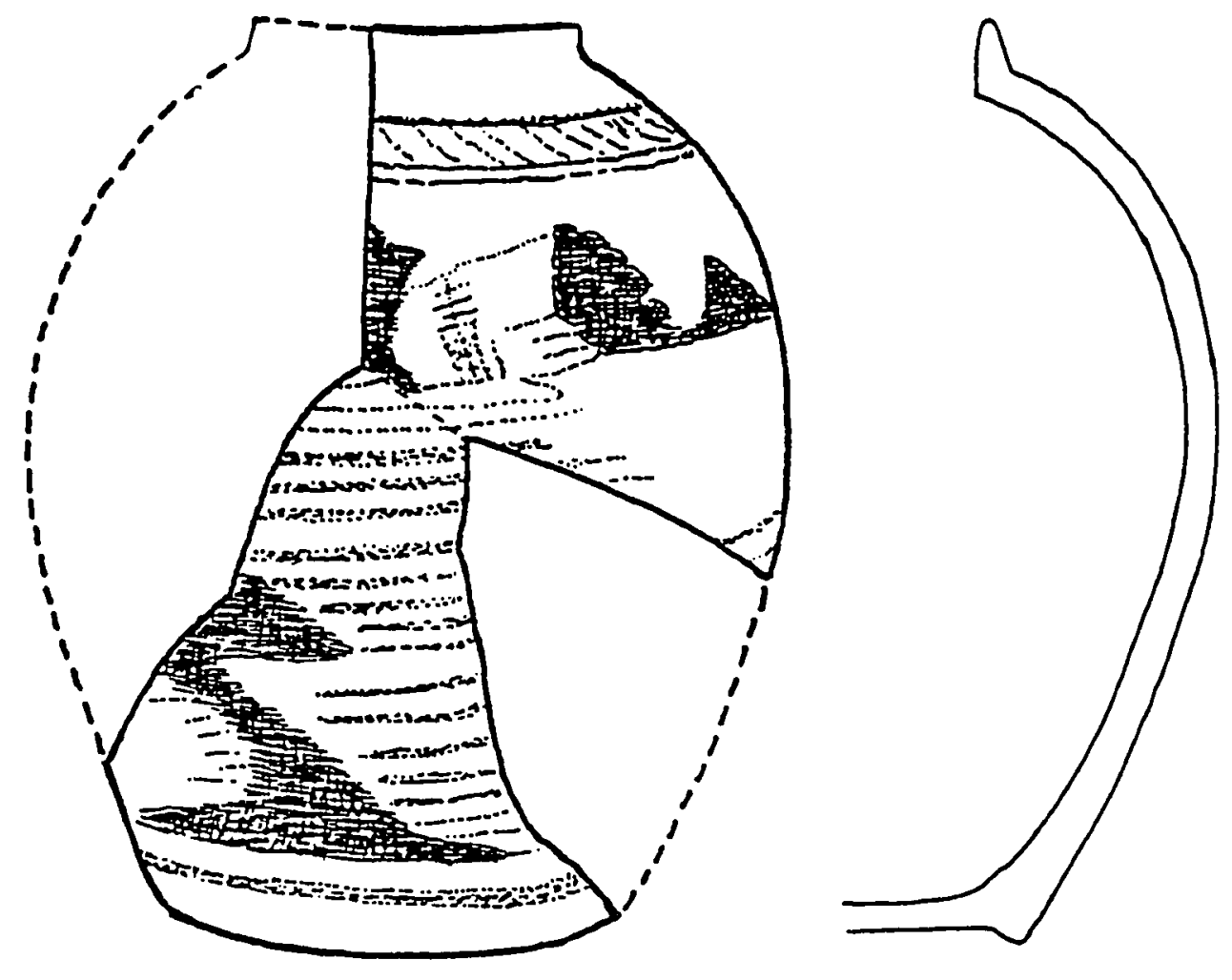

Figure 39. GINGER JAR Type (ht. $16.6 \mathrm{~cm}$ ). 

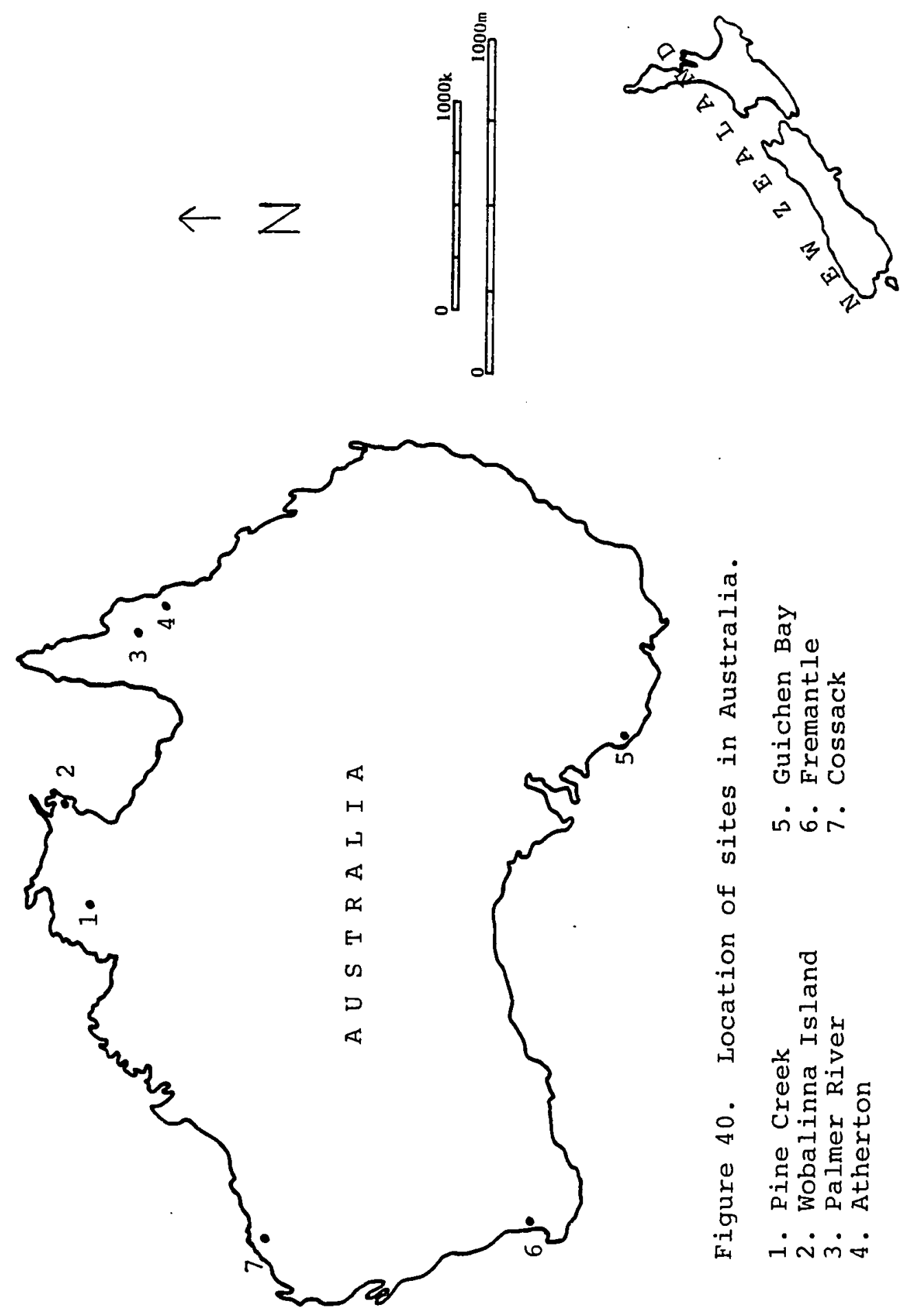


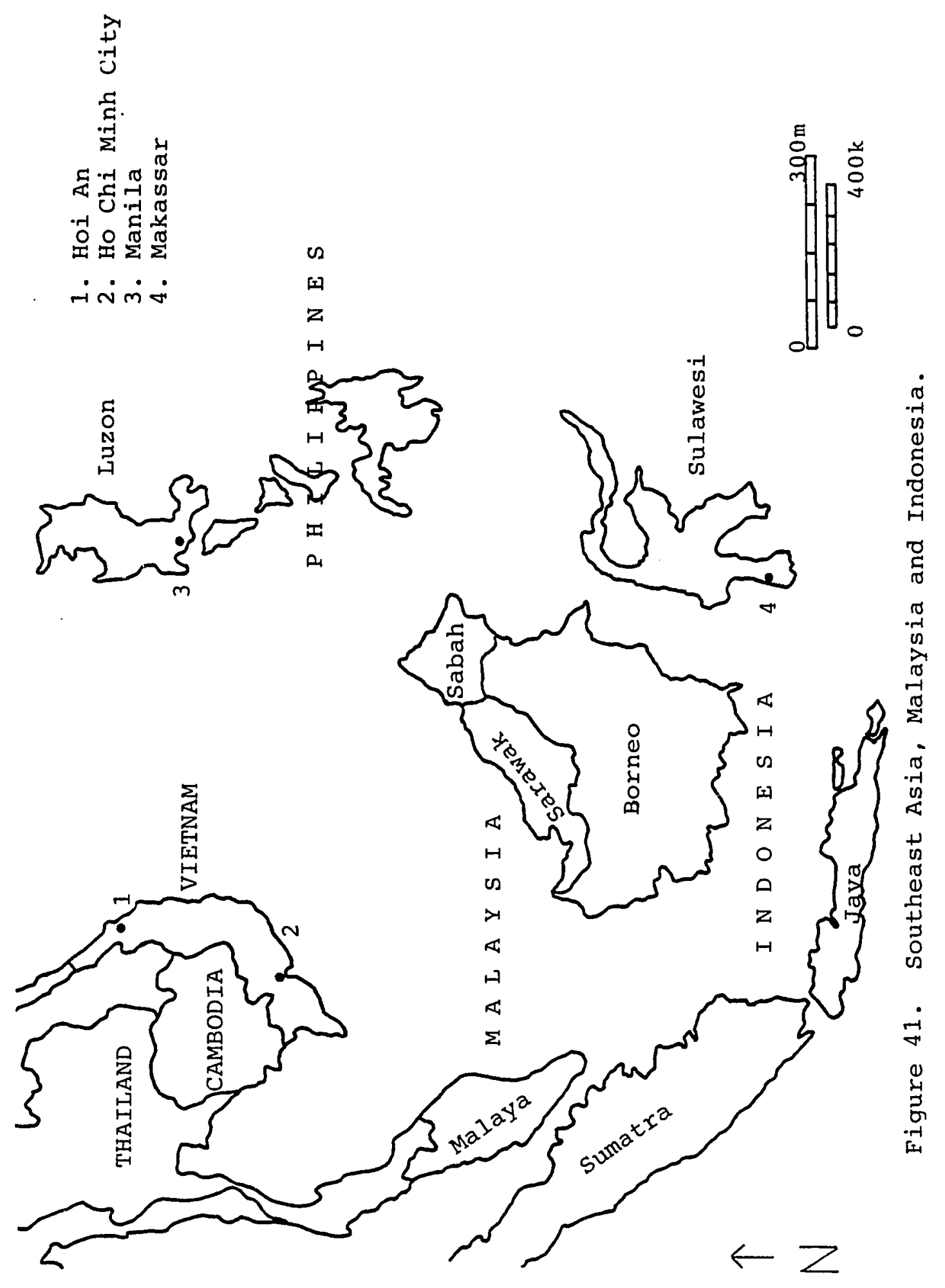




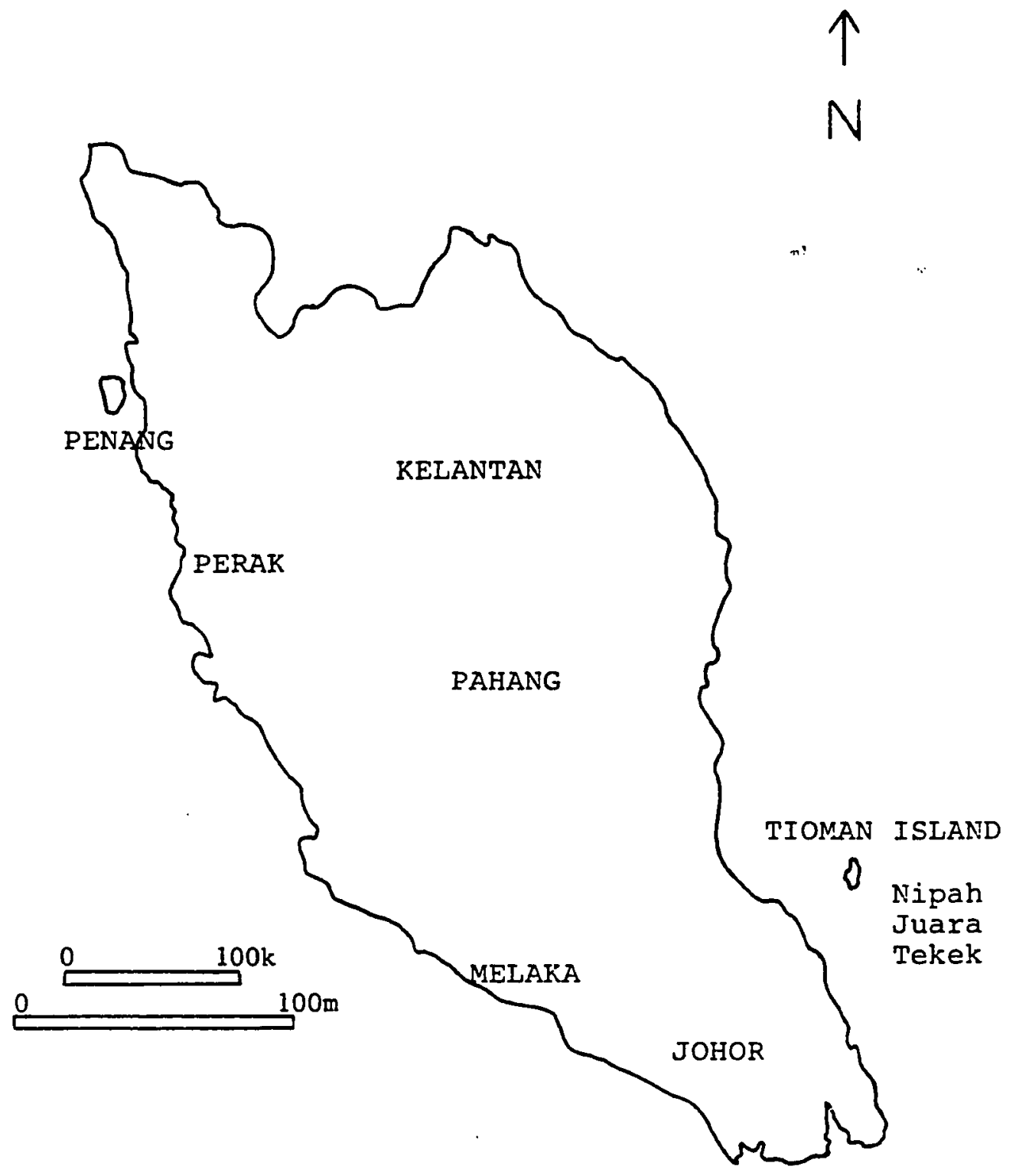

Figure 42. Malaya 


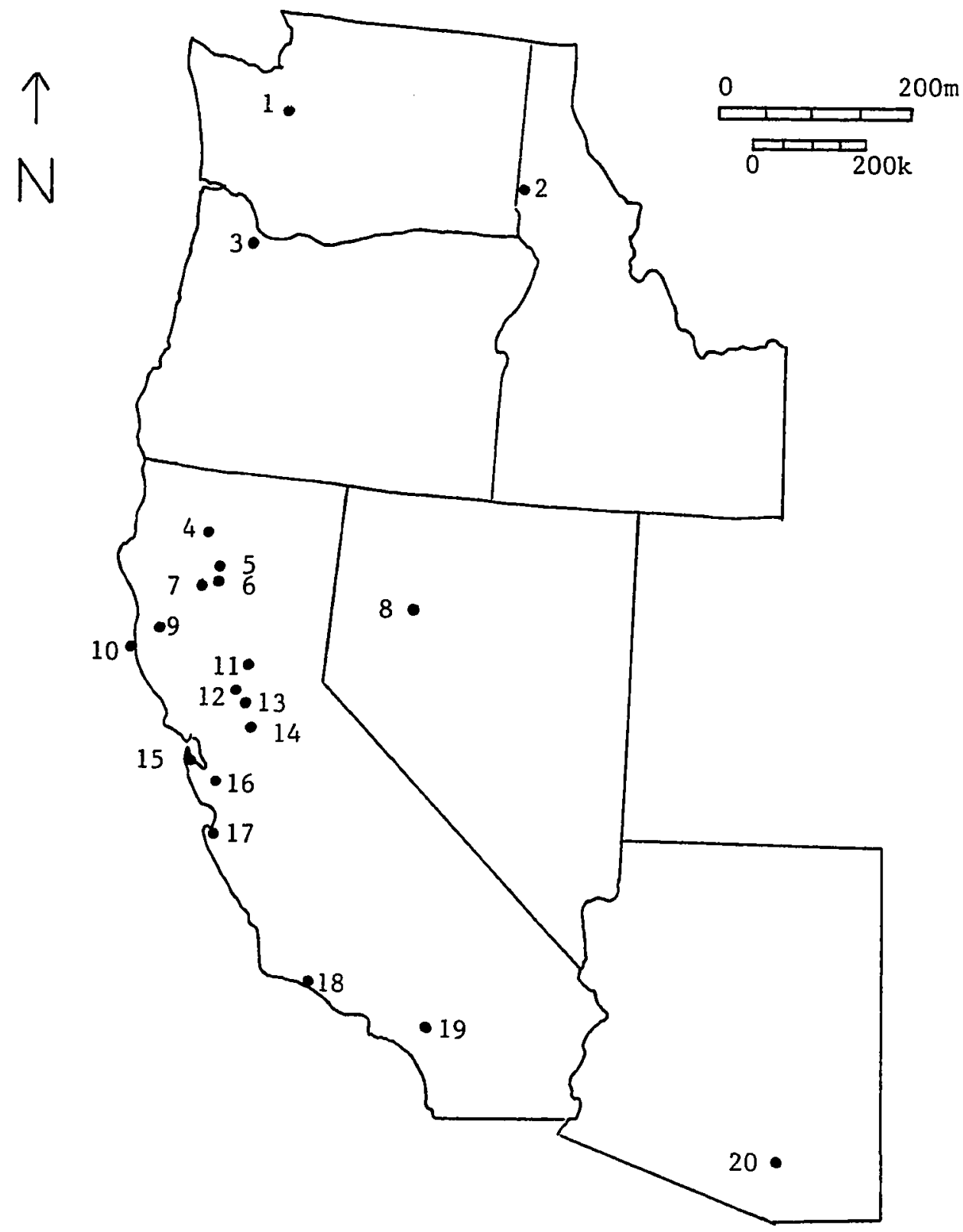

Figure 43. Western United States sites and comparative collections.
1. Seattle
8. Lovelock
14. Walnut Grove
2. Moscow
3. Portland
9. Three Chop Village
15. San Francisco
4. Weaverville
10. Frolic shipwreck
16. San Jose
5. Redding
11. Marysville
12. Woodland
17. Monterey
6. Dutch Gulch
13. Sacramento
18. Ventura
19. Riverside
7. Igo \& Piety Hill
20. Tucson 

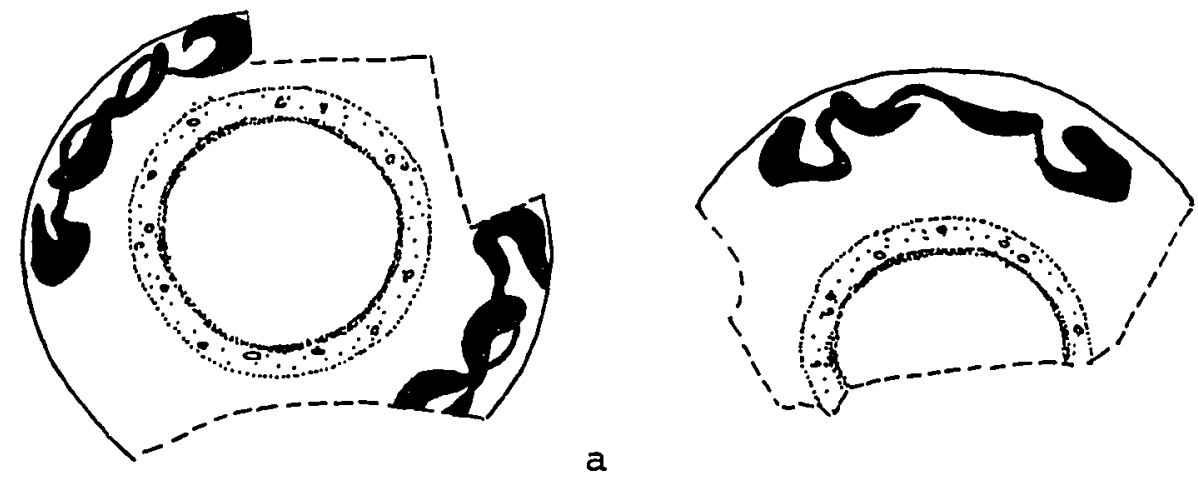

a

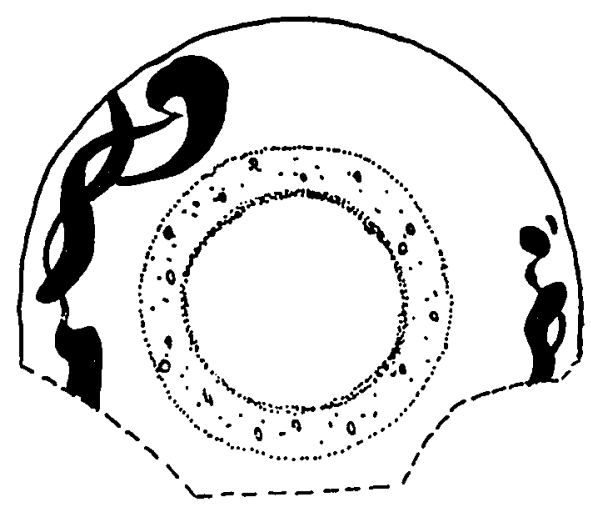

$\mathrm{b}$

a) Reverse view of "Southeast Asian" ware from Riverside. (Mueller 1987:289).

b) Reverse view of "saucer" from Tucson collection. (Lister \& Lister 1989:49).

Figure 44 


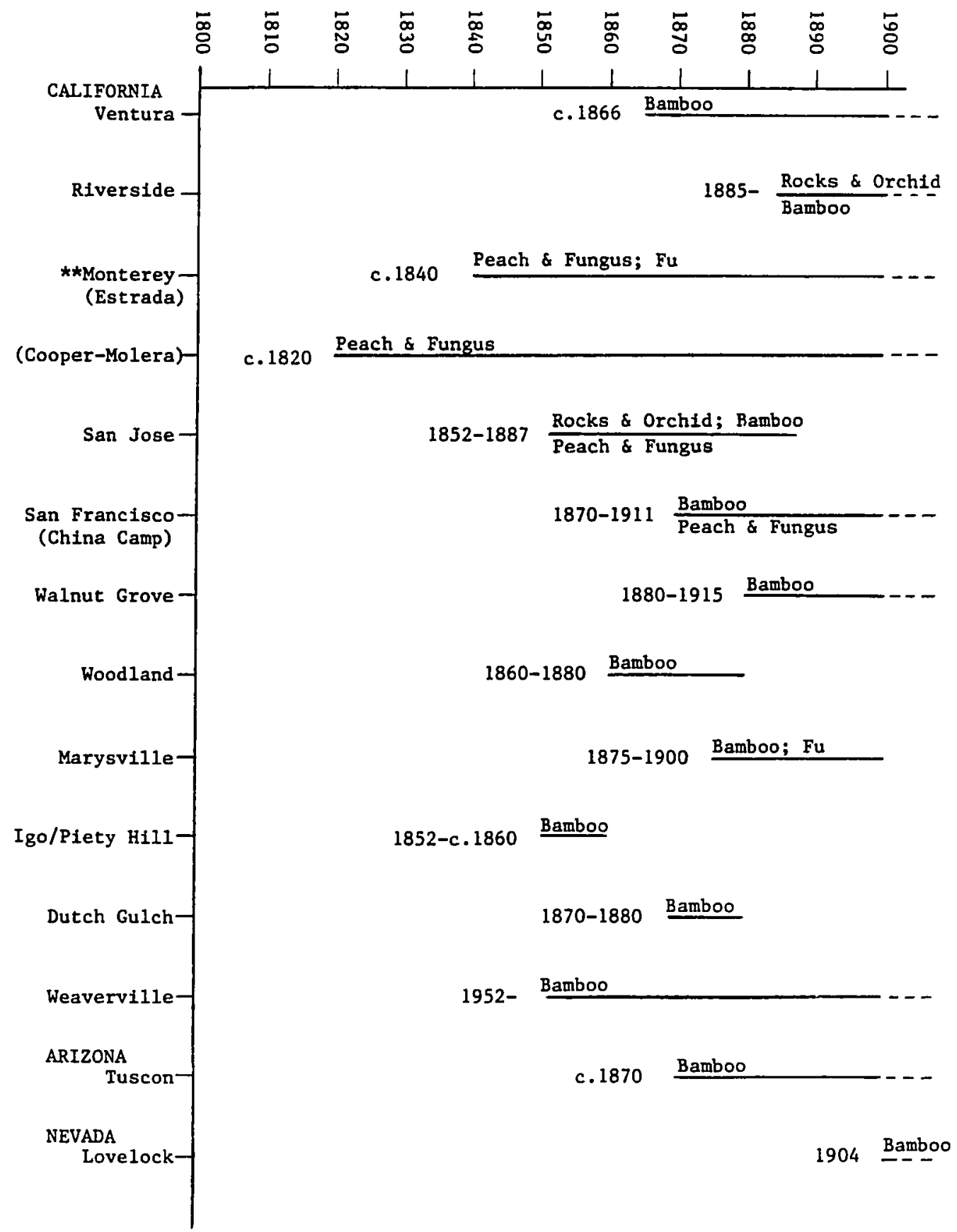

Figure 45. Periods of occupation during the nineteenth century in selected western United States sites, and occurrence of five Frolic ware types recovered from these sites.

**No Chinese occupation occurred at these two Monterey sites; all other sites had Chinese occupation. 

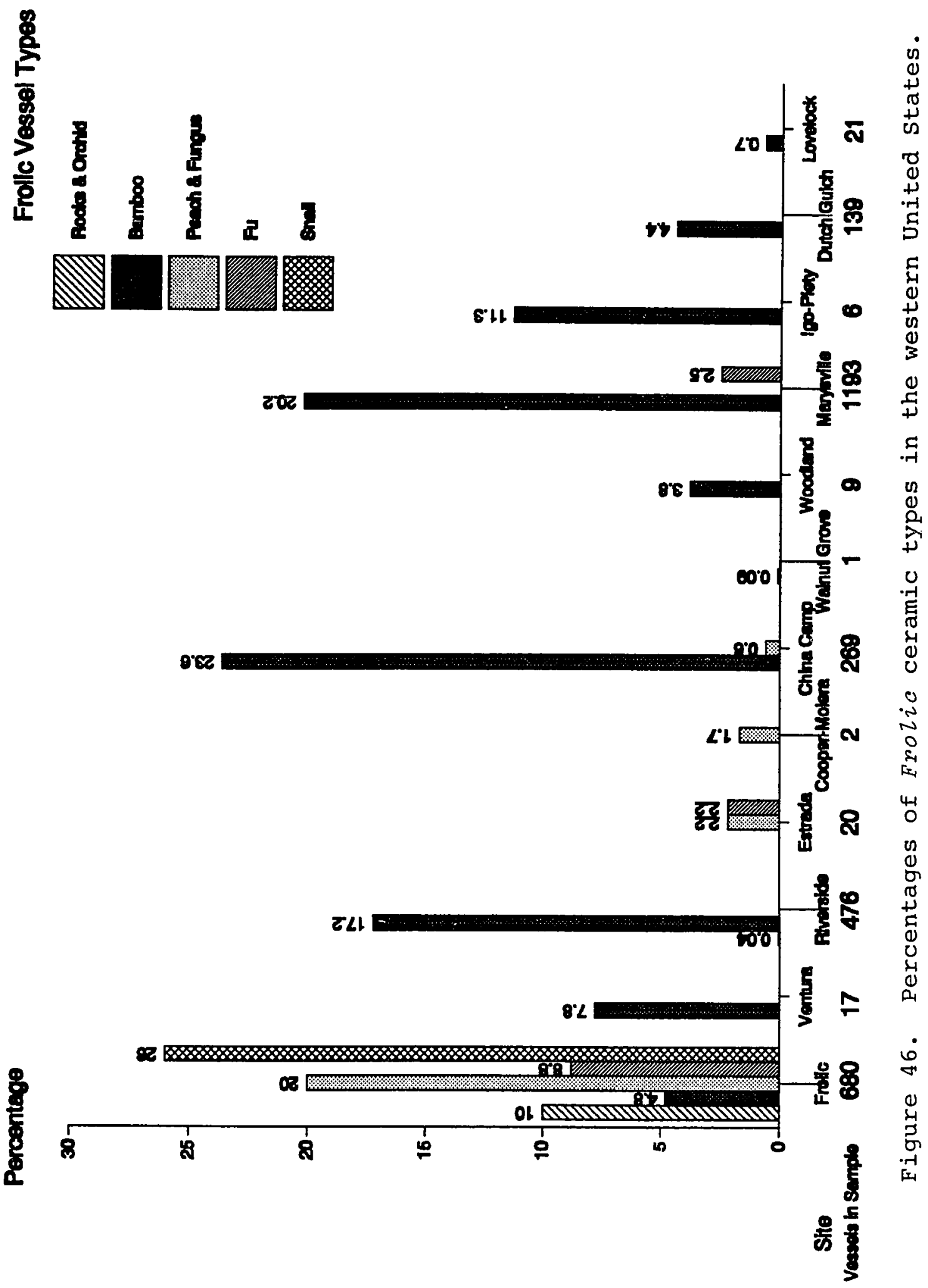


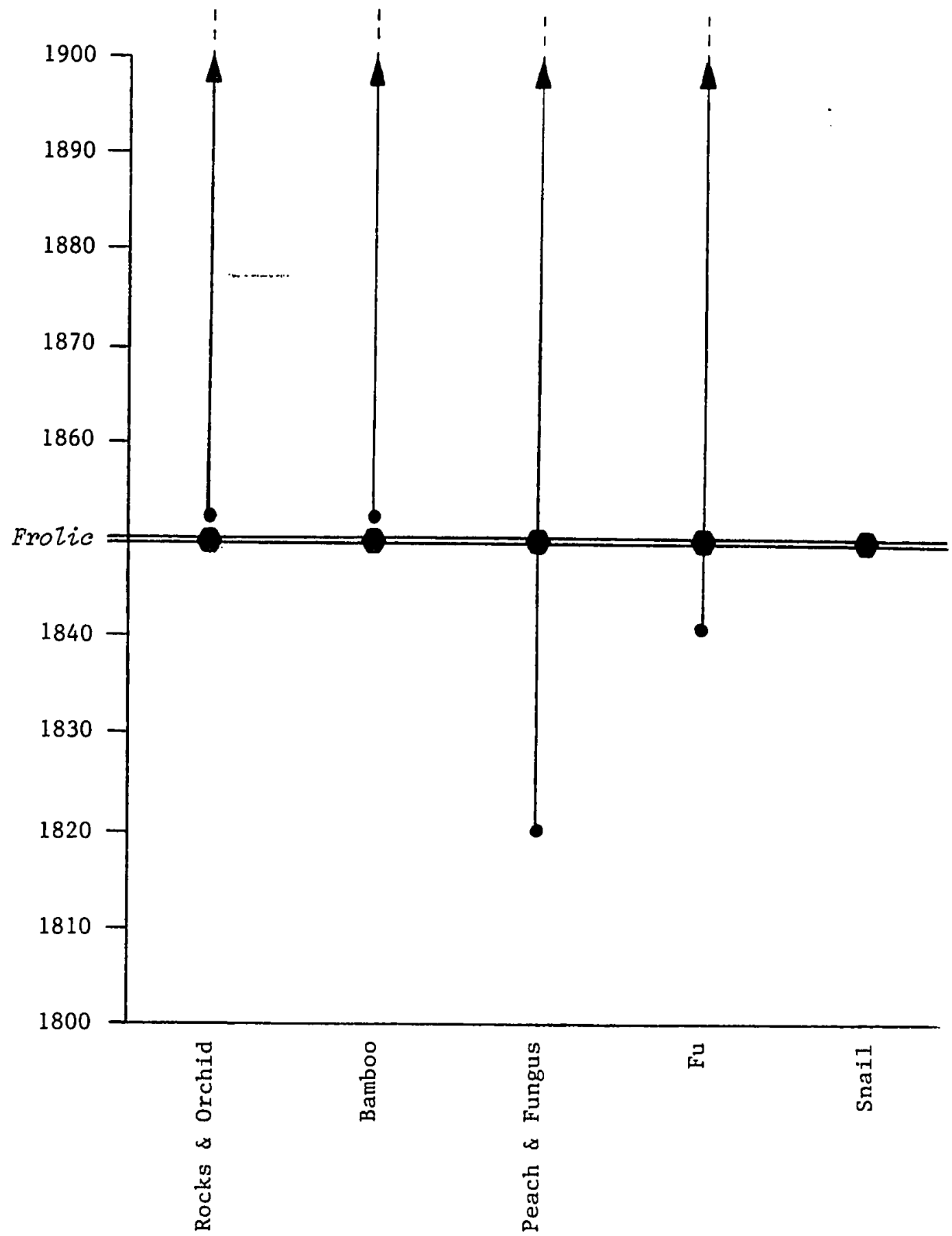

Figure 47. Relative chronology of five Frolic ware types from California and Arizona sites. 
APPENDICES

165 
Appendix A

CHRONOLOGY OF CHINESE DYNASTIES

\begin{tabular}{|c|c|c|}
\hline \multicolumn{3}{|l|}{ Song Dynasty 960-1279 } \\
\hline \multicolumn{3}{|l|}{ Yuan Dynasty 1280-1368 } \\
\hline Ming Dynasty 1368-1644 & $\begin{array}{r}\text { Hongwu } \\
\text { Xuande } \\
\text { Chenghua } \\
\text { Hongzhi } \\
\text { Zhengde } \\
\text { Jiajing } \\
\text { Longqing } \\
\text { Wanli } \\
\text { Tianqi } \\
\text { Chongzhen }\end{array}$ & $\begin{array}{l}1368-1398 \\
1426-1435 \\
1465-1487 \\
1488-1505 \\
1506-1521 \\
1522-1566 \\
1567-1572 \\
1573-1620 \\
1621-1627 \\
1628-1644\end{array}$ \\
\hline Qing Dynasty 1644-1911 & $\begin{array}{r}\text { Shunzhi } \\
\text { Kangxi } \\
\text { Yongzheng } \\
\text { Qianlong } \\
\text { Jiaqing } \\
\text { Daoguang } \\
\text { Xianfeng } \\
\text { Tongzhi } \\
\text { Guangxu } \\
\text { Xuantong }\end{array}$ & $\begin{array}{l}1644-1661 \\
1662-1722 \\
1723-1735 \\
1736-1795 \\
1796-1820 \\
1821-1850 \\
1851-1861 \\
1862-1874 \\
1875-1908 \\
1909-1911\end{array}$ \\
\hline Republic Period 1912 . & & \\
\hline
\end{tabular}




\section{Appendix B}

\section{GLOSSARY}

Bisque

Catherine wheel

Cavetto

Kaolin

Hong

Knop

Levigate

Ling zhih (Ling zhi)

Porcelaneous stoneware
Unglazed, fired clay ware.

A representation of a wheel with spikes projecting from the rim; frequently used term to describe a circular or whirl pattern usually found in the well of a bowl or saucer-plate.

A concave curve that is approximately a quarter circle; that part of the interior of a vessel which extends from the well to the rim.

Derived from a combination of the Chinese words $k a o$ (high) and ling (ridge or hill); a pure, white clay that, when combined with other materials, is highly plastic and can be fired at high temperatures.

Chinese merchant guild, formed in $\mathbf{1 7 2 0}$ to control foreign trade and insure profits from foreign shipping.

Molded form which appears as an ornamental handle on vases and covered vessels; also called the Dog of Fo or Lion of Buddha.

The separation of fine material from coarser material by suspension in a liquid.

The sacred fungus and symbol of longevity.

Comprised of kaolin, feldspar and quartz, in varying quantities; a ceramic ware fired to a hard, clay body which resists abrasion under normal wear. The color can vary from near white to gray, depending upon the firing conditions and clay mix. 
Rocaille

Shoulder

Stacking ring

Tz'u

Underglaze

Well
A style of ornamentation developed in the 18th century and characterized by forms derived from the artificial rockwork or grottowork and pierced shellwork of the period.

That part of the outside wall of a vessel which corresponds to the lower curve of the cavetto; usually just above the footring.

A circular bisque band in the well of a vessel, left unglazed so that nested vessels will not stick together during firing.

Chinese term meaning high-fired ware, which includes stoneware and porcelain.

Pigments comprised of a mixture of water or other binding agents and oxides, applied directly to the unfired clay body prior to glazing.

The central, usually depressed portion of the inside bottom of a vessel. 
Appendix C

CATALOG OF VESSELS AND SHERDS

\begin{tabular}{|c|c|c|c|c|}
\hline \multicolumn{5}{|c|}{ Catalog of Rocks \& Orchid Type Vessels } \\
\hline $\begin{array}{l}\text { Base } \\
100 \% \\
\end{array}$ & $\begin{array}{l}\text { Base } \\
50 \%+ \\
\end{array}$ & $\begin{array}{l}\text { Basal } \\
\text { Sherd* }\end{array}$ & $\begin{array}{l}\text { Body } \\
\text { Sherd } \\
\end{array}$ & $\begin{array}{l}\text { Rim } \\
\text { Sherd } \\
\end{array}$ \\
\hline $\begin{array}{l}1-5 \\
3-22 \\
3-23 \\
3-25 \\
3-26 \\
3-116 \\
5-413 \\
5-414 \\
6-12 \\
9-1 \\
10-121 \\
10-122\end{array}$ & $\begin{array}{l}3-27 \\
3-30 \\
3-31^{* *} \\
8-3 \\
8-4 \\
8-5 \\
5-84 / 91 \\
5-272 / 273 \\
5-227 \\
5-278 \\
10-123 \\
10-124\end{array}$ & $\begin{array}{l}3-28 \\
3-29 \\
5-82 \\
5-83 \\
5-85 \\
5-86 \\
5-87 \\
5-88 \\
5-89 \\
5-90 \\
5-93 \\
5-95 \\
5-96 \\
5-97 \\
5-98 \\
5-275 \\
5-279 \\
5-280 \\
5-281 \\
5-415 \\
5-416 \\
5-417 \\
5-418 \\
6-11 \\
6-13 \\
6-14 \\
8-6 \\
8-7 \\
8-8 \\
8-9 \\
8-10 \\
8-11 \\
8-12 / 14 \\
8-13 \\
10-125\end{array}$ & $5-323$ & $\begin{array}{l}5-92 \\
5-94 \\
5-179 \\
5-274 \\
5-276 \\
5-282 \\
5-283 \\
5-284 \\
5-314 \\
5-317 \\
8-15\end{array}$ \\
\hline 12 & 12 & 35 & 1 & 11 \\
\hline $\begin{array}{cc}* & \text { Basa } \\
* * & 3-31 \\
& \text { well } \\
\end{array}$ & $\begin{array}{l}\text { consist o } \\
\text { omaly. } \\
\end{array}$ & $\begin{array}{l}\text { an } 50 \\
\text { ot ha }\end{array}$ & g/base & of the \\
\hline
\end{tabular}




\begin{tabular}{||l|l|l|l||}
\hline \multicolumn{4}{|c|}{ Catalog of Bamboo Type Vessels } \\
\hline Base 50\%+ & Basal Sherd & Body Sherd & Rim Sherd \\
\hline $3-16$ & $3-17 / 21$ & $5-100$ & $3-19$ \\
$3-18$ & $5-97$ & $5-167$ & $3-20$ \\
$5-99$ & $5-98$ & $5-184$ & $5-103$ \\
$5-410$ & $5-101$ & $5-187$ & $5-104$ \\
$5-411$ & $5-102$ & $5-196$ & $5-105$ \\
$5-412$ & $5-208$ & $5-389$ & $5-106$ \\
$8-24$ & & & $5-107$ \\
$8-25$ & & & $5-308$ \\
$10-126$ & & & $5-309$ \\
$11-4$ & & & $5-310$ \\
& & & $5-311$ \\
& & & $8-26$ \\
& & 6 & 13 \\
\hline 10 & 6 & & \\
\hline
\end{tabular}




\begin{tabular}{|c|c|c|c|c|c|}
\hline \multicolumn{6}{|c|}{ Catalog of Peach \& Fungus Type Vessels } \\
\hline $\begin{array}{l}\text { Base } \\
100 \%\end{array}$ & $\begin{array}{l}\text { Base } \\
50 \%+\end{array}$ & $\begin{array}{l}\text { Basal } \\
\text { Sherd }\end{array}$ & $\begin{array}{l}\text { Body } \\
\text { Sherd }\end{array}$ & $\begin{array}{l}\text { Body } \\
\text { Sherd }\end{array}$ & $\begin{array}{l}\text { Rim } \\
\text { Sherd }\end{array}$ \\
\hline $\begin{array}{l}2-21 \\
3-1 \\
3-2 \\
3-4 \\
3-5 \\
3-6 \\
3-7 \\
3-11 \\
3-13 \\
4-1 \\
4-2 \\
4-3 \\
4-4 \\
4-5 \\
4-6 \\
5-408 \\
6-1 \\
6-2 \\
8-16 \\
10-101 \\
10-102 \\
10-103 \\
10-104 \\
10-105 \\
10-106 \\
10-110 \\
11-5\end{array}$ & $\begin{array}{l}3-8 \\
3-9 \\
3-115 \\
5-108 \\
5-407 \\
6-3 \\
6-4 \\
8-17 \\
8-18 \\
10-107 \\
10-108 \\
10-109 \\
10-111 \\
10-112 \\
10-113 \\
11-1\end{array}$ & $\begin{array}{l}2-16 \\
3-10 \\
3-12 \\
3-124 \\
5-109 \\
5-110 \\
5-111 \\
5-112 \\
5-116 \\
5-123 \\
5-146 \\
5-237 \\
6-7 \\
6-5 \\
6-6 \\
6-10 \\
8-19 \\
8-20 \\
10-114 \\
10-115 \\
10-116 \\
10-117 \\
10-118 \\
10-119 \\
11-2\end{array}$ & $\begin{array}{l}3-59 \\
3-125 \\
3-126 \\
5-114 \\
5-115 \\
5-120 \\
5-160 \\
5-164 \\
5-166 \\
5-169 \\
5-171 \\
5-172 \\
5-176 \\
5-187 \\
5-189 \\
5-190 \\
5-191 \\
5-194 \\
5-195 \\
5-197 \\
5-198 \\
5-200 \\
5-203 \\
5-204 \\
5-205 \\
5-271 \\
5-286 \\
5-287 \\
5-290 / 289 \\
5-291 \\
5-292 \\
5-293 \\
5-294 \\
5-295 \\
5-296 \\
5-297 \\
5-298 \\
5-299 \\
5\end{array}$ & $\begin{array}{l}5-300 \\
5-301 \\
5-318 \\
5-319 \\
5-320 \\
5-321 \\
5-322 \\
5-324 \\
5-327 \\
5-328 \\
6-9 \\
6-33 \\
8-21 \\
8-22 \\
10-120\end{array}$ & $\begin{array}{l}3-14 \\
5-113 \\
5-117 \\
5-118 \\
5-119 \\
5-121 \\
5-122 \\
5-124 \\
5-175 \\
5-178 \\
5-181 \\
5-186 \\
5-188 \\
5-201 \\
5-302 \\
5-303 \\
5-304 \\
5-305 \\
5-306 \\
5-307 \\
6-8 \\
6-37 \\
8-23\end{array}$ \\
\hline 28 & 16 & 25 & 38 & 15 & 23 \\
\hline
\end{tabular}




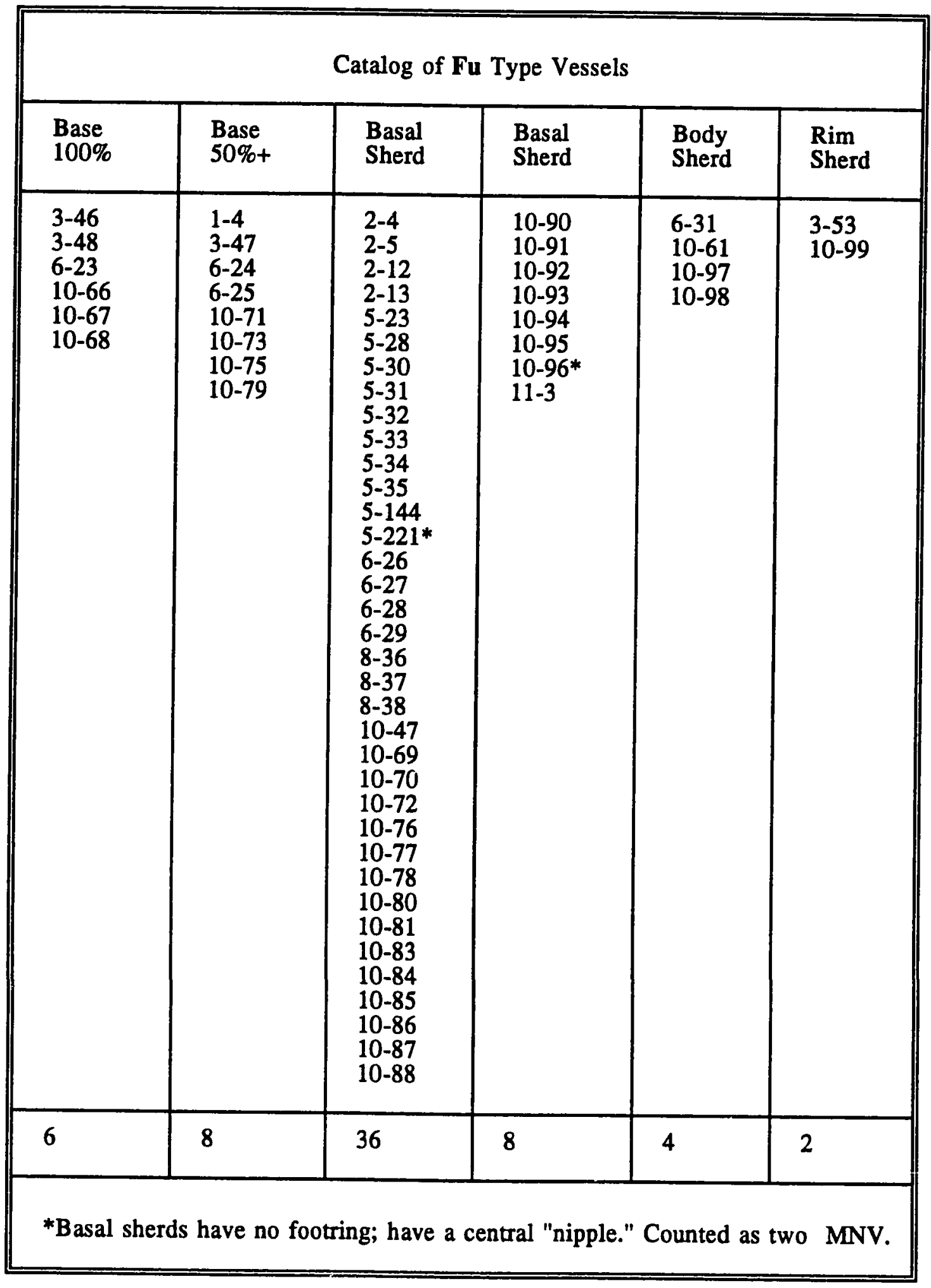




\begin{tabular}{|c|c|c|c|c|}
\hline \multicolumn{5}{|c|}{ Catalog of Snail Variety A Vessels } \\
\hline $\begin{array}{l}\text { Base } \\
100 \%\end{array}$ & $\begin{array}{l}\text { Base } \\
50 \%+\end{array}$ & $\begin{array}{l}\text { Basal } \\
\text { Sherd }\end{array}$ & $\begin{array}{l}\text { Body } \\
\text { Sherd }\end{array}$ & $\begin{array}{l}\text { Rim } \\
\text { Sherd }\end{array}$ \\
\hline $\begin{array}{l}3-32 \\
3-33 \\
3-35 / 10-29 \\
3-137 \\
10-14\end{array}$ & $\begin{array}{l}2-17 \\
3-36 \\
5-1 \\
5-3 \\
10-7 \\
10-46\end{array}$ & $\begin{array}{l}--- \\
--- \\
--- \\
-- \\
--- \\
---\end{array}$ & $\begin{array}{l}--- \\
--- \\
--- \\
--- \\
---\end{array}$ & $\begin{array}{l}3-42 \\
3-43 \\
3-45 \\
5-47 \\
5-49 \\
5-50 \\
5-52 \\
5-53 \\
5-54 \\
5-64 \\
5-67 \\
5-70 \\
5-71 \\
5-79 \\
5-312 \\
5-313 \\
10-65\end{array}$ \\
\hline 5 & 6 & 0 & 0 & 17 \\
\hline
\end{tabular}




\begin{tabular}{|c|c|c|c|c|}
\hline \multicolumn{5}{|c|}{ Catalog of Snail Variety B Vessels } \\
\hline $\begin{array}{l}\text { Base } \\
100 \%\end{array}$ & $\begin{array}{l}\text { Base } \\
50 \%+\end{array}$ & $\begin{array}{l}\text { Basal } \\
\text { Sherd }\end{array}$ & $\begin{array}{l}\text { Body } \\
\text { Sherd }\end{array}$ & $\begin{array}{l}\text { Rim } \\
\text { Sherd }\end{array}$ \\
\hline $6-16$ & $\begin{array}{l}5-2 \\
5-8 \\
5-11 \\
5-12 \\
5-40 \\
5-285 \\
6-19 \\
10-23 \\
10-26\end{array}$ & $\begin{array}{l}--- \\
--- \\
--- \\
--- \\
--- \\
--- \\
---\end{array}$ & $\begin{array}{l}--- \\
--- \\
--- \\
-- \\
-- \\
--- \\
--- \\
---\end{array}$ & $\begin{array}{l}--- \\
--- \\
--- \\
--- \\
--- \\
--- \\
--- \\
--\end{array}$ \\
\hline 1 & 9 & 0 & 0 & 0 \\
\hline
\end{tabular}




\begin{tabular}{||l|l|l|l|l||}
\hline \multicolumn{5}{|c||}{ Catalog of Snail Variety C } \\
\hline Base \\
$100 \%$ & $\begin{array}{l}\text { Base } \\
50 \%+\end{array}$ & $\begin{array}{l}\text { Basal } \\
\text { Sherd }\end{array}$ & $\begin{array}{l}\text { Body } \\
\text { Sherd }\end{array}$ & $\begin{array}{l}\text { Rim } \\
\text { Sherd }\end{array}$ \\
\hline $5-406$ & $2-8$ & -- & -- & --- \\
$10-4$ & $2-14$ & -- & --- \\
& $5-4 / 59 / 69 / 236$ & -- & --- \\
& $5-10 / 234$ & -- & --- \\
& $10-24$ \\
& $10-25$ & --- & --- \\
& $10-31$ & --- & --- \\
\hline 2 & & --- & -- & -- \\
\hline
\end{tabular}




\begin{tabular}{||l|l|l|l|l||}
\hline \multicolumn{5}{|c||}{ Catalog of Snail Variety D Vessels } \\
\hline Base \\
$100 \%$ & $\begin{array}{l}\text { Base } \\
50 \%+\end{array}$ & $\begin{array}{l}\text { Basal } \\
\text { Sherd }\end{array}$ & $\begin{array}{l}\text { Body } \\
\text { Sherd }\end{array}$ & $\begin{array}{l}\text { Rim } \\
\text { Sherd }\end{array}$ \\
\hline $3-34$ & $2-18$ & $3-37$ & -- & --- \\
$3-38$ & $5-9$ & $5-13$ & -- & -- \\
$3-39$ & $8-27$ & $5-16$ & --- & --- \\
$10-5$ & & $5-42$ & $-\cdots$ & --- \\
$10-12$ & & $8-28$ & --- & --- \\
$10-13$ & & & --- & 0 \\
$10-18$ & & & 0 & - \\
\hline 7 & 3 & 5 & & - \\
\hline
\end{tabular}




\begin{tabular}{|c|c|c|c|c|}
\hline \multicolumn{5}{|c|}{ Catalog of Snail Variety E Vessels } \\
\hline $\begin{array}{l}\text { Base } \\
100 \%\end{array}$ & $\begin{array}{l}\text { Base } \\
50 \%+\end{array}$ & $\begin{array}{l}\text { Basal } \\
\text { Sherd }\end{array}$ & $\begin{array}{l}\text { Body } \\
\text { Sherd }\end{array}$ & $\begin{array}{l}\text { Rim } \\
\text { Sherd }\end{array}$ \\
\hline $\begin{array}{l}3-49 \\
4-7 \\
10-2 \\
10-3 \\
10-15 \\
10-16 \\
10-17\end{array}$ & $\begin{array}{l}2-1 \\
2-2 \\
2-7 \\
2-9 \\
3-50 \\
3-52 \\
5-6 \\
5-20 \\
5-22 \\
5-26 \\
5-36 \\
5-39 \\
5-55 \\
6-15 \\
6-17 \\
6-18 \\
8-31 \\
10-6 \\
10-10 \\
10-11 \\
10-19 \\
10-22 \\
10-27 \\
10-28 \\
10-30 \\
10-32 \\
10-33 \\
10-35 \\
10-36 \\
10-39 \\
10-41 \\
10-51 \\
10-59\end{array}$ & $\begin{array}{l}5-5 \\
5-17 \\
5-18 \\
5-24 \\
5-25 \\
5-27 \\
5-37 \\
5-38 \\
5-41 \\
6-20 \\
8-29 \\
8-30 \\
10-8 \\
10-9 \\
10-20 \\
10-21 \\
10-34 \\
10-37 \\
10-38 \\
10-40 \\
10-42 \\
10-43 \\
10-44 \\
10-45 \\
10-50 \\
10-54 \\
10-55 \\
10-57 \\
10-58 \\
11-6 \\
11-8\end{array}$ & $\begin{array}{c}--- \\
--- \\
--- \\
--- \\
--- \\
--- \\
--- \\
---\end{array}$ & $\begin{array}{c}--- \\
-- \\
--- \\
-- \\
--- \\
-- \\
-- \\
-- \\
--\end{array}$ \\
\hline 7 & 33 & 31 & 0 & 0 \\
\hline
\end{tabular}




\begin{tabular}{|c|c|c|c|c|c|}
\hline \multicolumn{6}{|c|}{ Catalog of Snail Vessels - Variety Unknown } \\
\hline $\begin{array}{l}\text { Vessel } \\
\text { Type }\end{array}$ & $\begin{array}{l}\text { Base } \\
100 \%\end{array}$ & $\begin{array}{l}\text { Base } \\
50 \%+\end{array}$ & $\begin{array}{l}\text { Basal } \\
\text { Sherd }\end{array}$ & $\begin{array}{l}\text { Body } \\
\text { Sherd }\end{array}$ & $\begin{array}{l}\text { Rim } \\
\text { Sherd }\end{array}$ \\
\hline $\begin{array}{l}\text { Variety } \\
\text { A, B or C }\end{array}$ & $\begin{array}{l}10-1 \\
-- \\
-- \\
-- \\
-- \\
-- \\
-- \\
-- \\
-- \\
-- \\
-- \\
-- \\
-- \\
-- \\
-- \\
-- \\
-- \\
--\end{array}$ & 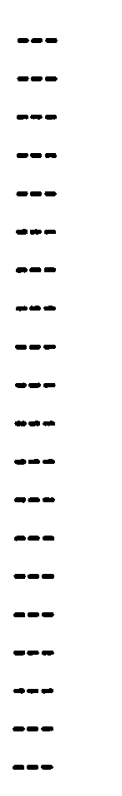 & $\begin{array}{l}3-40 \\
3-41 \\
5-7 \\
5-14 \\
5-15 \\
5-19 \\
5-21 \\
5-43 \\
5-44 \\
5-78 \\
5-81 \\
5-142 \\
5-145 \\
10-47 \\
10-48 \\
10-49 \\
10-52 \\
10-53 \\
10-56 \\
11-7\end{array}$ & 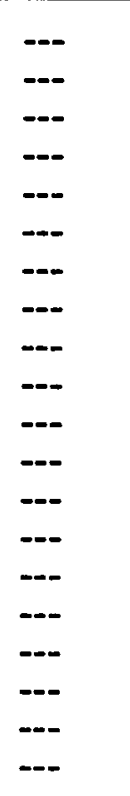 & 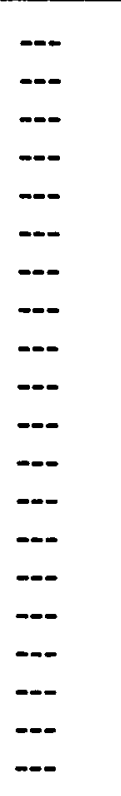 \\
\hline $\begin{array}{l}\text { Variety } \\
\text { A,B,C,D, } \\
\mathrm{E}\end{array}$ & \begin{tabular}{l}
--- \\
-- \\
-- \\
-- \\
$\cdots-$ \\
-- \\
-- \\
\hdashline- \\
-- \\
-- \\
--
\end{tabular} & $\begin{array}{l}5-143 \\
--- \\
--- \\
--- \\
--- \\
-- \\
-- \\
-- \\
--\end{array}$ & $\begin{array}{l}--- \\
--. \\
--. \\
-- \\
--. \\
-- \\
-- \\
-- \\
-- \\
--\end{array}$ & $\begin{array}{l}3-60 \\
5-57 \\
5-65 \\
5-68 \\
5-155 \\
5-159 \\
5-192 \\
6-21 \\
6-22 \\
10-62 \\
11-10\end{array}$ & $\begin{array}{l}--- \\
--- \\
-- \\
--- \\
-- \\
-- \\
-- \\
-- \\
-- \\
--\end{array}$ \\
\hline & 1 & 1 & 20 & 11 & 0 \\
\hline
\end{tabular}




\begin{tabular}{|c|c|c|c|c|c|}
\hline \multicolumn{6}{|c|}{ Catalog of Snail Vessels - Variety Unknown (Cont.) } \\
\hline $\begin{array}{l}\text { Vessel } \\
\text { Type }\end{array}$ & $\begin{array}{l}\text { Base } \\
100 \%\end{array}$ & $\begin{array}{l}\text { Base } \\
50 \%+\end{array}$ & $\begin{array}{l}\text { Basal } \\
\text { Sherd }\end{array}$ & $\begin{array}{l}\text { Body } \\
\text { Sherd }\end{array}$ & $\begin{array}{l}\text { Rim } \\
\text { Sherd }\end{array}$ \\
\hline $\begin{array}{l}\text { Variety } \\
\text { A,B,C,D, } \\
\text { E }\end{array}$ & 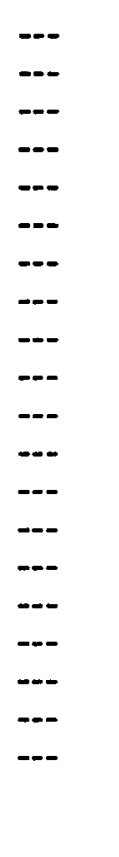 & $\begin{array}{c}-- \\
--- \\
--- \\
--- \\
--- \\
--- \\
--- \\
--- \\
--- \\
-- \\
-- \\
-- \\
-- \\
--- \\
--- \\
--- \\
-- \\
-- \\
--- \\
--\end{array}$ & 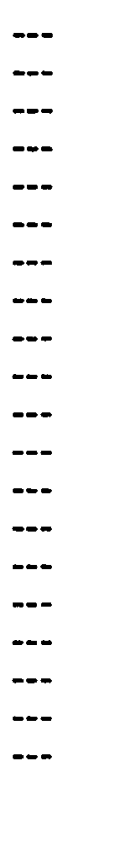 & 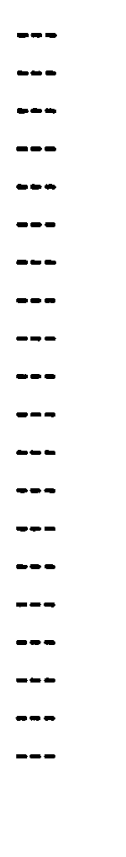 & $\begin{array}{l}3-44 \\
5-45 \\
5-46 \\
5-48 \\
5-60 \\
5-61 \\
5-62 \\
5-66 \\
5-72 \\
5-74 \\
5-75 \\
5-77 \\
5-80 \\
5-152 \\
5-153 \\
5-157 \\
5-158 \\
5-185 \\
5-315 \\
5-316 \\
8-32 \\
11-9\end{array}$ \\
\hline & 0 & 0 & 0 & 0 & 22 \\
\hline
\end{tabular}




\begin{tabular}{|c|c|c|c|c|}
\hline \multicolumn{5}{|c|}{$\begin{array}{l}\text { Catalog of Two Minor Types and } \\
\text { Unidentified Sherds of Five Major Types }\end{array}$} \\
\hline $\begin{array}{l}\text { Vessel } \\
\text { Type }\end{array}$ & MNV & $\begin{array}{l}\text { Basal } \\
\text { Sherd } \\
\end{array}$ & $\begin{array}{l}\text { Body } \\
\text { Sherd }\end{array}$ & $\begin{array}{l}\text { Rim } \\
\text { Sherd }\end{array}$ \\
\hline $\begin{array}{l}\text { Unidentifiable } \\
\text { sherds of: } \\
\text { Rocks \& } \\
\text { Orchid, } \\
\text { Bamboo, Peach } \\
\text { \& Fungus, Fu, } \\
\text { and Snail }\end{array}$ & $3-117$ & $\begin{array}{l}5-168 \\
5-186 \\
5-193 \\
5-329 \\
6-30 \\
8-33 \\
8-34 \\
10-134 \\
10-135 \\
10-136 \\
10-137 \\
10-138 \\
10-139 \\
10-140 \\
10-141 \\
10-142 \\
10-143 \\
10-144 \\
10-145 \\
10-146\end{array}$ & $\begin{array}{l}3-128(9)^{*} \\
5-28 \\
5-33(54)^{*} \\
5-51 \\
5-63 \\
5-73 \\
5-147 \\
5-150 \\
5-151 \\
5-154 \\
5-156 \\
5-161 \\
5-162 \\
5-165 \\
5-174 \\
5-175 \\
5-177 \\
5-180 \\
5-182 \\
5-202 \\
5-207 \\
5-209 \\
5-210 \\
5-211 \\
5-212 \\
5-125 \\
5-326 \\
5-330 \\
6-32 \\
6-34 \\
8-35 \\
10-60 \\
10-63 \\
10-64\end{array}$ & $\begin{array}{l}2-123 \\
2-127(3)^{*} \\
5-56 \\
5-58 \\
5-148 \\
5-149 \\
5-163 \\
5-170 \\
5-183 \\
5-199 \\
5-220 \\
5-331(21)^{*}\end{array}$ \\
\hline \multirow[t]{2}{*}{ Ginger Jar } & $3-55 / 56$ & $\begin{array}{l}8-1 \\
10-127 \\
10-128\end{array}$ & $5-219$ & \\
\hline & 2 & 23 & $35+(63)$ & $12+(24)$ \\
\hline
\end{tabular}

* Number in parenthesis represents total number of pieces included in that catalog number. 


\begin{tabular}{|c|c|c|c|c|}
\hline \multicolumn{5}{|c|}{ Catalog of Miscellaneous Sherds } \\
\hline Sherds & Misc. & $\begin{array}{l}\text { Basal } \\
\text { Sherd }\end{array}$ & $\begin{array}{l}\text { Body } \\
\text { Sherd }\end{array}$ & $\begin{array}{l}\text { Rim } \\
\text { Sherd }\end{array}$ \\
\hline $\begin{array}{l}\text { Misc. blue-and- } \\
\text { white }\end{array}$ & $\begin{array}{l}3-51^{*} \\
\text { (base) } \\
3-54^{*} \\
\text { (base) }\end{array}$ & \multirow[b]{4}{*}{$\begin{array}{l}3-62 \\
7-1\end{array}$} & $\begin{array}{l}3-58 \\
5-217 \\
8-2 \\
10-148\end{array}$ & $\begin{array}{l}5-339 \\
10-147\end{array}$ \\
\hline $\begin{array}{l}\text { Brown-glazed ware } \\
\text { Doorknob }\end{array}$ & $7-2$ & & \multirow[b]{3}{*}{$\begin{array}{l}3-63 \\
5-218 \\
7-3 \\
7-4\end{array}$} & \multirow{7}{*}{$\begin{array}{l}5-338 \\
10-130\end{array}$} \\
\hline Knop-handle & $\begin{array}{l}5-333 \\
5-334 \\
5-335 \\
5-336\end{array}$ & & & \\
\hline Unidentified & & & & \\
\hline $\begin{array}{l}\text { Miscellaneous } \\
\text { (unidentified) }\end{array}$ & 3-64 & $\begin{array}{l}3-61 \\
10-131\end{array}$ & $\begin{array}{l}5-222 \\
5-223 \\
5-224 \\
5-225 \\
5-341 \\
5-342 \\
6-35 \\
6-36\end{array}$ & \\
\hline Finial & $5-340$ & & & \\
\hline Lid & $5-337$ & & & \\
\hline Teapot Spout & $1-6$ & & & \\
\hline & 11 & 4 & 16 & 4 \\
\hline
\end{tabular}

* These are included in total MNV (178) in Table 2. 


\begin{tabular}{||l|l|l|l||}
\hline \multicolumn{4}{|c|}{ Catalog of Miscellaneous Vessels and Sherds (Cont.) } \\
\hline Vessel & Basal & Body & Rim \\
Type & Sherd & Sherd & Sherd \\
\hline English & $3-69$ & $3-66 / 70 / 3-68$ & $1-7$ \\
Staffordshire & $5-127$ & $5-128$ & $3-65$ \\
& $5-129$ & $5-135$ & $3-67$ \\
& $5-132$ & $5-137$ & $3-72$ \\
& $5-133$ & $5-138$ & $3-73$ \\
& $5-136$ & $5-139$ & $5-130$ \\
& $5-141$ & $5-140$ & $5-131$ \\
& $10-129$ & $5-338$ & $5-134$ \\
& & $10-132$ & $12-1 / 12-2$ \\
& & $10-133$ & \\
& & $12-3$ & \\
\hline & & & 9 \\
\hline
\end{tabular}

